INFORMAL REPORT

\title{
Monte Carlo Photon Codes: MCG and MCP
}

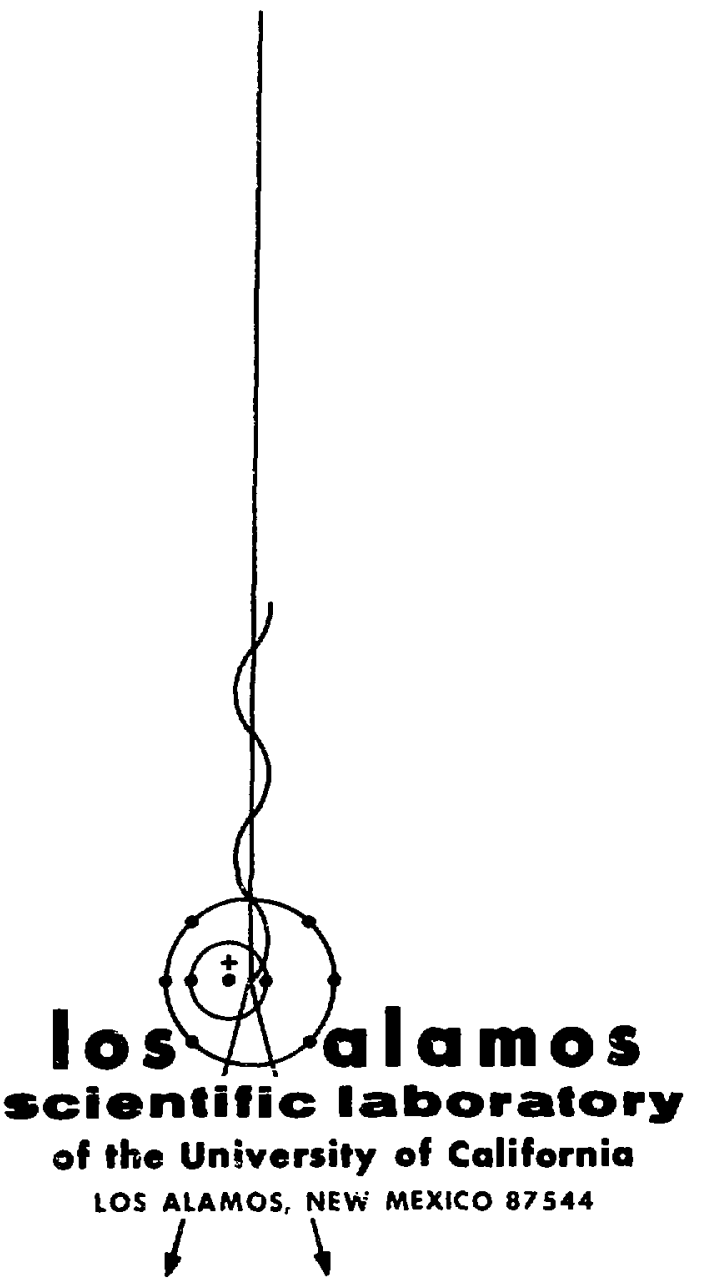


This report was prepared as an account of work sponsored by the United States Government. Neither the United States nor the United States Atomic Energy Commission, nor any of their employees, nor any of their contractors, subcontractors, or their employees, makes any warranty. express or implied, or assumes any legal liability or responsibility for the accuracy, completeness or usefulness of any information, apparatus, product or process disclosed. or represents that its use would not infringe privately owned rights.

In the interest of prompt distribution, this LAMS report was not edited by the Technical information staft.

Printed in the United States of America. Avalthille from

National Technieal Intormstion Service

U. S. Department ol Commerce 5285 Port Royal Road

Springtield Virginia 22151

Price: Prinied Copy \$3.00: Mieroliche S0.95 
LA-5157-MS

informal Rerrort

UC. 32 and UC. 34

ISSUED: March 1973

\section{Monte Carlo Photon Codes: MCG and MCP}

by

E. D. Cashwell

J. R. Neergaard

C. J. Everett

R. G. Schrandt

W. M. Taylor

G. D. Turner

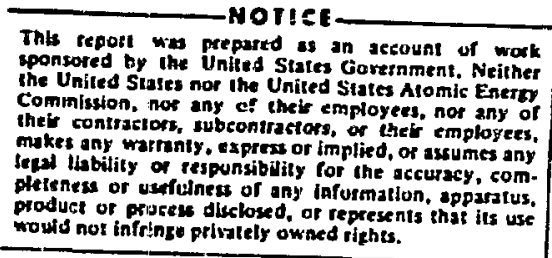

roonsored the prepured is an account of work the Unired Siases nor ing Coministion, no any

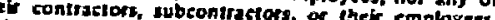
ersumes any Dlets ness or visfliness or any infurenation, proutes of proress dicclosed, of represents that its use wow not iniringe privately owned rights. 
MONTE CARLO PEOTUN CODES: MCG AND MCP

by

E. D. Cashrell

J. R. Neergaard

c. J. Everett

R. G. Schrandt

W. M. Taylor

G. D. Jurner

ABSTRACI

A description of the Monte Carlo photon codes, KCG ard MCP, 15 glves. Sinse these codes contain many features in comoll with the Monte Carlo neutron code MCN, which 13 deseribed in LA-4751, we concentrate on the detalls pecullar to processing phorone in each of these prograns. This report leans heavily on L-4751 and 1s 1ntended to be used in conjunction with it when dealing with a photon problen. The parts of the photon codes which are the same as in $\mathrm{KCN}$ are clearly indlcated.

In Part I, an account is given of MCG. Th1s code is suitable for aolving a ulde variety of gamea transport problems. The phyaical prosesses treated are palt production, Compton Bcatcering, and photoelectric absorption. The collifion routine ansuses photons w1th encrgies between $1 \mathrm{keV}$ and $100 \mathrm{MeV}$. The posalule cources, geometry, and output avallable to the user are described, together w1th the Monte Carlo methods and cross section date cuployed.

Part II descr 1bes MCP, which has a more sophtsticated Monte Cario colliston routine for phocons of energy 1 keV to $15 \mathrm{MeV}$ collidins with atoms of $2=1,2, \cdots, 94$ at reat. The routine takes account of Incoherent and coherent scattering factors, and of the possibility of fluorescent esission following photo-electric abeorption, as well as absorption in palr production with local eriasion of annihilation radiation.

In Part III, a saple probles is set up and zun using both KCG and HCP, with the cosplete computer liating diaplayed in each case.

\section{PART I}

MCS: A HONTE CARLO GAYA CODE FOR HTGH ENERCY PHOTON TRANSPORT

\section{A. IMTRODUCTION}

The Honte Carlo gatoa code MCS has any features in cosmon with the neutron code KCH, which is described In $2 A-4751 .^{2}$ in the 1ntereats of brevity. we will not describe in detall the featuren which sre the save in the two codes but ately puint out that they are identical, and we refer the reader to LA-4751 for the detalla.

setting up a problew for MCG is quite ofmilar to seteing up one for MCH, with only a feu differences renulting fros the altered colliaton routine 
for photons as well as from the slight wodffications of the output tall1es.

The untts used in MCG are the same as those used in MCN and are as follows:
1. Lengths in certimeters.
2. Times In shakes $\left(10^{-8} \mathrm{gec}\right)$.
3. Energies in MeV.
4. Atomic densities in units of $10^{24}$ atoirs/ $\mathrm{cm}^{3}$.
5. Cross aections in barns $\left(10^{-24} \mathrm{~cm}^{2}\right)$.

\section{B. GEOMETRY}

The three-dimensional geometry package in MCG Ia Identical to that in MCN. The code will handle apatial cells bounded by f1rst- and second-degree surfaces, as well as some fourth-degree surfaces (elliptical tor 1 ). The reader 18 strongly urged to read the description of the geometry in LA-4751, since the most comwon errors made in setting up a problem occur in specifying the geometry.

\section{COLLISION ROUTINE}

The physical processes treated are photoelectric effect, pair production, and compton scattering on free electrons (alternatively, the cade provides for Thomson scattering in place of compton scattering, at the option of the user). These are more fully described in the following.

Since the code is intended primarily for higher energy photons, the photoelectric effect is regarded as an absorption (without fluorescence), scattering (Compton) is on free electrons (wthout use of form factors), and the highly forward coherent scatering is 1gnored. Thus the total cross section $\sigma_{t}$ is regarded as the sum of three components.

$$
\sigma_{t}=\sigma_{p e}+\sigma_{p p}+\sigma_{s}
$$

(An alternative code, MCP, designed to incorporate low energy effects, is another of our family of Monte Carlo codes. This code deals with fluoreacent re-emission, 1n addition to coherent and Incoinerent scattering as influenced by the approprlate form factors cf. Part II.)

1. Cross Sections. The Howerton Photon Interaction Library in ENDF/B forwet (Ref: UCRL-50400, Vol. VI) was the source of cross sections used in the code. The lacter ylelds tables of values of $\sigma_{p e}^{1}(z), \sigma_{p p}^{1}(z), \sigma_{s}^{1}(z)$, and $\sigma_{t}^{1}(z)$ for elements with the atomic numbers $z=1,2, \cdots, 83,86,90,92$, and 94 at a comonon sequence of 166 energles $E_{i}$, $1=1,2, \cdots, 166$. These energles 1nclude the photoelectric edges above $10 \mathrm{keV}$ of all elements propided for and were otherwise so chosen that 11near interpolacton glelds good accuracy at interzediate points. Always consecutive energy values are opaced so that the change in energy is $10 \%$ or less.

An infiation code prepares, for each material region in the problem, a single list of macroscopic total cross sections $\Sigma_{t}^{1}$ and required probabilities. Th1s $1 \mathrm{~s}$ a simplification allowed by the use of an $=$ zergy mesh comon to all elements $z$, and 1 t allows considerable aning in machine time for problems Involving highly composite media.

2. Photoelectric Effect. This is treated as an absorption, with a corresponding reduction in the phocon welght $W$, and hence does not result in the Ioss of a particle history. On every coillston, the weight $W \sigma_{p e} / \sigma_{t}$ and exergy EW $\sigma_{p e} / r_{c}$ are tallied In the appropriate bins. The non-captured weight $W\left(I-\sigma_{p e} / \sigma_{z}\right)$ is then forced to suffer either pair production or compton scattering with the proper deprindent probabilities.

3. Pair Production. In a colliston resulting in pair production (probability $\sigma_{p p} /\left(\sigma_{t}-\sigma_{p e}\right)$ ), It is assued that the kinetic energy $\mathrm{W}(\mathrm{E}-1.022) \mathrm{MeV}$ of the electron-position palr produced is deposited as thermal energy at the time and point, with footropic production of one gamms of energy $0.511 \mathrm{MeV}$, and weigit $2 \mathrm{~W}$, which 18 followed further.

4. Compton Scattering. The alternative to pair production (when both are posaible) 18 Compton scattering on a free electron, with probability $\sigma_{s} /\left(\sigma_{t}-\sigma_{p e}\right)$. In the event of such a colliston, the objective $1 \mathrm{~s}$ to determine the energy $1 \mathrm{~s}^{\prime \prime}$ of the scattered photon, and $\mu=\cos \theta$ for the angle $\theta$ af deflection from the line of flight. This ylelds at once the energy $W\left(E-E^{\prime}\right)$ deposited at the point of collision and the new direction of the scattered photon.

The differential cross section for the process Ia given by the Klein-Nishina formula

$K(\alpha, \mu) d_{i}=\pi r_{0}^{2}\left(\alpha^{-} / \alpha\right)^{2}\left(\alpha^{-} / \alpha+\alpha / \alpha^{-}+\mu^{2}-I\right) d \mu$, 
where - 18 the classical electron radius, $\alpha$ and $\alpha$ are the Incident and final photon energies in units of $0.511 \mathrm{MeV}\left(\alpha=\mathrm{E} /\left(\mathrm{mc}^{2}\right)\right.$, where to $1 \mathrm{~s}$ the mass of the electron and $c$ is the speed of light), and

$$
\alpha^{-}=\alpha /[1+\alpha(1-\mu)]
$$

Changing variables from $\mu$ to $x=1 /[1+\alpha(1-\mu)]$ on $\xi \equiv(1+2 \alpha)^{-1}<x<1$, one finds the probability density function for $x$ to be

$$
P(x)=B(x) / G(E)
$$

where $g(x)=x+x^{-1}+\mu^{2}-1$,

$$
\mu=1+\alpha^{-1}-(\alpha x)^{-1}
$$

and $G(x)=\int_{x}^{1} g(x) d x$

Thus, a random number $r$ determines $x$ by the implict relation

$$
r=G(x) / G(\xi)
$$

and consequently the required $\mu=1+\alpha^{-1}-(\alpha x)^{-!}$ and $a^{\prime}=0 x, E^{\prime}=0.511 a^{\prime}$.

An accurate epproximation ${ }^{2,3}$ for the inverse $x=H(y)$ of the function $y=G(x)$ allows rapid determination of $x=H[r G(\xi)]$, and this is now used in place of earlier methods.

5. Thomsinu scatterlag. One may optionally choose Thomson scattering it: place of the KleinNishina scactering function. Here the photon scatters with the probability denstey function in $\mu$ given by

$$
P(i) d \mu=\frac{3}{\delta}\left(1+\mu^{2}\right) d \mu
$$

wth no loss in energy. If a table of values for $\mu_{1} 18$ stored, where

$$
\frac{1}{N}=\frac{3}{8} \int_{\mu_{1}}^{1}\left(1+\mu^{2}\right) d \mu, 1=0,1, \cdots, N,
$$

then by choosing the integer 1 randornly on 1 ts range yields $N$ equally likely discrete scattering cosines $\mu_{1}$. In the present code $N=128$ (a power of two 15 used because of the ease of selecting 1 on a binary machine). One may, if moze accurac; is desired, Inearly interpolate between these equally likely values of $\mu_{1}$ but the present code does not Include this feature.

\section{ESTTMATION OF ERRORS}

The error analysis in MCG is Identical to that in $\mathrm{KCN}$, and we refer the reader to Sec. IV of LA-4751. In brief, for the tallies printed out, the code gives the relative error in the quantity scored, defined as the ratio of one standard deviation to the sample sean.

\section{E. SAMPLING TECHRIQUES}

The discussion In MCN carries over verbatim to HCG, with the same options avallable in the latt code.

Standard Tallies. Same as in MCN, with the same definitions used for currents and fluxes as in the neutron code. (The reader accustomed to the use of other terns such as $f 1 u x$ and mean intengit for what we call current and flux, respectively, should take careful note of the fact that we are using terminology ccmonly used in neutron transport theory.)

\section{F. EXECUTION OF HONTE CARLO PROGRAMS}

(In the following, much of the description for MCE is the same as for MCN--simply substitute MCG for MCN, and MCGI, the indtiation code, for the corseaponding neutron inftiation code, MCNI.) We shall 11st below the photon programs corresponding to those 11sted in LA-4751. When they are Identical, except for the obvious changes mencloned above, we sinali siaply indicate by the words "same as in "ACN".

1. Intitiation. Saze as in MCN.

2. Running. Sare as in $\mathrm{MCN}$, except that the run card has a different format. Nev the 2nd entry on the run card is weight $\mathrm{WR}$, and the 8 th entry (the run card in MCN has only 7 entries) is a welght WC < WR. (Both WR and WC are set by the user, subfect to the condition WR $>W C$ ). When the wefght $N$ of a photon has $w<$ [WC - I (source) ! II (n) -- where $I$ (source) Is the IEportance of the source reglon and I (n) 1 the importance of cell $n$ where the photon 
Is losated -- then if a random number

$r<W /[W R$ - I(source)/I(n)], the we1ght of the photon is taken to be [WR. I (source)]/I(n); otherwise the photon history is terminated.

3. File Menipulation. Same as in MCN.

4. Card Format. Same as in MCN,

5. Problem ID Card. Same as in MCN.

6. Cel1 Cards. Same as ir MCN.

7. Surface Carde. Same as in MCN.

8. Data Carda.

a. Cell Spectefication Cards. Cards to and

Y6 apply to MCG in exactly the same manner as in

MCN. The thermal specification cardis $R O, R l, \cdots$, Rn do not apply. The Y7 card In MCG speclfies the energy cutoff for each cell, below which energy the photon is dropped and not followed further.

b. Source Cards. Same as in MCN.

c. L Card. Does not apply to MCG.

d. Function Cards. The description in

LA-4751 of these cards carries over to MCG, with a couple of exceptions.

(1) The first exception is for $n=5$ :

Flux tally at points. In addition to the F5, E5, and T5 cards, an edditionel card, called the A card, has been added. This card contains the list of cello which contribute to the fluxes at the point detectors; that 1s, collisions in these cells, and only these cells, are allowed to contribute to the fium ai eath of the designated points. If the $A$ card is missing, collisions in all cells contribute to the fluxes at the point detectors.

(2) The second exception uccurs for $\mathfrak{n}=6$ : Capture cally in cells. Here MCG departs from MCN. MCG autonatically (without any action on the part of the user) gives for each cell in the problein the number (1.e., the welght) and energy of photons captured (from the photoelectric effect), the number and energy of phocons lost to energy cutoff, the number of photons creating a pait and the energy lost in the process, and the energy lost in Compton scattering collibions.

e. DO Card. This section does not apply. A DO card in MCG means that Thomson scattering replaces Compton scattering. The energy cutoff in MCG is given per cell and, as described above, appears on the $Y 7$ card.

i. Materlal Cards. The section applies to HCG If the nuclide cross section ID is replaced by the $Z$ (atomic number) of the element.

APPERDIX A

CONTROL CARD DECRS

Sazne as in MCN.

APPENDIX B

SOURCE SUBROUTIMRS

Same as In MCN, except for Sec. $\nabla$ - Random Number Generatora. The furction thats (KRN) Is replaced by $2 \times$ FRN (KRN) -1 . 


\section{A. INTRODUCTION}

The general photon code MCP has many features in common with the gamma code MCC, namely, the var1aty of sources, the output, the varlance reúcing techniques, and the general geometry routine. In fact, the two codes are virtually identical to use. However, the collision subroutine in MCG was intended only for photons of relatively high energy, wath fluorescence and coherent scattering 1gnored, and incoherent scattering subject to the unmodiffed Klein-Nishina cross section for free electrons. ${ }^{4}$

The code MCP, for photons of energies $1 \mathrm{keV}$ to $15 \mathrm{MeV}$, contains a new collision routine, described below, providing for fluorescent emisston, and the modification of Thomson and RJein-Nishina differentlal cross sections by appropriace form factors which cake binding effects into account.

A 11brary tape (LT) has been prepared, incorporating all constants required by the collision code, for elements $z=1, \cdots, 94,1$ a form designed $l=$

- expedite computation.

\section{B. FREE PATH}

The LT contains, for each $Z$, a table of the logarithms $L_{1}(z)=$ en $E_{1}(z)$ of suitable energies, Including the photoelectric edges, and a matrix $L_{1}^{j}(z)=\ln \sigma_{1}^{j}(z)$, 11sting for $f=1,2,3,4$, the logs of corresponding cross sections (when the latter are nonzero) for incoherent ocattering, coherent scattering, photoelectric effect, and pair production, respectively. The recent compllation of data by Storm and Israel ${ }^{5}$ was used, for all 11sted energies $E_{1} \leqslant 15 \mathrm{MeV}$. In the case of scattering $(f=1,2)$ the cited total cross sections were obtained by numerical integration, based on the same form factors used in the Monte Carlo treatment of such collisions, and referred tc below.

In the collision code, a photon of energy $E$, starting from a point of a particular medium, has a free path

$$
\lambda=1 /\left[\sum_{z} N(z) \sum_{1}^{4} \sigma^{J}(z)\right] \text {, }
$$

where 2 runs over all elements present in the medium, N(z) is the corresponding numericai density, and $\sigma^{j}(z)$ is the cross section for process $\mathrm{J}$, each $\mathrm{log}-$ $\log$ interpolated to energy $E$. A random number $r$ on $(0,1)$ then deteralnes the (initinte medium) distance to collision, $d=-\lambda \ln r$; and the eventuality of escape from, or collision with1n, the current region, follows from the geometry routine of MCP.

In the event of collision, two random numbers, $r_{1}$ and $r_{2}$, serve to designate the element $z \mathrm{hit}$, and the process $f$ responsible. The former results from a cosparison of $r_{1} / \lambda$ with the partial $z$-sums obtalned above, and present is cire memory. The latter process $j$ is determined by a siatlar comparison of $r_{2} \sum_{1}^{4} \sigma^{j}(z)$ with the partial sums Involved, the individun $1 \sigma^{j}(z)$ being also retained from the $\lambda$ computation.

Note on Interpolation. Log-10g interpolation for the partial cross sections $\sigma$, at an energy $E$ between tabulated energies $E_{i-1}<E_{1}$, leads to the result

$$
\sigma^{j}=\left(\sigma_{1-1}^{j}\right)^{a}\left(\sigma_{1}^{j}\right)^{b}
$$

where $a=\left(\ln E_{1}-\ln E\right) /\left(\ln E_{1}-\ln E_{1-1}\right)$, $a+b=1, a, b>0$. It 1 s expedient to regard as the total cross section, and as the probability of process $j$ at energy $E$, the values of $\sigma$ and $\sigma^{j} / \sigma$, where $\sigma$ 1s the sum $\sum_{1}^{4} \sigma^{j}$ of the $\sigma^{j}$ so found, and not the $\log -\log$ interpolated value $\sigma^{\prime}$ of the totel cross section. For, the relation

$$
\begin{aligned}
\sigma=\sum_{j} \sigma^{j} & =\sum_{j}\left(\sigma_{1-1}^{j}\right)^{a}\left(\sigma_{1}^{j}\right)^{b} \leqslant\left(\sum_{j} \sigma_{1-1}^{j}\right)^{a} \\
& \times\left(\sum_{j} c_{1}^{j}\right)^{b}=\sigma^{-}
\end{aligned}
$$

Is an obvious consequence of Hölder's Inequality,

$$
\sum x_{j} y_{j}<\left(\sum x_{j}^{1 / a}\right)^{a}\left(\sum y_{j}^{1 / 2}\right)^{b},
$$


strict unless $\mathrm{y}_{j}^{1 / \mathrm{b}} \equiv \mathrm{kx}_{\mathrm{j}}^{1 / \mathrm{a}}$.

Hence, in practice one has $c<\sigma^{-}$, and use of $\sigma^{\prime}$ In place of $\sigma$ may lead to absurdities; e.g., pair product1on, determined above by default (after the other three processes are tested), would occur at ail energies $E \geqslant 1 \mathrm{keV}$.

This shows that adoption of log-10g interpolated partial cross sections is inconsistent with a log- $10 g$ interpolated total cross section.

\section{INCOHERENT SCATTERING}

The objective, in the event of such a process $(j=1)$, is to determine the angle $\theta$ of scattering from the incident line of flight (and thus the new direction via the general code), tiie new energy $E$ of the photon, and the local energy deposftion $E-E^{\prime}$ (the recoll k.e. of the electron).

Incoherent scattering is assumed to have the differential cross section $\sigma^{1}(z, \alpha, \mu) d \mu=I(z, v)$ $\times K(\alpha, \mu) d \mu$, where $I(Z, v)$ is an apprepriate scatterIng factor, moditying the klein-Wydina (R-N) cross sectfon

$k(\alpha, \nu) d \mu=\pi_{0}^{2}\left(\frac{\alpha^{-}}{\alpha}\right)^{2}\left\{\frac{\alpha^{-}}{\alpha}+\frac{\alpha}{\alpha}+\mu^{2}-1\right\} d \mu$.

As is customary, $a$ and $a^{-}$denote the incident and ecattered photon energles, respectively, In units of election rest enezgy me ${ }^{2}, \alpha^{-}=\alpha /[1+\alpha(1-j)]$, $\mu=\cos \theta$, and $r_{0}=e^{2} / \mathrm{mc}^{2}=2.81776 \times 10^{-13} \mathrm{~cm}$, the "classical electron radius."

qualitatively, the effect of $I(z, v) / Z$ is to decrease the $K-N$ cross section (per electron) wore extremely in the forward direction, for low $E$ and for high $z$ independently. For any $z, I(z, v)$ increases from $I(z, 0)=0$ to $I(z, \infty)=z$. The parameter $v=v(\alpha, \mu)$ is a given function of $\alpha$ and $\mu$ which, for a particular incldent energy $\alpha$, Increases from $v(\alpha, 1)=0$ at $u=1$ to a maximum value $\bar{v}=v(\alpha,-1)$ at $\mu=-1$. The essentlal features of $I(2, v)$ are fndicated in E1g. 1 .

The complete tabulations of Cromer and Mann 6,7 (and of Brown 8 for a few low $z$ ) are used for all $z>2, v<8$, and we set $I(z, v) \equiv z$ for $v>8$. These tables, for $v_{1}=0, \cdots, v_{21}=8$, are recorded without change on the LT, and those requited form

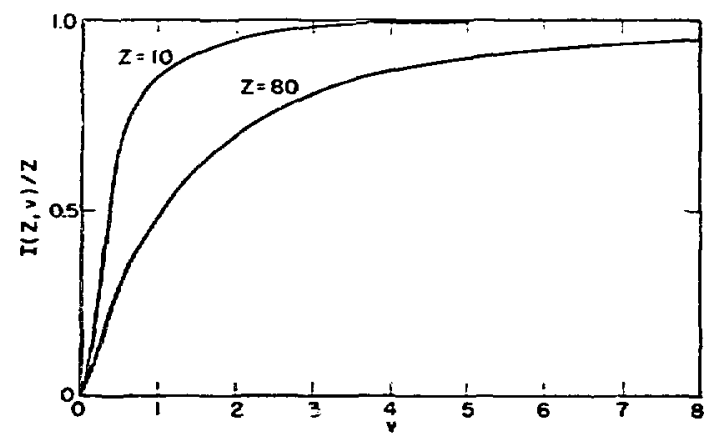

Plg. 1. Incoherent scattering factor.

part of problem storage. Linear interpolation is used as necessary. The parameter $v$ is here the Inverse length $v=\sin \frac{1}{2} \theta / \lambda(\AA)=\mathrm{Ka} \sqrt{1-u}$, $\mathrm{x}=10^{-8} \mathrm{ec} /(\sqrt{2} \mathrm{~h})=29.1445 \mathrm{~cm}^{-1}$, with maximal value $\vec{v}=\sqrt{2} \mathrm{kx}$ for given $a$.

For $z=1$, we use the exact formula $I(1, v)$. $1-\left(1+v^{2}\right)^{-4}$, with the dimensionless parameter $v=a \operatorname{mca} \sqrt{2(1-\mu) / 2 h}=k^{\prime} a \sqrt{1-\mu}, k^{-}-h c / \sqrt{2} e^{2}=$ $96.9014, \bar{v}=\sqrt{2} \mathrm{k}^{\prime} \mathrm{c}$. Here $\mathrm{a}=\mathrm{h}^{2} / \mathrm{me}^{2}$ 1s the first "Bohr radtus".

The method of sampling for $\mu=\cos \theta$, in both coherent and Incoherent scattering, Is based on the following:

Principle. Let $P(y)=c_{0} F(y) Q(y)$ on $(a, b)$, there $P(y)$ and $Q(y)$ are probab1lity densitles, $0<F(y)<1$, and $C_{0}>1$ is a constant. If a particle is tentatively assigned to $(y, y+d y)$ with probability $Q(y) d y$, but the assignment is ratifled only with probability $F(y)$, the process belng 1terated with probab1lity $1-\int_{a}^{b} g(y) Q(y) d y$, then the probability of the particle being definitely assigned to $(y, y+d y)$ ia $P(y) d y$. (The value of $C_{0}$ is 1rrelevant for the process). For, $\int_{a}^{b} F(y) Q(y) d y=c_{0}^{-1}<1$, and the probability in question is seen to be

$\sum_{k=0}^{\infty} F(y) Q(y) d y\left(1-c_{0}^{-1}\right)^{k}=C_{0} F(y) Q(y) d y$

$$
\text { - } P(y) d y \text {. }
$$

To apply this to incoherent scattering, we write $\sigma_{t}^{1}(z, \alpha)$ and $\sigma_{t}(\alpha)$ for the total incoherent and 
$\mathrm{K}-\mathrm{N}$ cross sections, and express the probability density for scattering into $(\mu, \mu+d \mu)$ in the form

$P(\mu) \equiv p^{1}(\mu) \equiv \sigma^{1}(z, \alpha, \mu) / \sigma_{t}^{1}(z, \alpha)=\frac{I(z, \bar{J}) \sigma_{\tau}(\alpha)}{\sigma_{t}^{1}(z, \alpha)}$

$$
\times \frac{I(Z, v)}{I(Z, v)} \times \frac{K(\alpha, \mu)}{\sigma_{t}(\alpha)}=C_{0} \times F(\mu) \times Q(\nu)
$$

We therefore assign $\mu$ tenatively with K-N probabil1ty $Q(\mu) \mathrm{d} \mu$, ratifying with probab1lity $F(\mu)=$ $I[z, v(\alpha, \mu)] /(z, \bar{v}) \leqslant 1$.

The tentative choice of $u$ is effected indirect$1 y$ as follows. Taking in place of $\mu$ the variable $x=1 /[1+\alpha(1-\mu)]$ on the interval $\xi \equiv 1 /(1+2 a)$ $<x<1$, and defining $p(x) \mathrm{d} x=Q(\mu) \mathrm{d} \mu$, one finds that $p(x)=g(x) / G(\xi)$, where $g(x)=x+x^{-1}+\mu^{2}-1$, $\mu \equiv 1+\alpha^{-1}-(\alpha x)^{-1}$, and in general,

$$
G(x) \equiv \int_{x}^{1} g(x) d x
$$

Thus we may deterwine $x$ by $r=G(x) / G(\xi)$, where $r$ is random on $(0,1)$, and so obtain $\mu$ with the required density $Q(\mu)$. A recently obtained appruxina$\operatorname{tion}^{2,3}$ for the 1nverse $x=H(y)$ of the function $y=G(x)$ allows rapid and accurate determination of $x=B[r G(\xi)]$.

Having obtained $\mu$, and $\alpha^{-}=c \alpha$, the fiaal energy of the photon is $E^{-}=m c^{2} \alpha^{\prime}$, and one deposits the energy $E-E^{\prime}$ locally. If $E^{-}<1 \mathrm{keV}, E^{-}$is tallied In a cut-off bin and one returns to the source subroutine of the general code. Otherwise the new direction is found from $\mu$, and one returns to the free path routine.

For the point detector routine of the general code, one requires, for a given $\mu$ (determined by the detector position), the probability of (incoherent) ocattering to the angular range $(\mu, \mu+d \mu)$, $p^{1}(\mu) d \mu=I(z, v) R(\alpha, \mu) d \mu / \sigma_{t}^{1}(z, \alpha)$. The values of $\pi x_{n}^{2}$ and of $\alpha^{\prime} / \alpha=1 /[1+\alpha(1-\mu)]$ are needed in $K(\alpha, \mu) ; I(2, v)$ is obtained by Linear Interpolation at the computed value of $v=v(\alpha, \mu)$; and $\sigma_{t}^{1}(z, \alpha)=$ $\sigma^{1}(z)$, at the inctdent energy $E$, is recoverable frow the free path routine.

Note on Momentum Transfer to the Electrons. The paremeter $v$ above $1 s$, except for constants, the ㅍomentum $q=a \sqrt{2(1-\psi i)}$ (u $u_{i}$ its of $\mathrm{mc}$ ). The latter seens to be used exclusively in theoretical computation of incoherent scattering factors. The following comparison of $q$ with the relativistic momentum transfer $q^{\prime}$ to the electron in Compton (elastic) scatterIng of photons on free electrons at rest may therefore be of interest. In this connection, see the SORS $^{10}$ and Union Carbide ${ }^{11}$ reports.

Since $\alpha^{-}=\alpha /[1+\alpha(1-\mu)]$, we have $k=\alpha-\alpha^{-}=$ $\alpha \alpha^{-}(1-\mu)$ for the k.e. of the recoll electron, and $E=k+1$ for its energy (units of $\mathrm{mc}^{2}$ ). Thus $E^{2}-1=k(k+2)=\left(\alpha-\alpha^{\prime}\right)^{2}+2 \alpha \alpha^{-}(1-\mu)=$ $\alpha^{2}+\alpha^{-2}-2 \alpha \alpha^{\mu} \mu$, and the electron momentum is

$$
q=\left(E^{2}-1\right)^{1 / 2}=\alpha\left[1+\left(\alpha^{-} / \alpha\right)^{2}-2\left(\alpha^{-} / \alpha\right) \mu\right]^{1 / 2},
$$

(units of mc)

as compared with $q=a \sqrt{2(1-\mu)}$. To say $q^{-} \cong q$ for $a^{\prime} \cong a$ is not very revealing, since $\mu$ is a function of $\alpha^{\prime}$ such that $\mu \rightarrow 1$ as $\alpha^{\prime}+\alpha$. Clearly, however, $q=0=q^{-}$exactly for $\mu=1$.

Fixing $\alpha>0$, and setting $x=1-\mu, 0<x<2$, one finds that $F(x) \equiv q^{2} / q^{-2}=(1+\alpha x)^{2} / D$, $D=1+\frac{1}{2}\left(\alpha^{2}+2 \omega\right) x>1$. Thus $F\left(0^{+}\right)=1$ and $F(2)=$ $(1+2 \alpha)^{2} /(1+c)^{2}>1$. Differentiation ylelds $\alpha^{-1}(1+\alpha x)^{-1} D^{2} F^{\prime}(x)=\left(1-\frac{\alpha}{2}\right)+\left(\frac{\alpha^{2}}{2}+\alpha\right) x$.

Case I. $(\alpha<2)$. Since $F^{-}(x)>0, q / q^{-}$increases from 1 to $(1+2 \alpha) /(1+\alpha)>1$, and the "relative error" $t(x)=q / q^{-}-1$ rises from 0 to 1 ts maximum value $\alpha /(1+a)$ at $\mu=-1$. For $\alpha=2$, this amounts to 677 , while even for $\alpha=0.2(E \sim 100 \mathrm{keV})$ 1t is already $17 \%$.

Case II. $(\alpha>2)$. Here, the maximum poattive ezror is $\varepsilon(2)=\alpha /(1+\alpha)+1$ as $\alpha \rightarrow \infty$. Since $F^{\prime}\left(x_{0}\right)=0$ at $x_{0}=(\alpha-2) /\left(\alpha^{2}+2 \alpha\right)$, and $F\left(x_{0}\right)=$ $8 \alpha /(\alpha+2)^{2}$, we conclude that the worst negative error (at $\mu_{0}=1-x_{0}$ ) 1s $\varepsilon\left(x_{0}\right)=(2 \sqrt{2 \alpha}) /(\alpha+3)$ $-1+-1$.

\section{COHERENT SCATTERING}

This process $(j=2)$ involves no energy loss, only the scattering angle $\theta$ being required before recurning the photon to the free path routine with Its new direction, obtained from the general code. The differential cross section is now $\sigma^{2}(z, \alpha, \mu) d \mu=c^{2}(z, v) T(\mu) d \mu$, where $c(z, v)$ la a form factor modifying the (energy Independent!) Thomson 
cross gection $T(\mu)=\pi r_{0}^{2}\left(1+\mu^{2}\right) d \mu$. (Superscripts on $\sigma$ 's denote process number $j$, not an exponent).

The general effect of $c^{2}(z, v) / z^{2}$ is to decrease the Thomson cross section, wore extremely for backward scattering, high E, and low $z$, belng opposite In these respects to the effect of $I(Z, v) / Z$ on $K(\alpha, \mu)$ In Section $C$ above. For a given $z, c(z, v)$ decreases from $c(z, 0)=z$ to $c(z, \infty)=0$. The parameter 18 here the $v=\operatorname{Ra} \sqrt{1-\mu}$ of that section, with maximum $\bar{v}=\sqrt{2} \mathrm{ka}$ for given $a$. The qualitative features of $C(z, v)$ are shown in $F i z$. 2 .

The requited cables of $c(z, v)$, for $z>1, v \leqslant 6$, were compiled frow various sources, $(12,13,14)$ with values lloted for $v_{1}=0, \cdots, v_{55}=6$. (For deca11s, see Storm and Israel $\left.{ }^{5}\right)$. We define $c(z, v) \equiv 0$ for $v>6$.

To Improve efficlency in applying the Principle of Se:. C, we follow a device of the sors report, 10 and reverse the roles of the coherent cross section components. Denoting by $\mathrm{p}^{2}(\mu)=\sigma^{2}(z, \alpha, \mu) / \sigma_{t}^{2}(z, \alpha)$ the probability density for $\mu$, we have

$$
P\left(v^{2}\right) d v^{2}-p^{2}(\mu)\left|\frac{d \mu}{d v^{2}}\right| d v^{2},
$$

where $\mu$ is replaced by the variable $v^{2}=(\mathrm{Ka})^{2}(1-\mu)$. $0<v^{2}<\bar{v}^{2}$. siace $\mu=1-v^{2} /(R a)^{2}, d \mu / d v^{2}=$ $-1 /(R \alpha)^{2}$, and we may write

$$
\begin{gathered}
P\left(v^{2}\right) d v^{2}=\frac{2 \pi r_{0}^{2} z^{2} A\left(z, v^{2}\right)}{(R \alpha)^{2} \sigma_{t}^{2}(z, \alpha)} \cdot \frac{1+\mu^{2}}{2} \cdot Q\left(v^{2}\right) d v^{2} \\
\quad \equiv c_{0} F\left(v^{2}\right) \cdot Q\left(v^{2}\right) d v^{2},
\end{gathered}
$$

where

$$
Q\left(v^{2}\right)=c^{2}\left(z, v^{2}, z^{-2} / A\left(z, v^{2}\right),\right.
$$

and $A\left(z, v^{2}\right)=\int_{0}^{v^{2}} c^{2}\left(z, v^{2}\right) z^{-2} d v^{2}$

for arbitrary $v^{2}$.

A random number $r$ on $(0,1)$ may therefore be used to tentatively assign $v^{2}$ with density $Q\left(v^{2}\right)$, by the relation $r=A\left(Z, v^{2}\right) / A\left(Z, \vec{v}^{2}\right), v^{2}$ being

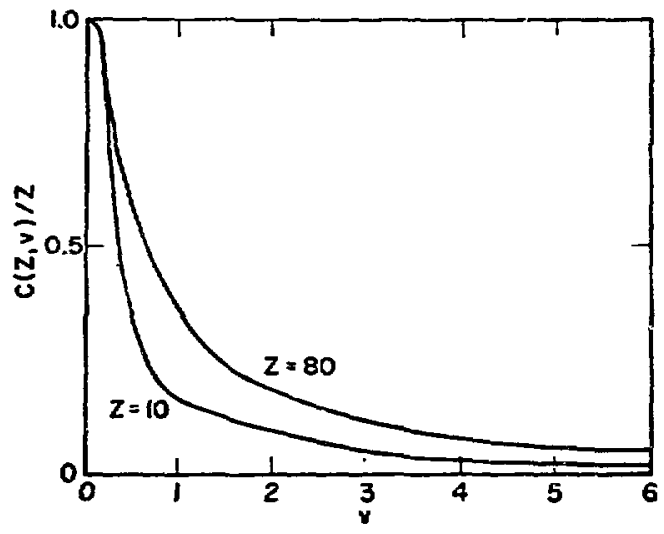

Fig. 2. Coherent scattering factor.

ratifled with probability $F\left(v^{2}\right)=\frac{1}{2}\left(1+\mu^{2}\right)<1$, where $\mu$ is the above function of $v^{2}$.

The required values of $A\left(2, \bar{v}^{2}\right)$ and of $v^{2}$ are obtained by linear interpolation, using rahles of $A\left(2, v_{1}^{2}\right), v_{1}^{2}=0, \cdots, v_{55}^{2}=36$, obcalned by numerical lategration of the data c1ted, and stored on the $I T$.

For the point detector program, one uust evalvate the density $p^{2}(\mu)=\pi r_{0}^{2}\left(1+\mu^{2}\right) c^{2}(2, v) j \sigma_{t}^{2}(2, \alpha)$ for given $\mu$. Although $\sigma_{t}^{2}(z, \alpha)=\sigma^{2}(2)$ is recoverable frow the $\lambda$ routine, the value of $c^{2}(z, v)$ at $v=R n \sqrt{1-\mu}$ wust be interpolated in the original $c^{2}\left(2, v_{1}\right)$ tables, separately stored on the LT for th1s purpose.

\section{E. PHOTOELECTRIC EFFECT}

A collision of this type $(\mathrm{j}-3)$ Involves the disappearance of the incideat photon of energy $\mathrm{E}$, the ejection frow some (positively written) energy level $e<E$ of an orbital electron with k.e. E-e, and the transition of a second electron frow a level $e^{-}<$e to the e-level vacancy. There are two possib1lities.

(1) A (fluorescence) photon of energy $E^{-}=\mathrm{e}-\mathrm{e}^{\prime}$ way be exitted. In such a case, the photon energy difference $E-E^{-}-(E-e)+e^{-}$consists of the k.e. of the first ejected electron, plus a residual excitation energy $e^{-}$which is ultimately dissipated by further processes, with additional fluorescence of still lower energy. Th1s we lgnore, depositing all of $E-E^{\prime}$ locally, and returning to the $\lambda$ rout ine with the (1sotropically emitted) Eluorescence photon of energy $E^{\prime}$, provlded of course that $E^{\prime}>1$ kel. 
Otherwse the event 15 "terolnal", ty whlch is beant that the Incident photon's history terelnates, Its energ: E belng locally deposited, and the cods returns to the source routhe of MCP.

(2) The electron cransition $e^{\circ}$ - e any not be accospanted by $\varepsilon^{-}$- e - Eluorescence, but by the ejection of an "Auger electron". resuletrs frae "internal converslos". In this event, the entize Incident energy $E$ is callied as energy depesteion, and the collstion is terainal.

The energy levels e are called "edge energles" because, regarded as a function of intreanins $E$, the photoelectrle cross section $\sigma(\varepsilon)$, elsewheze decreasing coneinuoucly, shows a shapp disfortinutey (elige) at each $E$ - e, Jumping frow 1ts luyer. 11atcIng value $\sigma\left(e^{-}\right)$to $2 t s$ value $\sigma(e)>\sigma\left(e^{-}\right)$as the photon energy $\dot{E}$ becoses sufficlent co activate the c-level.

A photoeiectric event 13 regarded a cerninal for elenents $Z<12$, the posstble fluosesence energy being balow $1 \mathrm{kaV}$.

For clements $2>12$, Quorescent exission above $1 \mathrm{keV}$ is posstbla and allowed for to the extent Indicated below, using basic dass from a tinkon Carbide report ${ }^{21}$ whteh provides. Ior each $z$, a Eable of the forw

$\begin{array}{llll}e_{2} & a_{1} & y_{1} & F_{1} \\ \cdot & \cdot & \cdot & \cdot \\ i & \cdot & \cdot & \cdot \\ c_{f-1} & \sigma_{f-1} & y_{E-1} & F_{f-1} \\ f_{E}^{\prime \prime} & a_{f} & q_{f}=0 & F_{f}=0\end{array}$

where the energles are in decrasulns order. These tables have been prepared in a racher involved way. referrat to in a later note. For our landiece objective, which is almply the deteraination of the energy of the fluoremence photons entered, if uny, the following renarka wiflce.

Define in teras of the $e_{1}, c_{1}$ above the number 6

$$
\begin{aligned}
& \hat{v}_{1}-a_{1} \mathrm{e}_{1}^{3}-a_{2} \mathrm{e}_{2}^{3}
\end{aligned}
$$

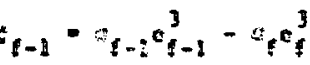

$$
\begin{aligned}
& t^{t} \cdot \theta_{t} e^{3}
\end{aligned}
$$

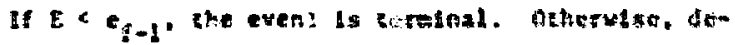

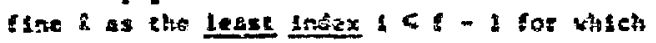

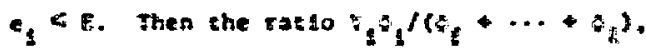
$1-$ - $-1, \cdots$, e represents the probasidey of tho event resuletng in a florescence phoson ot oforay $F_{1}$.

The data in chis cors is very itcosteateat for

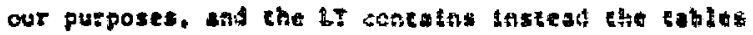

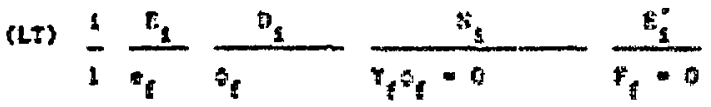

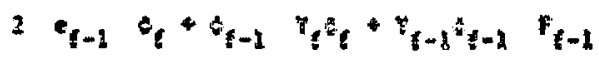

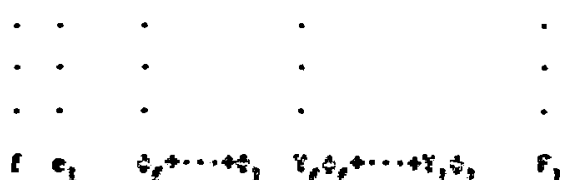

accordingly, our wertad in ske artas $f * 3, z \geqslant 12$,

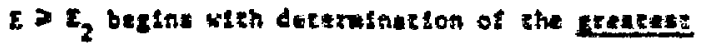
index $k$ fer wich $E_{z}<E$, and foraceion of the prod"

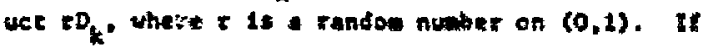
$r D_{k}>H_{k}$, the crant is cerminal. Oehorulies, the

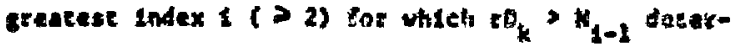
ofnes the enersy $E_{i}$ of the fuoresent phocon ensiced.

Note on the tublet. For steplictey, ve describe fizat a cable of the fort (te) bove, of the followIns nature: (2) $a_{1}$ ls the energy level of she $\mathrm{K}-$ shatl and any further $e_{1}, 1<t-1$, aze average earales for the compond the she $L, H, N, \cdots$ in that order, ef-1 - teftis that of the ousermose thell allawed for; $(2) c_{2}-\sigma\left(v_{1}\right)$ is the pesk kredge $O(E)$ and for further 1 < $E-1, O_{1}$ is an average of the pack $\sigma(E)$ values for the thell in question, the clnal $o_{f}$ beint the lowe liate of $o(E)$ for shell $f-1$; (3) $X_{1}$ 1e the probability of enlaston of a fuorescent photen if the 1 -shell is activated; 


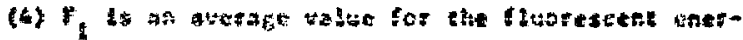

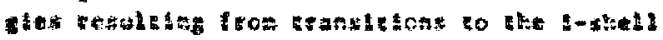
trestey tros onter shells.

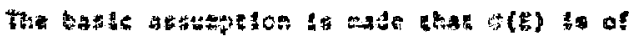

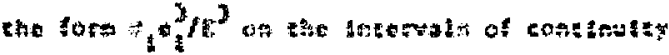

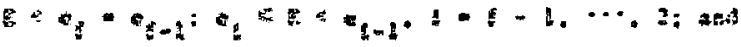

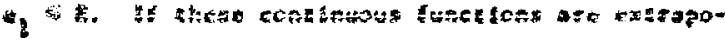

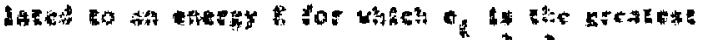

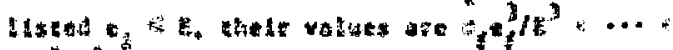

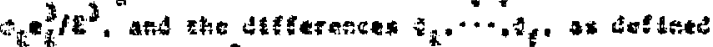

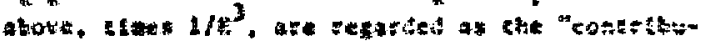

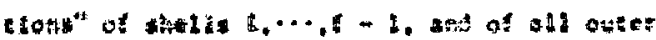

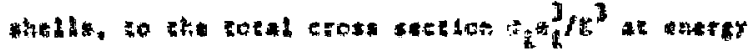

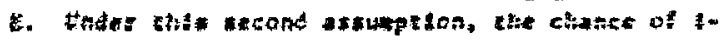

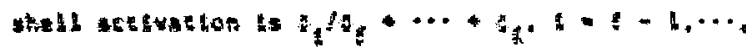

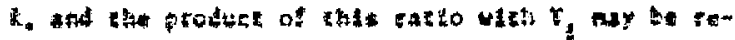

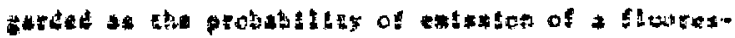

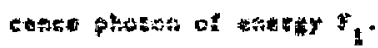

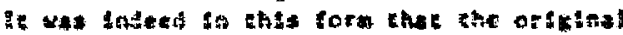

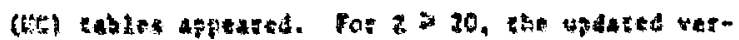

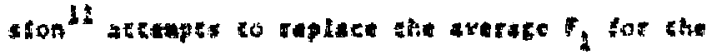

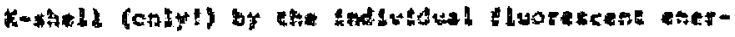

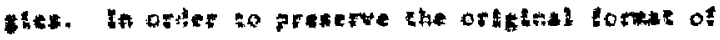

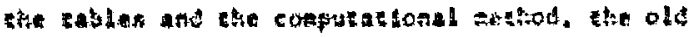

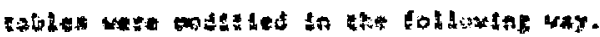

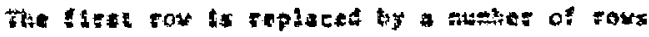
\& 2. 2. … h, cat for each t-shald fluorexcence

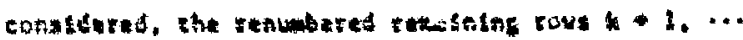

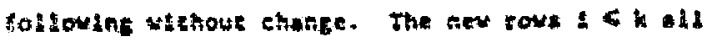

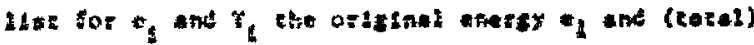
ylete $r_{1}$ for the k-shell, and for $r_{1}$ the thoreacent

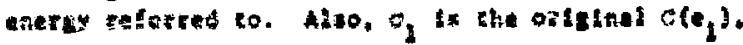
tar the k-penk.

Stece, toz an etwerty E o., che ceral proba-

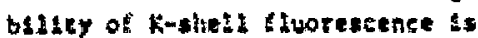

$$
r-r_{1} f \theta_{1} *_{1}^{3}-c_{k+1} *_{k+2}^{3} r \varepsilon_{1} *_{2}^{3}
$$

It carat of the nec auberting. It to ragulzed to in-

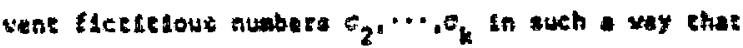

$$
\begin{gathered}
\left(0_{1} z_{1}^{3}-\sigma_{1+1} e_{1+1}^{3}\right) /\left(o_{1} e_{1}^{3}-o_{k+1} e_{k+1}^{3}\right)-p_{1} \cdot \\
1-1,2, \cdots, k-1
\end{gathered}
$$

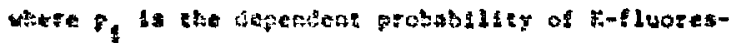

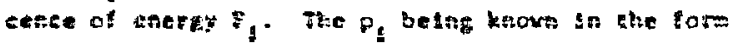

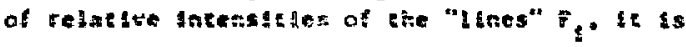
-aty so cropute the desiget $\tau_{2}, \cdots$, iz lrom these cquaters.

The posatilaty of F, eplation is shen

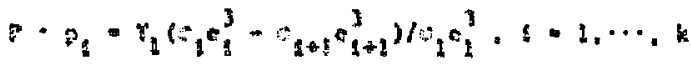

for $t-c_{j} \cdot \ldots-e_{k}$ ard the sethod is wehanged

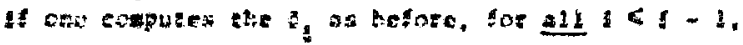

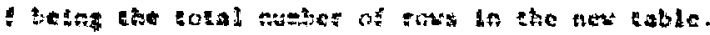
for trattin of the the struture constgoted, one siould conkule the tir. report.

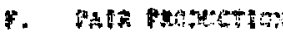

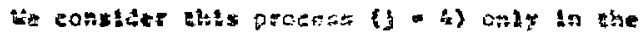

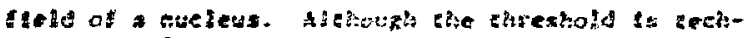

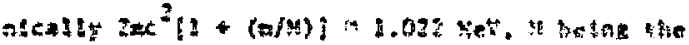

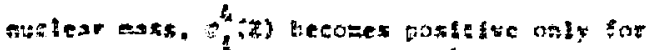

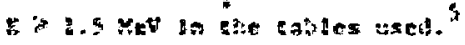

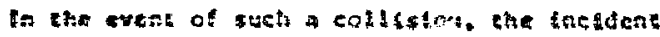

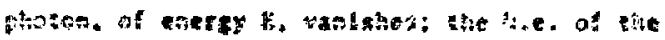

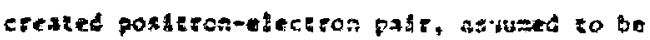
4. - 2es". As depostice: locally: the posterch is eon-

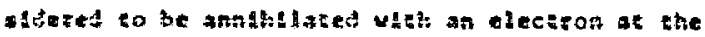
polth of colliston: and a single photen of wefthe

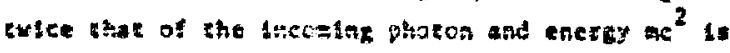

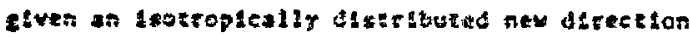

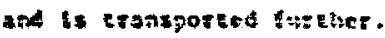

\section{Estart Maste}

If att ocher ffects (breastahisnt. ezc.) are trnoted, nothing provents exteftston of the code to

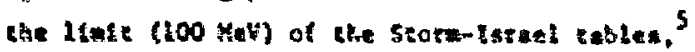
the approxisution for the inyerse to the kleftn-

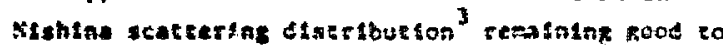
thot energy.

\section{H. veluntes of the cos:}

Apret tow the coilstan pourtne wheh has been described in sose decall above, tho codes MCP and we have fer differences. As wentloned in the ln-

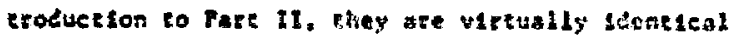
to use and have almoge tenteal ontpues. Roth of these colles are qute stmilat th problutere up and output to the sorce carto neutron code Mct. is to 
avold duplication, let us refer the reader to Secclons D, E, F, Apend $2 x A$ and Append $1 x$ of Pare $I$. and beloy ve $115 \mathrm{t}$ che exceptions to this discussic? which epply to the use of MCP.

Exceptions. (1) the second tten on the run eard for MP is the energy cut-off ECF (not welght eut-ofi kC) and chis is the same for all cells. There ate no velthe cut-of is WC and kx used In HCP since capcure to nat trented by velghte (1.e., earlaetint the capture per collssion by reducing the particle volthe). Thus the rus card will have only 7 encties with entry 2 modified as above.

(2) The $Y 7$ card is not used in MCP slace ve do not have enersy cur-otfs at funceion of cell.

\section{NGEAEEES}

1. E. D. Cachueld, J. R. Neergand, H. M. Taylor, and C. $D$. Turnez, "HEN: A Meutron Honte Carlo Code, "Los Alases Selentif le Laboratory report LA-4751 (January 1972).

2. C. I. Evatete and E. D. Casme11, "Approximeton tot the Inverse of the Kleln-N1shina Probabilicy Distribution." Los Alawos Sctentiflc Laboratory repore LA-446s (June 1970).

3. C. J. Everete, E. D. Cuchuel1, and C. D. Turner, "A Mew Hathod of sappling the Klein-Nishina Trobeb1tity OAseribution for All Ineldene Enerctes Abore i keV," Los Alawos Setentific Laboratory repore La-4653 (Aprt1 1971).

4. C. J. Evereze, "A Relazivicy Hozebook for Monze Cat 20 Pracelee," Los Alemos Sctenelf1e Luboracory report LA-3839, p. 120 (1968).
5. E. Storo and H. I. Israel, "Phocon Cross Sections from 1 key to 100 Mey for Elements $Z=1$ to $z=100$," suclear Data Tádes 7, 565-681 (1:70).

6. D. T. Cromer and J. B. Mann, "Compton Scatterting Sacrors for Spherically Symetric Free Atoms," Jour. Chem. Phys. 47, 1892-1893 (1967).

7. D. T. Crower, "Compton Scatcering Factors for Aspherleal Free Atoss," Jour. Chen. Phys. 50. 4857-4859 (1969).

B. R. T. Broun, EGGG. Ine., report L-958 (1969) and unpubls shed data.

9. G. H. Grodsce1n, "K-ray Attenuation Coefficients froo $10 \mathrm{keV}$ to $100 \mathrm{MeV} . " \mathrm{H} . B . S$. C1reular 583 (1957).

10. J. H. Kinliager, E. F. Plechaty, and J. R. TezraU, "SORS Monte Carlo Photon-Transport Code," Lahrente Radiation Laboratory report UCRL-S0358.

11. C. R. Marotea, "Updaced Master L1brary Tape for PHOTRay," Union Carblde Corp. zeport AFWL-TR-67-11 (1967).

12. P. A. Doyle and P. S. Turner, "Relativ1st1c Hartree-Fock K-ray Elect5on Scatcering Fuctors." Acta Cryst. 24. 390-397 (1968).

13. D. T. Cromer and J. T. Waber (to appear in supplewent to Vol. III of International Tables for $x$-ray Cryatal Lography).

14. H. P. Hanson, F. Hernan, J. D. Lea, and S. Sk11lean, "hFs Aconde Scactering Factors," Acta Cryat. 27, 2060-1044 (1964). 
In order to lllustrace the steps iti setcing up a cypical probles for the codes MCG and XCP, as well as to portray the outpur features of ehcse codes, we shall set up and run the sace problex wh these codes. We will use the geometry shown in Flgs. C-1 and $C-2$ in Appendix $C$ of $L A-475\}$ with the exception that Surface 18, the left bounding plase, is not taken to be a reflesting plane. (The reflecting plane upsecs the escimation of the flux at the point detector in the present codes, Including res.)

thile the geosetzy is quite sidilar to that in LA-4751, the source is diffezent. Also the tally bins are apecifiled anew, to a large extent a reflection of the diflerences betueen processing neutrons and photons. In the following we shall specify completely the input to the problew, with the exception of the geometry, independently of the sample problem for MCN given in LA-475I.

A. Source. The source is essured to be uniformly diatributed in volume chroughout cell 1 and leotropic in direction. Because we are taldying aninly along the positive $y$ direction, we blased the directional distribution, sending threc-fourths of the particles 1sotropically with positive $v$ (v is the $y$-direction cosine) and one-fourth of the pareicles 1sotropically with negative $v$, correcting the wedghts of the source particles so that one-half of the expected weight has positive $v$ and one-half has negative $v$.

In addition, the energy distrijution of the source has been blesed in order to exphasize the source particles of higher energies. The inforwation Is displayed in Table $I$, with the saurce enerby bins (Wo card), tite actual fractions of the particles in each source broup (Vo card), and the fictitious (blesed) fractions in each source group (U0 card). The procedure follows exactly the description of the Source Cards on PP. 10-11 of 1A-4751.

If the problem has a twe cut-off of 100 shakes (escentialiy infinite time cut-off for this probles), we ask for the following information.
TABLE I

SOLRCE

\begin{tabular}{|c|c|c|c|}
\hline Group & $\begin{array}{c}\begin{array}{c}\text { Ener } \\
\text { in KeV (Ho) }\end{array} \\
\end{array}$ & $\begin{array}{c}\text { Frsections } \\
\text { In Group (UO) }\end{array}$ & $\begin{array}{l}\text { Traek Fractions } \\
\text { In Croup (UO) }\end{array}$ \\
\hline 1 & 0.001 & 0.0 & 0.0 \\
\hline 2 & 0.01 & 0.1 & 0.02 \\
\hline 3 & 0.1 & 0.2 & 0.08 \\
\hline 4 & 0.5 & 0.3 & 0.2 \\
\hline 5 & 1.0 & 0.3 & 0.3 \\
\hline 6 & 5.0 & 0.05 & 0.2 \\
\hline 7 & 10.0 & 0.03 & 0.15 \\
\hline 8 & 14.0 & 0.02 & 0.05 \\
\hline
\end{tabular}

B. Currents. Telly currents across surfaces 2, 10. 21 , and 14 for

energles: $0-0.005,0.005-0.01,0.01-1.0$, $1.0-5.0,5.0-i 6.0$ (HeV)

tImes: 0-100 (shakes)

angles: $\quad 1.0-0.8,0.8-0.6,0.6-0.4$. $0.4-0.2,0.2-0$ (values are for the cosine of the angle with the norant to the surface).

C. Flux Across Surfaced. Tally the flux integrated over surface 17 for

$$
\begin{array}{ll}
\text { energles: } & 0-0.005,0.005-0.01,0.01-1.0, \\
& 1.0-5.0,5.0-14.0 \text { (MeV) } \\
\text { tines: } & 0-0.01,0.01-0.1,0.1-1.0 . \\
& 1.0-10.0 \text { (shaikes) }
\end{array}
$$

D. Flux in a Cell. Tally the average $f$ lux in Cell 3 for

$$
\begin{aligned}
& \text { energies: } \begin{array}{r}
0-0.1,0.1-0.5,0.5-1.0,1.0-5.0, \\
5.0-14.0(\mathrm{keV})
\end{array} \\
& \text { telwes: } \begin{aligned}
0-0.01,0.01-0.1,0.1-1.0, \\
1.0-10.0 \text { (shakes) }
\end{aligned} \\
& \text { cell voluwes: } 245.52\left(\mathrm{~cm}^{3}\right)
\end{aligned}
$$


E. Five at a Polat. Tally the flix at che potac $(0,10,25)$ for

eneretes: 0-0.005, 0.005-0.01, 0.01-1.0,

1.0-5.0, 5.0-16.0 (Mev)

cines: $\quad 0-0.01,0.01-0.1,0.1-1.0$,

1.0-10.0 (shakes)

cells contedbucins to polnt detector: all call:

TALL II

cte Quniritrs

\section{Gell}

1

2

3

4

5

6

7

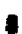

9

30

21

12

13

14

25

16

17

18

19

20

21

22

23

24

25

26

27

28

29

30

31

32

\section{Ievortence}

1.0

1.0

2.0

2.0

2.0

4.0

4.0

c.

8.0

16.0

a. 0

32.0

16.0

32.0

1.0

1.0

1.0

1. 0

1.0

1.0

1.0

4.0

4.0

8. 0

c. 0

1.0

1.0

2.0

2.0

4.0

1.0

0.0
Ientr Cue 0 CE

0.001 (nev)

0.002

0.002

0.001

0.001

2.001

0.001

0.001

0.001

0.061

0.001

0.001

0.001

0.001

0.001

0.001

0.001

0.001

0.001

0.001

0.001

0.001

0.001

0.001

0.001

0.001

0.001

0.001

0.001

0.001

0.001

0.001
TALEE III

Matzial densities

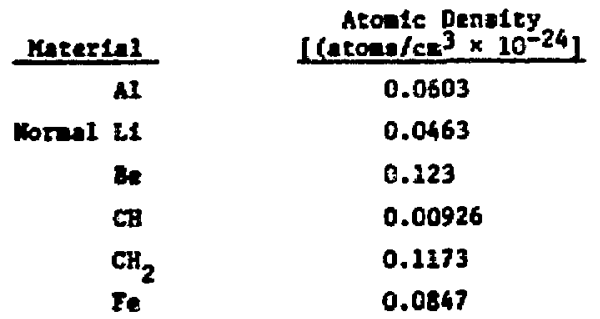

cles cut-off -100 shates

ux $=10^{-3}$

in $=10^{-4}$ 
TABLE IV

SAMPLE RUN - HCG

Juchoutine sounet

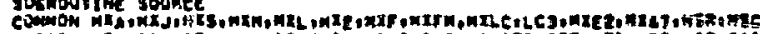

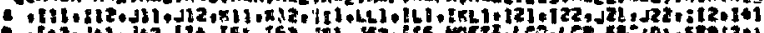

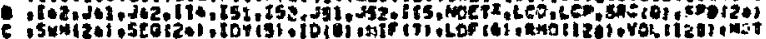

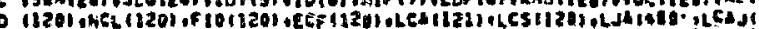

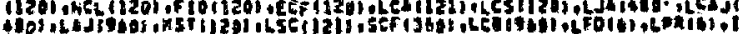

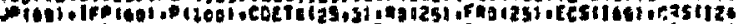

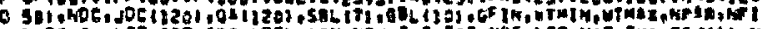

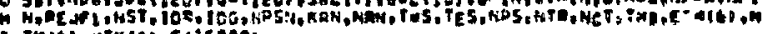

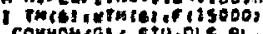

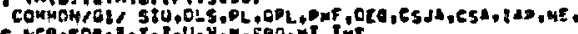

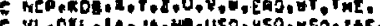

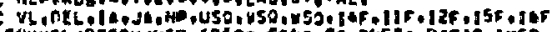

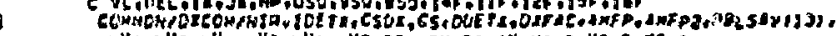

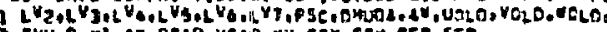

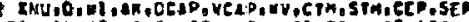

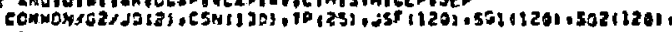

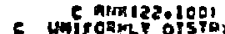

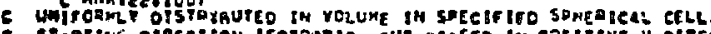

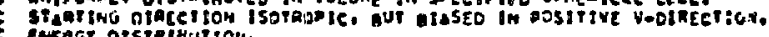

weat ofstaination.

57 capo afougen gh sIanLEN ctea.

SRC III ICECL MUMAE.

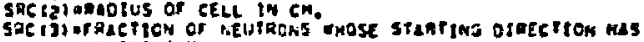
oositive $Y$.

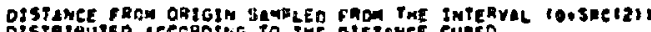

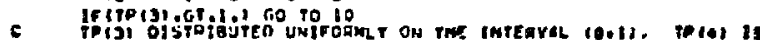

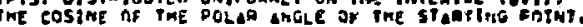

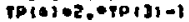

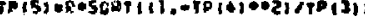

teg. 90 is

TotPIIITPISI

If Telsimtolis

c SET $y$ enstive sqeisi of tre tiwe.

Yenasivi

$\exists=0.5>50[13$

IAUsacti

Jani 1

TMEis

A-FRM(KAN)

Op $30102+0^{\circ}$

Contimis

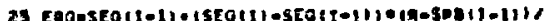

ispaiti-spait-11

vievtesumili

ge JuAn

l-5Rec3) of TME TINE.

30 vompsivi

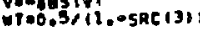

60 to 15 


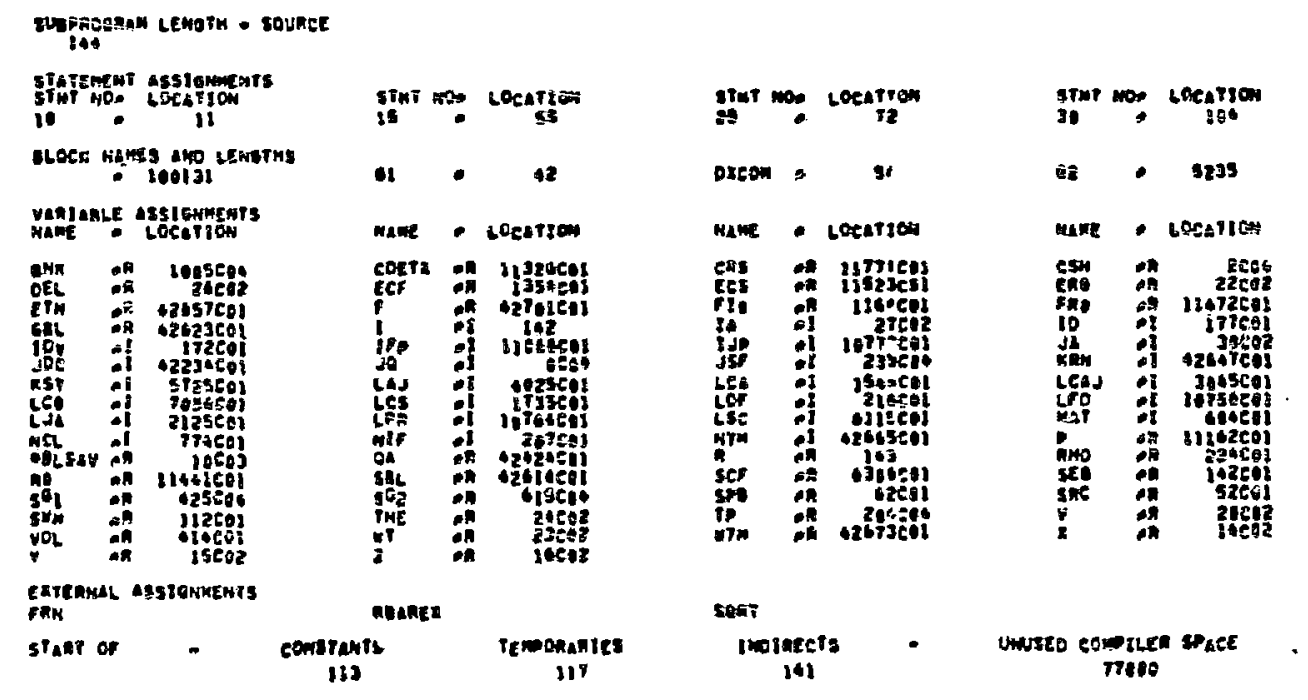

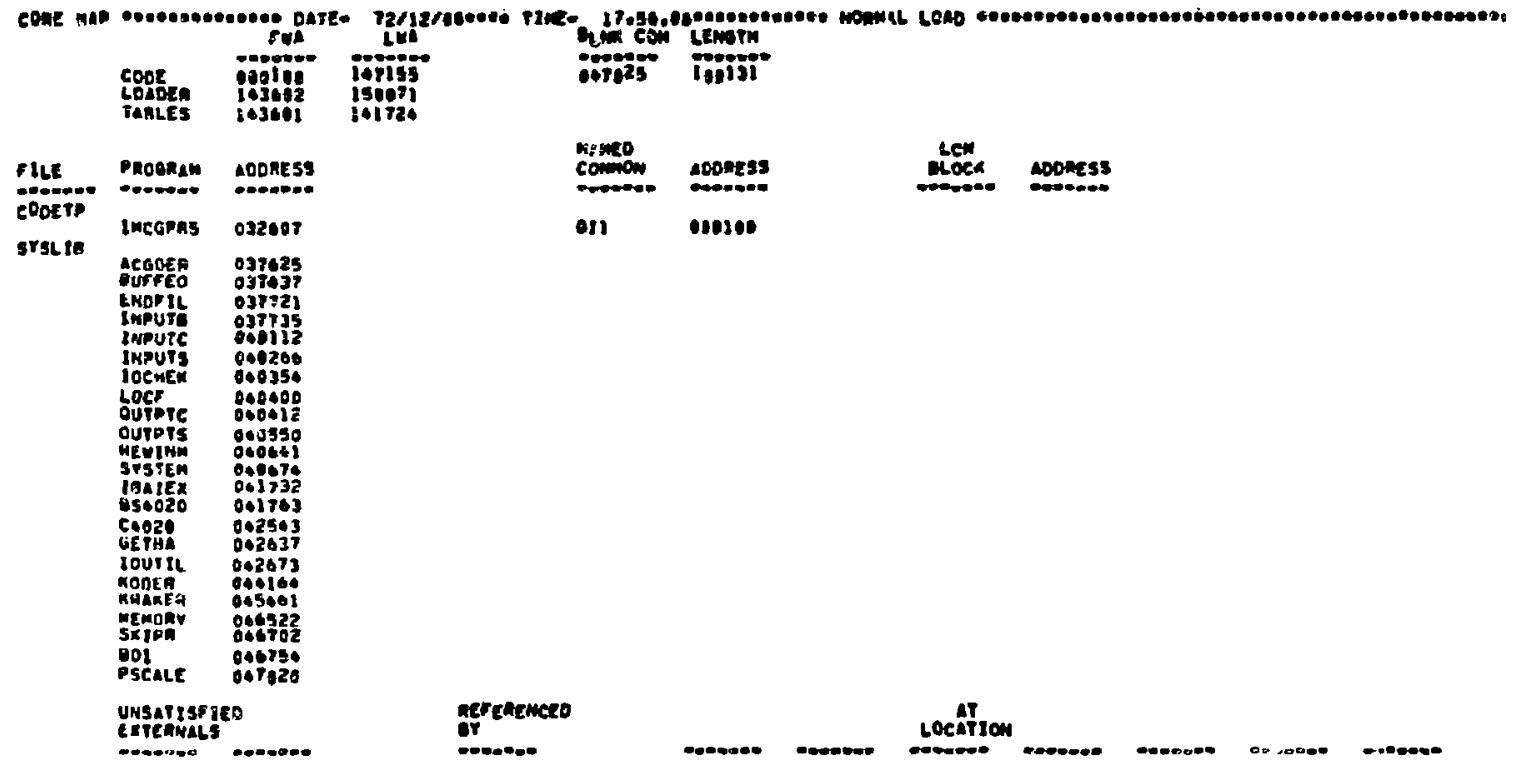




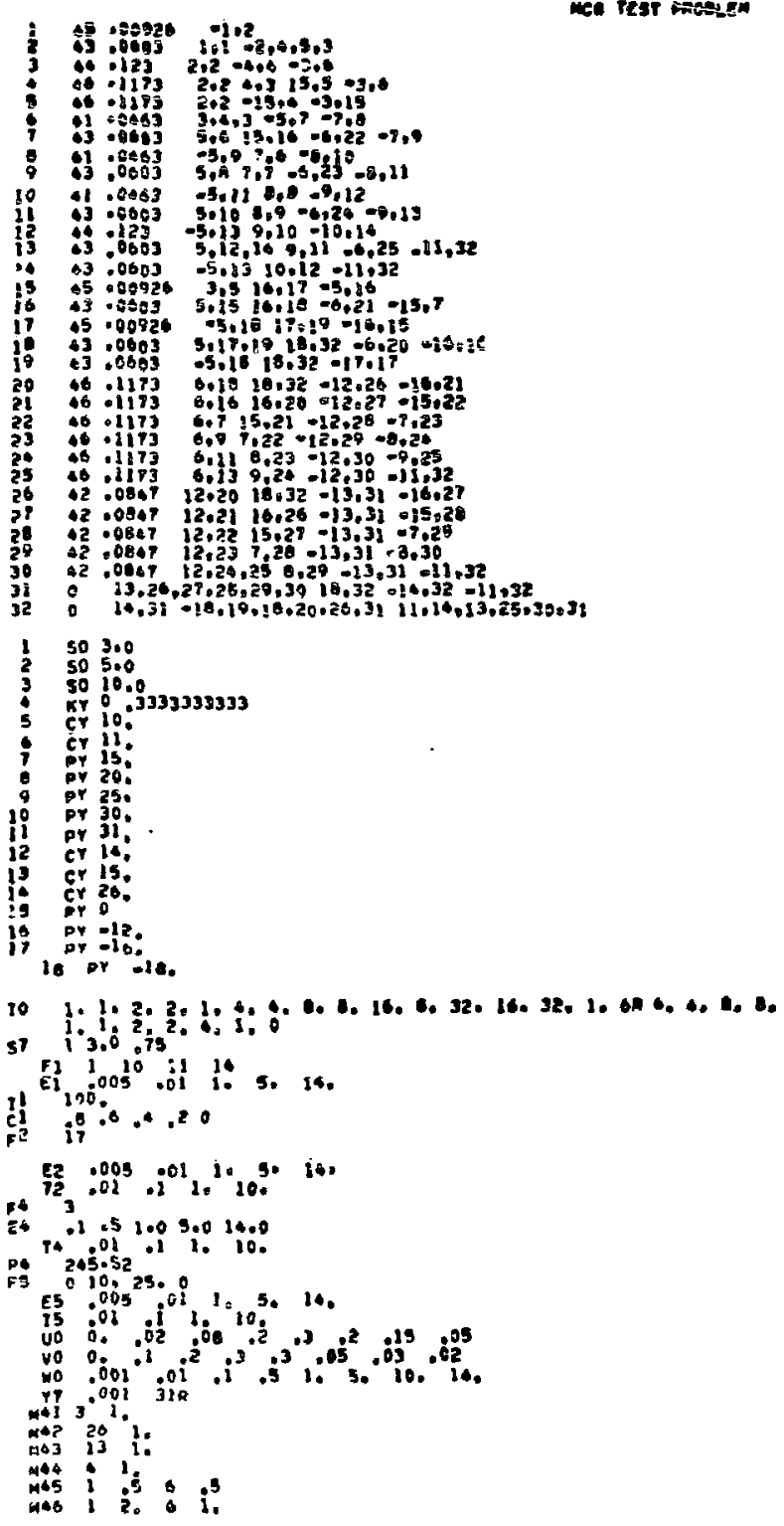




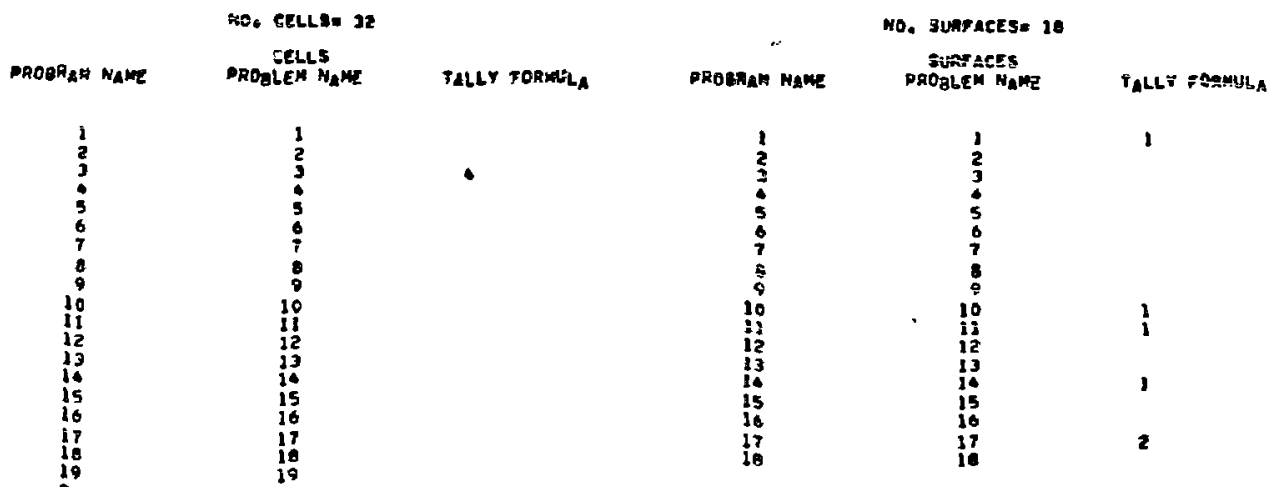

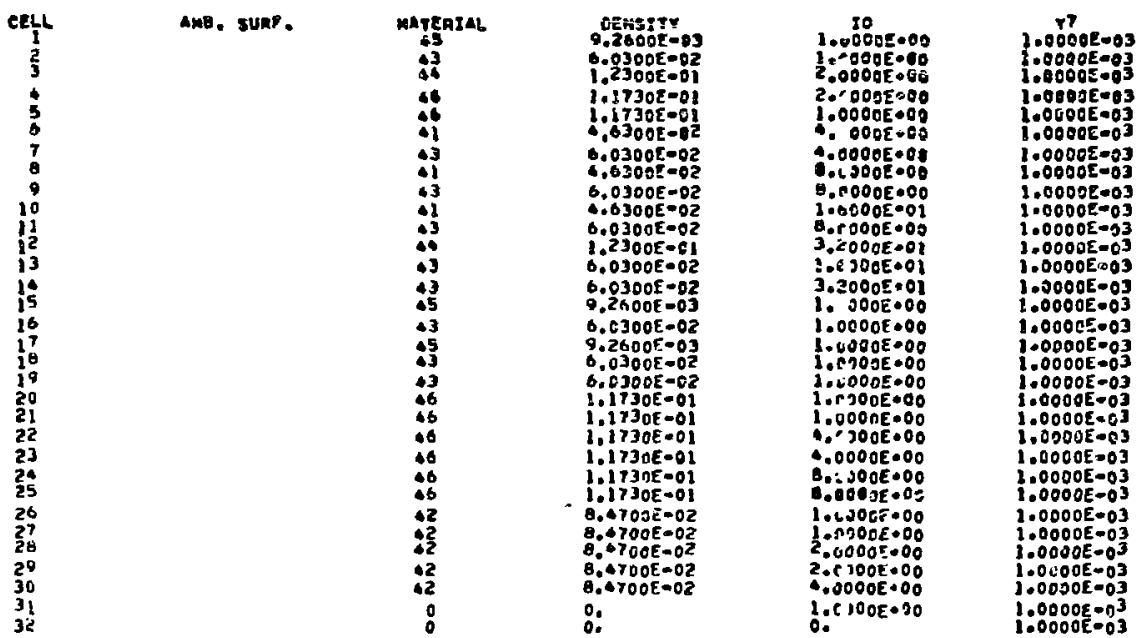

roRmULA 1 - PNOTONS CAOSSIHO SURFACT

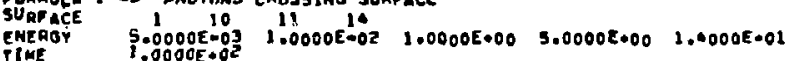

COSINE $\quad 8.0000 E-01$ b.0000E-01 $4.0000 E-01$ 2.0000E-01 0.

FORMUL. 2 -O FLUX INTEGRATEO OVEA SURFACE

SUAFACE
ENERGY
IIME

COAMULA - O PATH LENGTH VOLUME

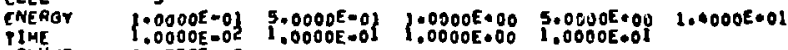

VOLUUME $2 . \$ 552 E \bullet 02$

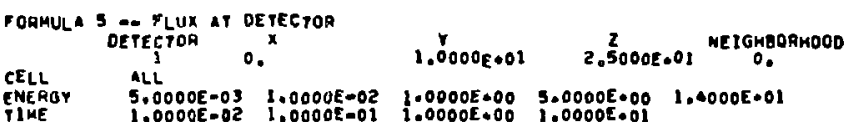




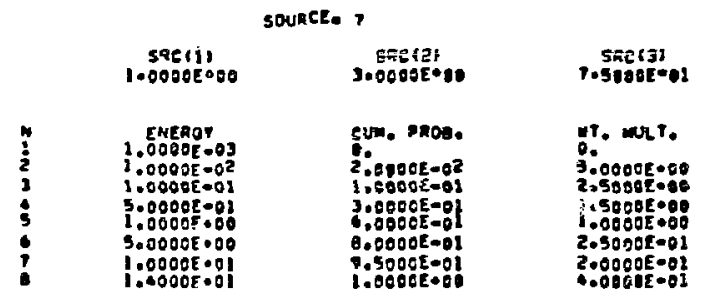

matenial data

\begin{tabular}{|c|c|c|}
\hline meT: wo. & elem; mo. & $\begin{array}{l}\text { minetron } \\
i, \text { ingerto }\end{array}$ \\
\hline$m_{\rightarrow 2} * 5$. & $\operatorname{cscm}_{i_{6}}$ mo, & $\begin{array}{l}\text { Faction } \\
2.00000\end{array}$ \\
\hline${ }_{\text {WT }}$ & $\underset{13}{\text { ELEM, wO. }}$ & $\begin{array}{c}\text { Praction } \\
2,100000\end{array}$ \\
\hline MaT. NO. & ELEN; ND. & $\begin{array}{l}\text { Tractiom } \\
1.00000\end{array}$ \\
\hline Hat, No. & ELEN; & $\begin{array}{l}\text { FRACTICM } \\
59000 \\
.50000\end{array}$ \\
\hline$m$ mo. & ELE: & $\begin{array}{l}\text { IaAction } \\
.68567 \\
.33533\end{array}$ \\
\hline
\end{tabular}

IMtTIATZON COMALETEO 


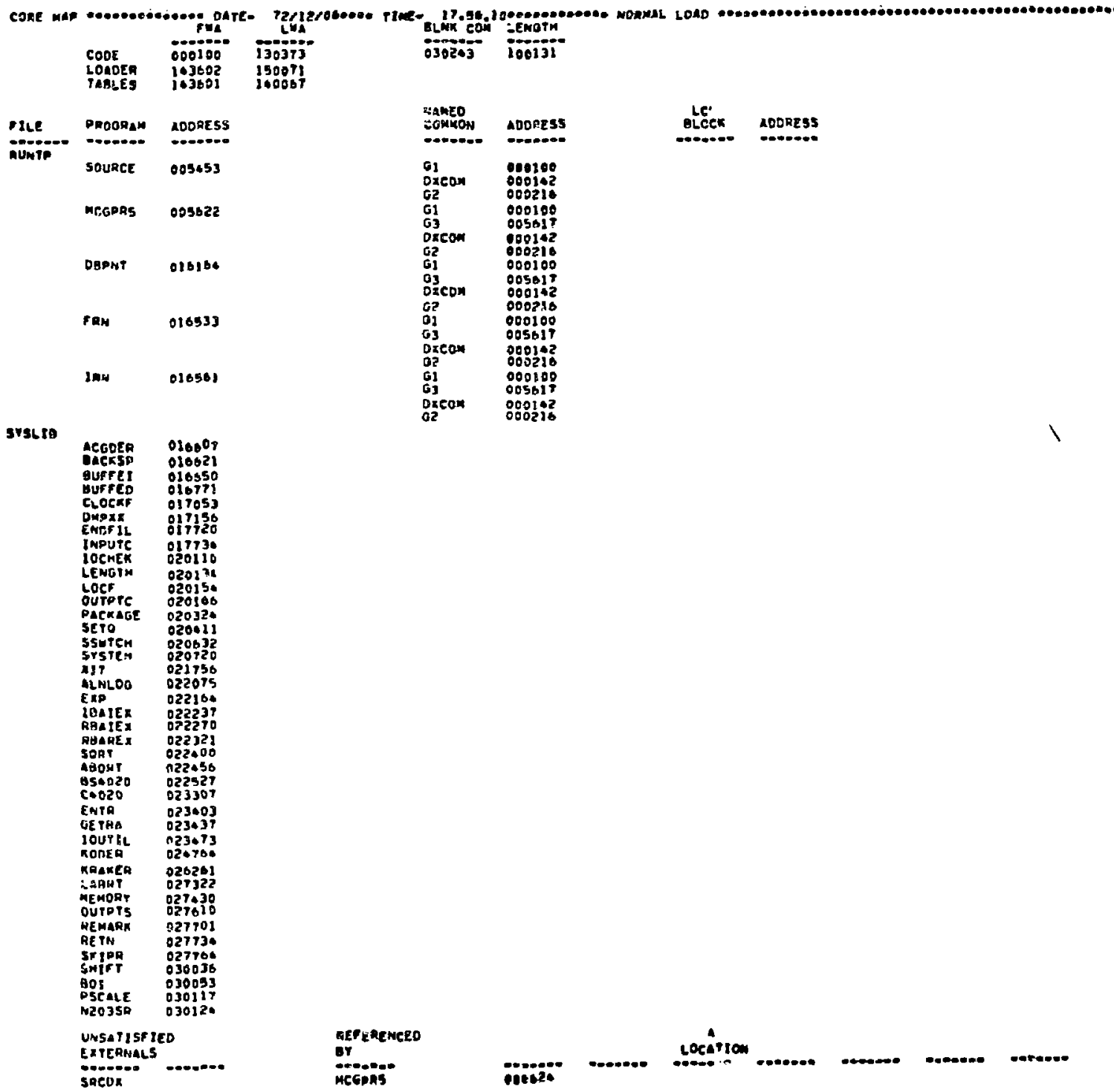




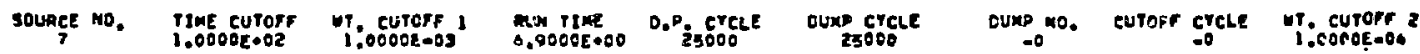

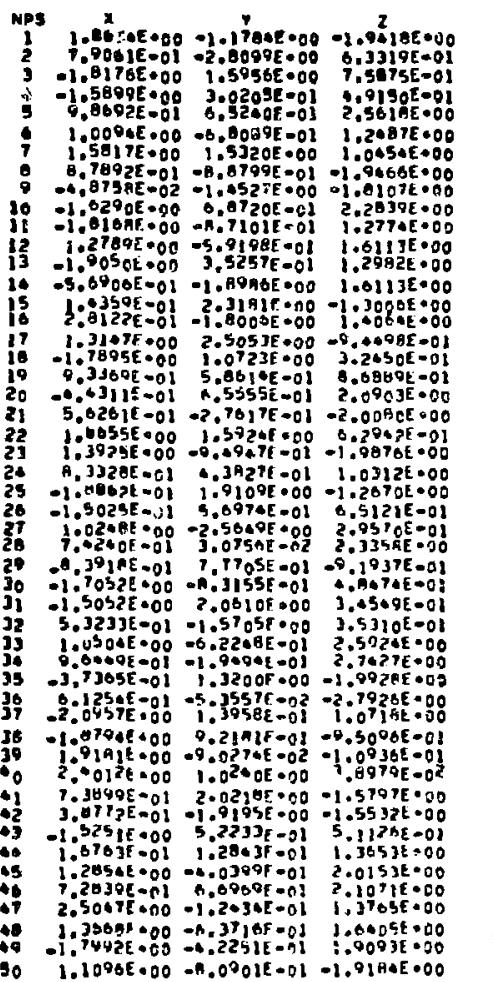

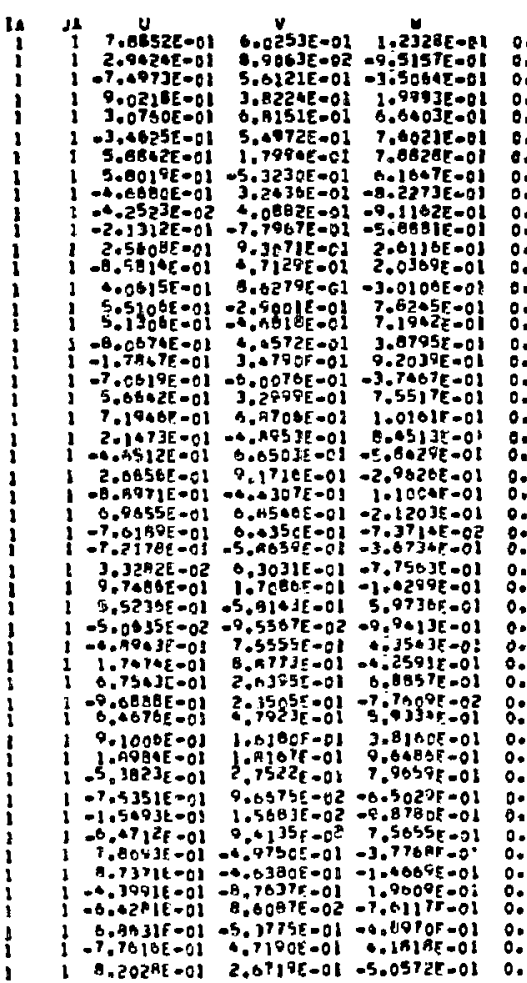

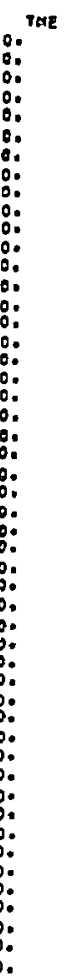

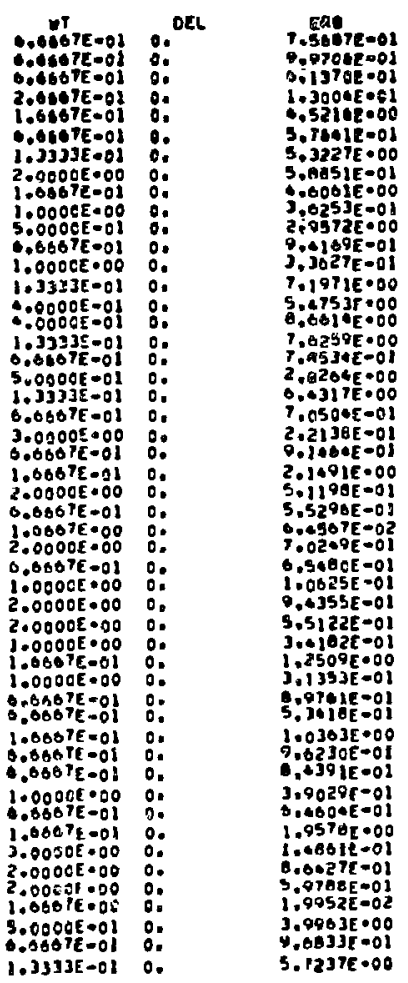

MEO TEST PROBLEM

TIME. 0.071 MINUTES

\begin{tabular}{|c|c|c|c|c|c|c|c|c|}
\hline $\begin{array}{l}\text { MUMRER or } \\
\text { PMOTONS } \\
\text { STARTED } \\
\text { ISZJ2 }\end{array}$ & $\begin{array}{l}\text { TOTAL } \\
\text { MUMBEA or } \\
\text { coLLISIONS } \\
270 T \text { S }\end{array}$ & $\begin{array}{l}\text { OANDOM } \\
\text { NUMBERS } \\
\text { GENEAATEO } \\
\text { IOSIOS }\end{array}$ & $\begin{array}{l}\text { TOTAL } \\
\text { UETOMT } \\
\text { STAATED } \\
\text { I.SZ SEDOA }\end{array}$ & $\begin{array}{l}\text { TOTAL } \\
\text { ENEAGY } \\
\text { STAPTED } \\
\text { I. .4SGE.OA }\end{array}$ & $\begin{array}{l}\text { CELLISIOW- } \\
\text { ER PHOTLY } \\
\text { STARTED } \\
\text { l.7TISE•O1 }\end{array}$ & $\begin{array}{l}\text { TRACES } \\
\text { PER OKOTON } \\
\text { STARTED } \\
\text { O.25BEE.00 }\end{array}$ & $\begin{array}{l}\text { PHOTOHS } \\
\text { PROCESSED } \\
\text { PEA MINUTE } \\
\text { J.26OOE.OJ }\end{array}$ & \\
\hline $\begin{array}{l}\text { TotaL } \\
\text { TAACKS } \\
\text { STARTEO } \\
95303\end{array}$ & $\begin{array}{l}\text { Loss To } \\
\text { ENERGY } \\
\text { CuTOFF } \\
0\end{array}$ & $\begin{array}{l}\text { Loss ro } \\
\text { time } \\
\text { tuTofF }\end{array}$ & $\begin{array}{l}\text { Loss TO } \\
\text { uE IGNT } \\
\text { curorf } \\
14816\end{array}$ & $\begin{array}{l}\text { Los5 } \\
\text { In } \\
\text { Escop } \\
21670\end{array}$ & $\begin{array}{l}\text { LOSS } \\
\text { Po } \\
\text { SPLITTIMG } \\
\text { SB817 }\end{array}$ & $\begin{array}{l}\text { Toral } \\
\text { TaAcKs } \\
\text { Lost } \\
95303\end{array}$ & & \\
\hline $\begin{array}{l}\text { WE IGMT } \\
\text { SPADTED } \\
\text { PEA OHOTON } \\
1.0007 E=00\end{array}$ & $\begin{array}{l}\text { LOSS TO } \\
\text { ENEROY } \\
\text { EuTOFF } \\
\text { O. }\end{array}$ & $\begin{array}{l}\text { LOSS TO } \\
\text { IIME } \\
\text { cuTOFF } \\
0 .\end{array}$ & & $\begin{array}{l}\text { Loss } \\
\text { fo } \\
\text { ESCAPE } \\
3.20926001\end{array}$ & $\begin{array}{l}\text { Los5 } \\
\text { To } \\
\text { CAOTURE } \\
6.0201 E-0 .\end{array}$ & $\begin{array}{l}\text { WE IOHT } \\
\text { LOST } \\
\text { PER PMOTON } \\
1.0100 E .00\end{array}$ & & $\begin{array}{l}\text { PAIA } \\
\text { PRODJETION } \\
\text { PER PHOTON } \\
\text { I.JOISE-OZ }\end{array}$ \\
\hline $\begin{array}{l}\text { ENERGT } \\
\text { STAQTED } \\
\text { PEH PHOTON } \\
9.4027 E-01\end{array}$ & $\begin{array}{l}\text { LoSs To } \\
\text { ENERGY } \\
\text { CIJTOFF } \\
0 .\end{array}$ & $\begin{array}{l}\text { LOSS To } \\
\text { TIME } \\
\text { CUTOET } \\
0 .\end{array}$ & & $\begin{array}{l}\text { LOSS } \\
\text { Po } \\
\text { ESCAPE } \\
\text { T.5AIOE-OI }\end{array}$ & $\begin{array}{l}\text { LOSE } \\
\text { To } \\
\text { CADTUAE } \\
\text {. BOTOE OOP }\end{array}$ & $\begin{array}{l}\text { LOSS } \\
\text { TOPAIR } \\
\text { PRODUCTIOH } \\
\text { T.S! T9E-02 }\end{array}$ & $\begin{array}{l}\text { Loss } \\
\text { To } \\
\text { COMPION } \\
3.697 \mathrm{sE}-01\end{array}$ & $\begin{array}{l}\text { ENEAOT } \\
\text { LOST } \\
\text { PEA PKOTON } \\
9,4952 E=01\end{array}$ \\
\hline
\end{tabular}




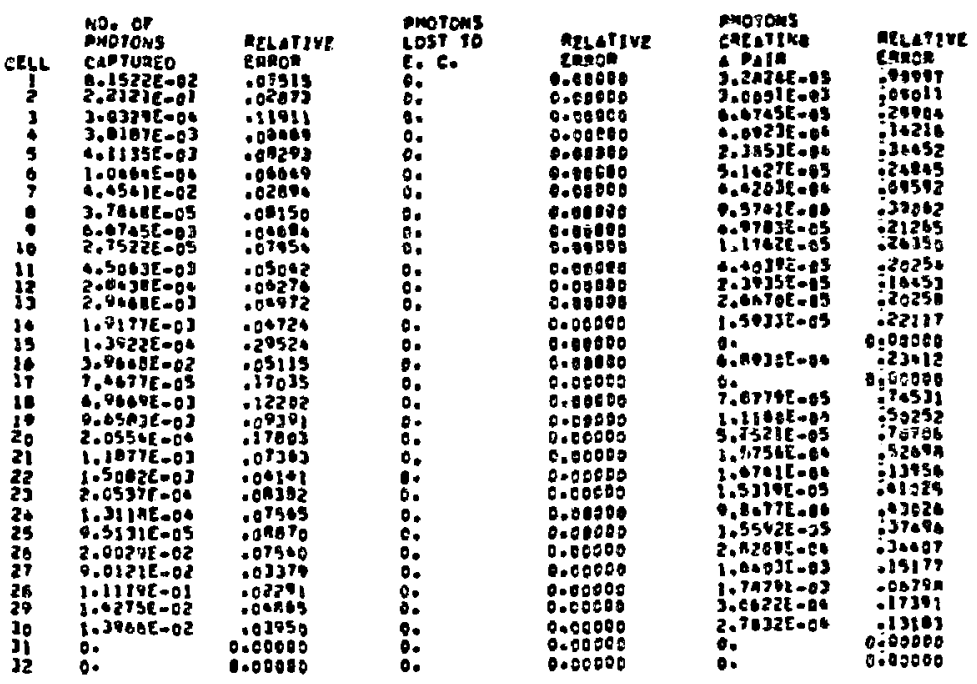

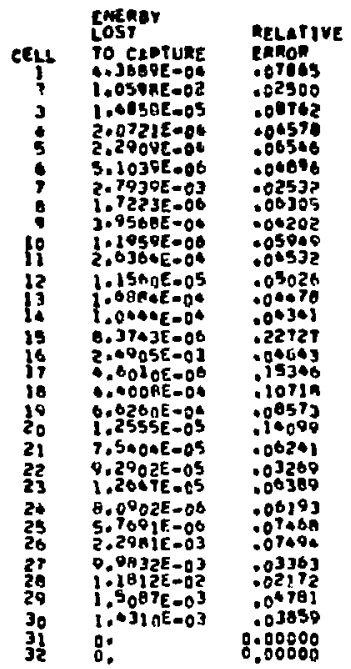

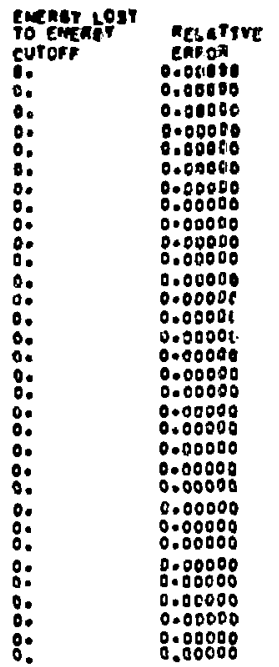

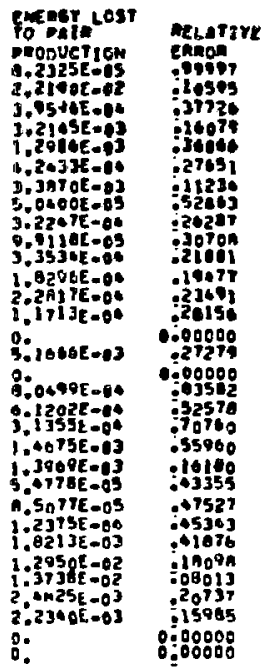

\begin{tabular}{|c|c|c|}
\hline 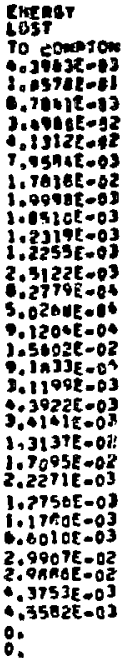 & 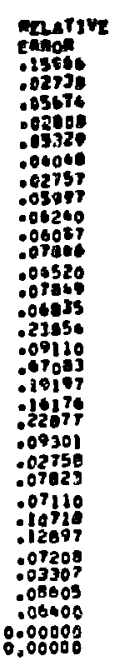 & 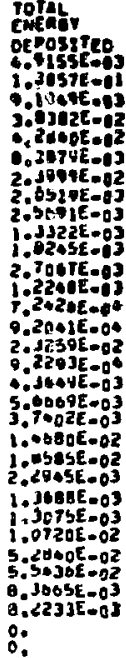 \\
\hline
\end{tabular}




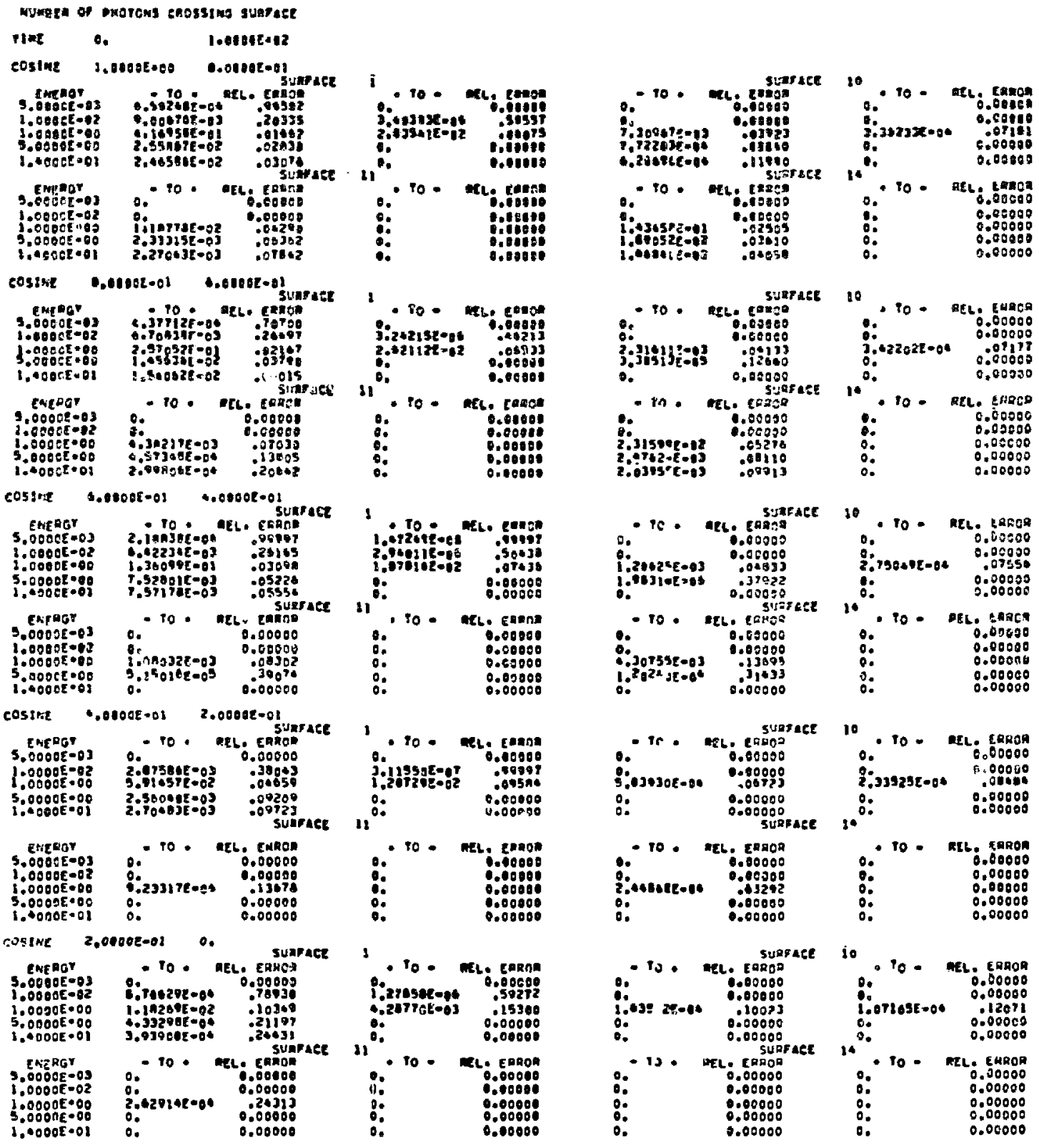


wumet rud Ihteansteo ovea suarace

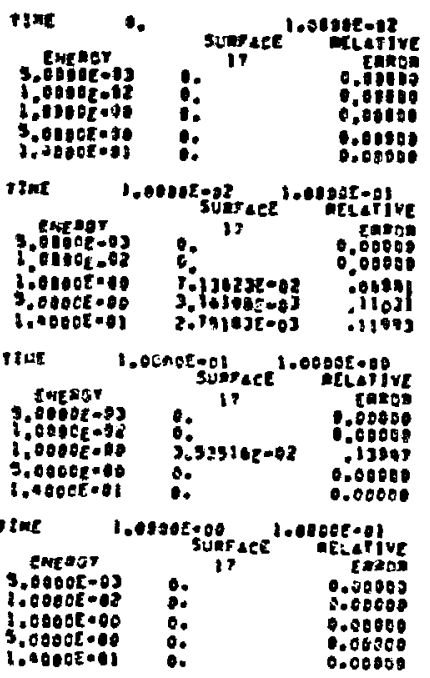

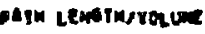

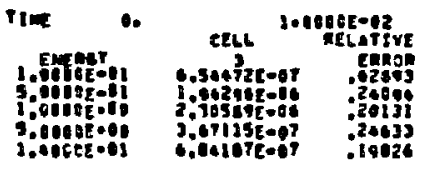

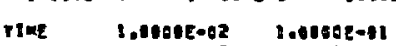

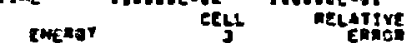

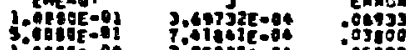
1,0usece 2,75ajted :05ta

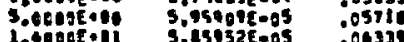

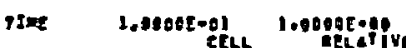

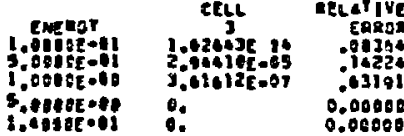

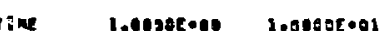

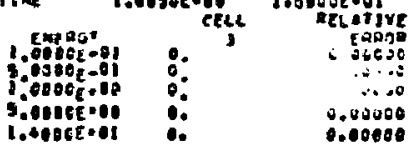

mume reul ap oerecton

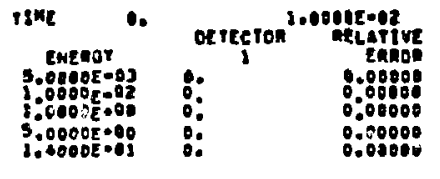

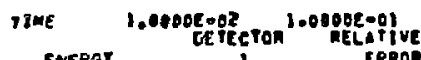

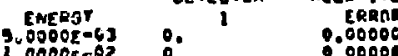

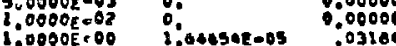

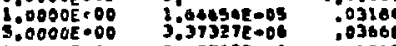

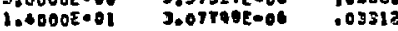
PIME 1.0000E-01 DETETOR l.0000E000

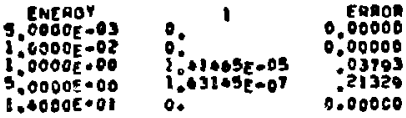
Itme $1.0000 E+00$ 1.0000E.01

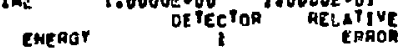
$\$ .0000 \mathrm{E}=03 \quad 0.100000$

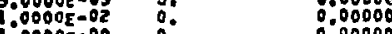
$\begin{array}{lll}1.0000 E+00 & 0 . & 0.00000 \\ 5.0000 E+00 & 0 . & 0.00000\end{array}$ $\begin{array}{lll}5.0000 E+00 & 0 . & 0.00000 \\ 1.0000 E+11 & 0 . & 0.00000\end{array}$ 


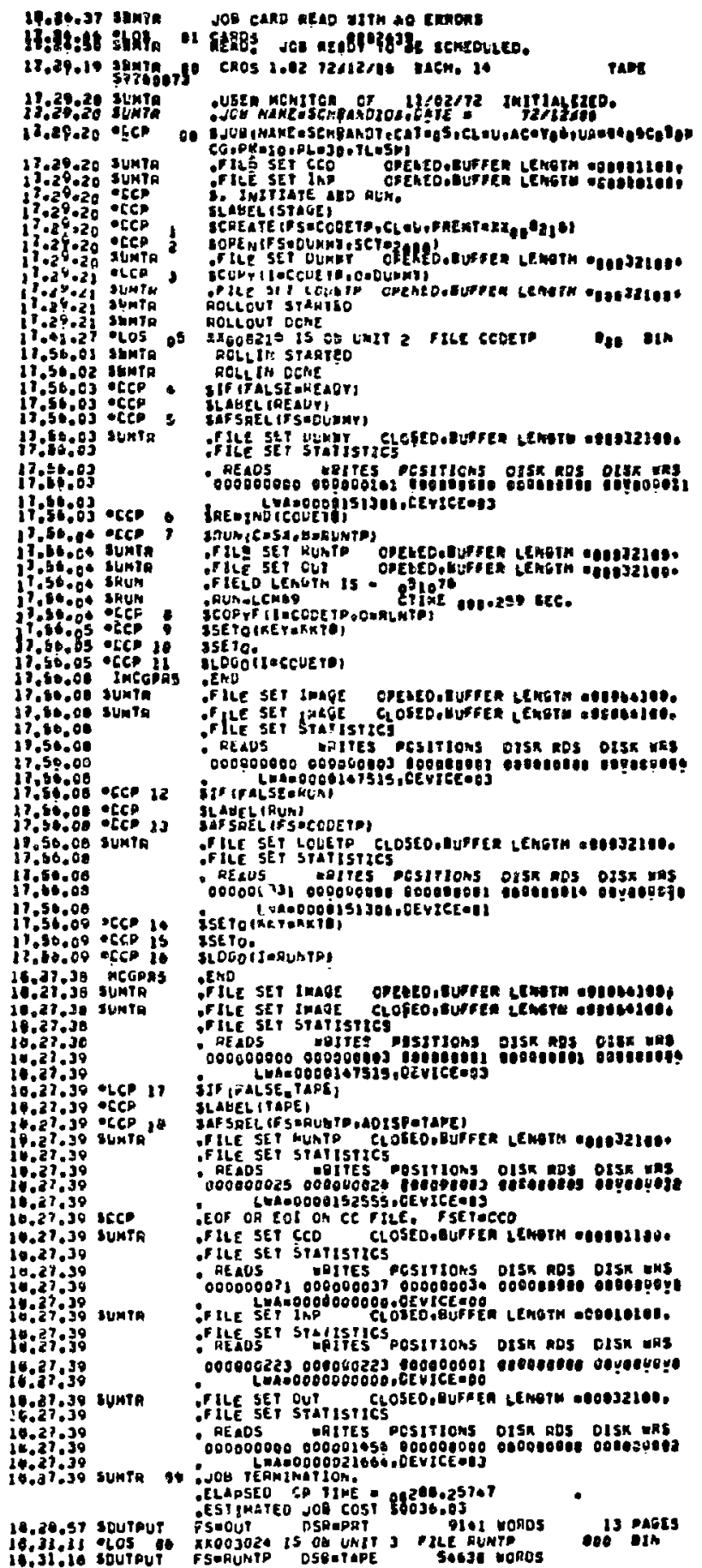

gILE COMPLETE scmandoto I 


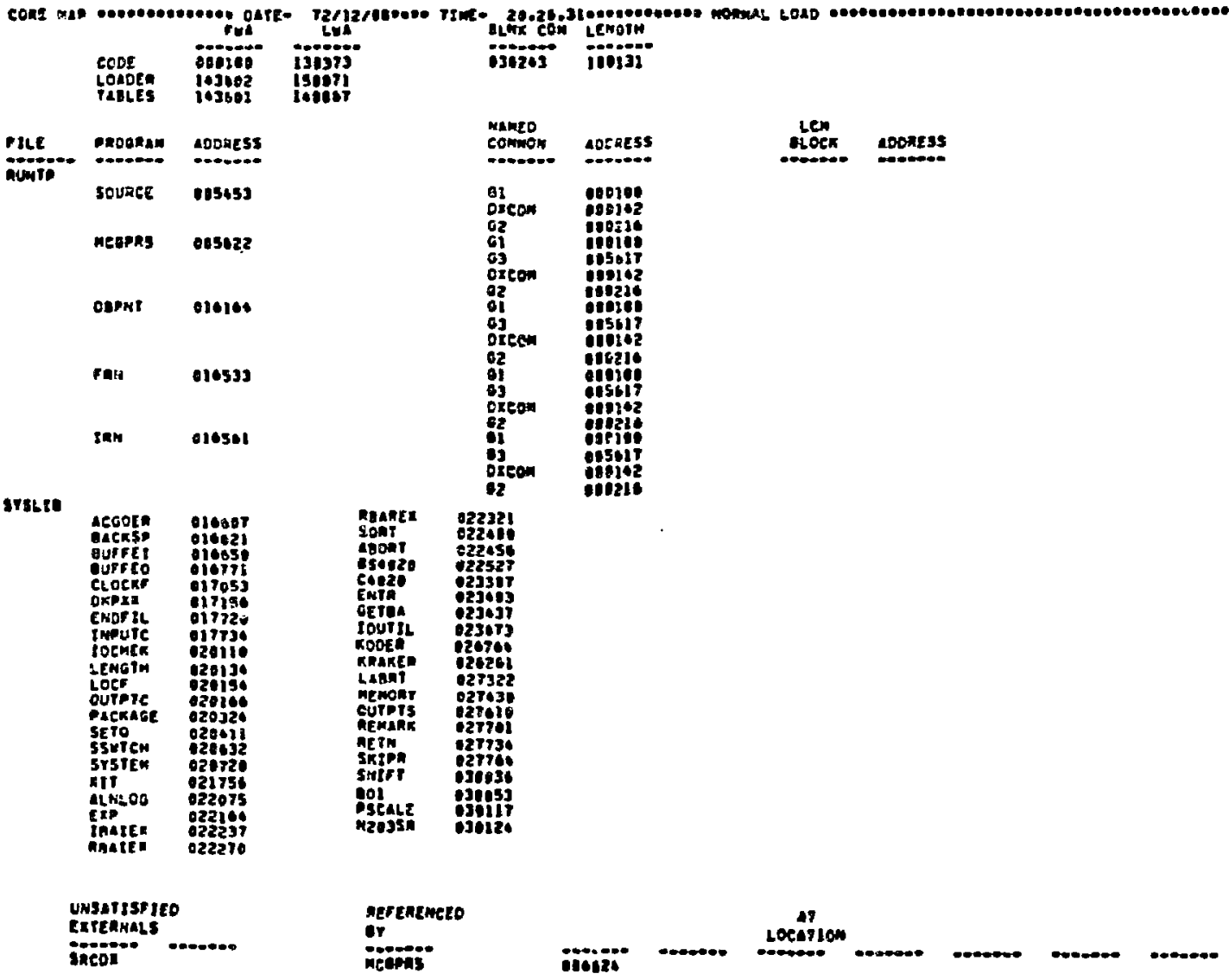

nce rest mollem

\begin{tabular}{|c|c|c|c|c|c|c|c|c|}
\hline soukee wo & $\begin{array}{l}\text { TIm cutofr } \\
\text { logsese }\end{array}$ & $\begin{array}{l}\text { T. Cutcfi I } \\
\text { I.0sest-03 }\end{array}$ & $\begin{array}{l}\text { nut rint } \\
\text { G.90อง }\end{array}$ & $0.0:$ Crel $_{1000}$ & $\begin{array}{l}\text { Dump erele } \\
\text { soues }\end{array}$ & oum & eurort erese & 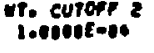 \\
\hline \multicolumn{9}{|c|}{ Irate $\$ .3 / 9$ msmutes } \\
\hline $\begin{array}{l}\text { MUMAER of } \\
\text { PHOTONS } \\
\text { STARTEO } \\
\text { JOLO }\end{array}$ & $\begin{array}{l}\text { Toral } \\
\text { muger of } \\
\text { collistons } \\
\text { so3ere }\end{array}$ & $\begin{array}{l}\text { Pampos } \\
\text { nuwheas } \\
\text { gewethatco } \\
\text { grieas }\end{array}$ & 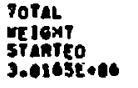 & $\begin{array}{l}\text { rotal } \\
\text { encagr } \\
\text { stanteg } \\
\text { 2.toogego }\end{array}$ & 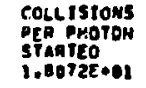 & 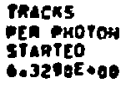 & $\begin{array}{l}\text { Puorons } \\
\text { pmocessco } \\
\text { Per nimute } \\
\text { j.zovicos }\end{array}$ & \\
\hline $\begin{array}{l}\text { Total } \\
\text { raAcins } \\
\text { stapteo } \\
\text { loasos }\end{array}$ & $\begin{array}{l}\text { LoSS TO } \\
\text { EAERGY } \\
\text { CUTOFF }\end{array}$ & $\begin{array}{l}\text { loss ro } \\
\text { tint } \\
\text { cutore }\end{array}$ & $\begin{array}{l}\text { Loss to } \\
\text { yefent } \\
\text { cutort } \\
\text { eots2 }\end{array}$ & $\begin{array}{l}\text { loss } \\
\text { to } \\
\text { Estape } \\
42723\end{array}$ & $\begin{array}{l}\text { coss } \\
\text { To } \\
\text { spltTINe } \\
12810\end{array}$ & $\begin{array}{l}\text { Total } \\
\text { tancks } \\
\text { Lost } \\
\text { doasos }\end{array}$ & & \\
\hline 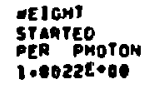 & $\begin{array}{l}\text { Loss } 10 \\
\text { ENERGY } \\
\text { EuTor } \\
\text { o. }\end{array}$ & $\begin{array}{l}\text { Loss ro } \\
\text { 7tike } \\
\text { cutore } \\
\text { o. }\end{array}$ & & $\begin{array}{l}\text { Loss } \\
\text { ro } \\
\text { Escapt } \\
\text { J.2723t-01 }\end{array}$ & $\begin{array}{l}\text { Lo5s } \\
\text { To } \\
\text { cAPruAE } \\
\text { C.OS12E-OI }\end{array}$ & 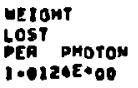 & & $\begin{array}{l}\text { PAtR } \\
\text { PROOUCTION } \\
\text { PEA PHOTON } \\
\text { P.3OTOE-OS }\end{array}$ \\
\hline $\begin{array}{l}\text { Emenor } \\
\text { stanteo } \\
\text { Pen PKoton } \\
\text { P.JISTE= }\end{array}$ & $\begin{array}{l}\text { Loss ro } \\
\text { cwengy } \\
\text { cutofy } \\
\text {. }\end{array}$ & $\begin{array}{l}\text { coss } 70 \\
\text { five } \\
\text { eutot: } \\
\text { o. }\end{array}$ & & 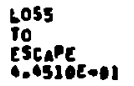 & $\begin{array}{l}\text { loss } \\
\text { To } \\
\text { tapruAE } \\
\text { G, oobet-02 }\end{array}$ & 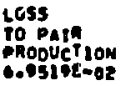 & $\begin{array}{l}\text { less } \\
\text { To } \\
\text { compron } \\
\text { J.6este-el }\end{array}$ & 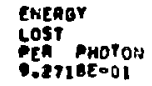 \\
\hline
\end{tabular}




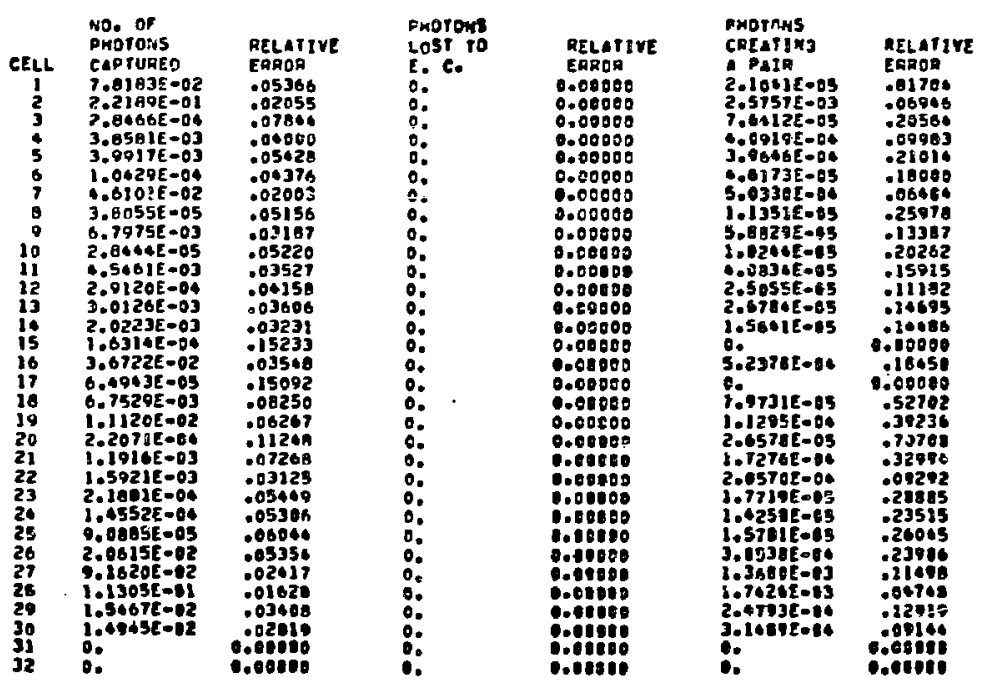

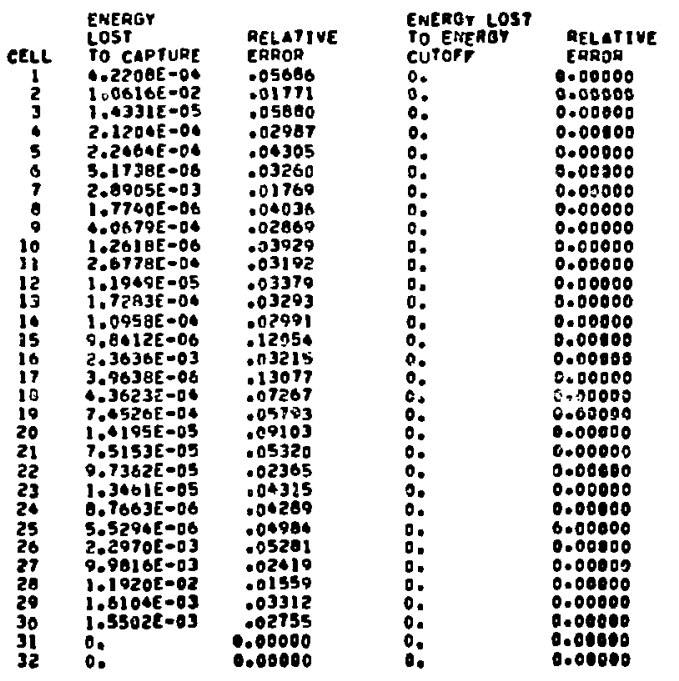

\begin{tabular}{|c|c|}
\hline 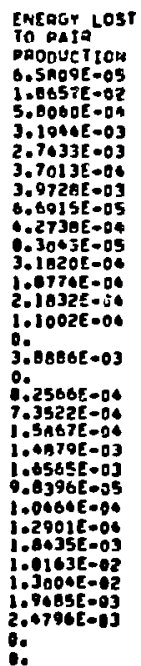 & 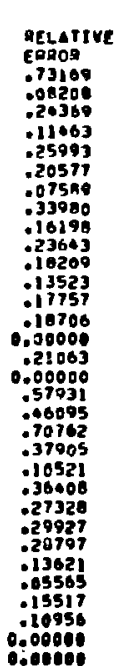 \\
\hline
\end{tabular}

\begin{tabular}{|c|c|c|}
\hline 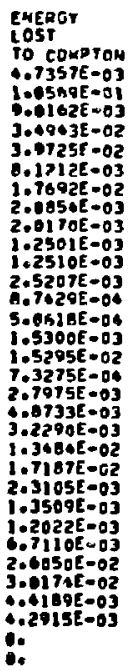 & 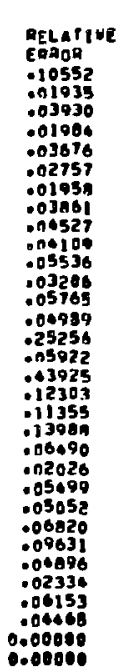 & 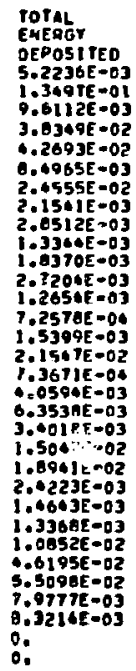 \\
\hline
\end{tabular}


Mumger of motons crossing SuAface

TIME $0.100000 \bullet 02$

COSINE 1.0000E000 0.0000E-01

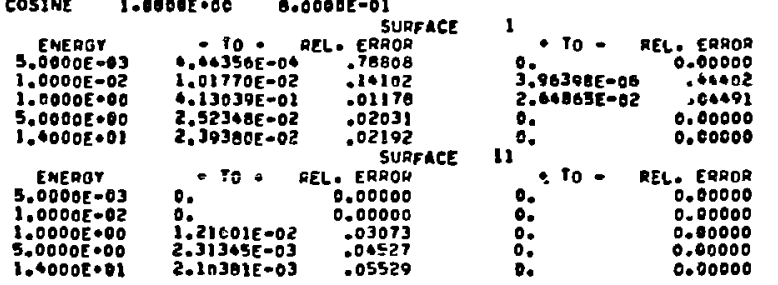

\begin{tabular}{|c|c|c|c|}
\hline $\begin{array}{l}-10 . \\
27895 E=0 \\
59691 E=0\end{array}$ & $\begin{array}{c}\text { SURFACE } \\
\text { REL. ERROR } \\
0.00000 \\
0.00000 \\
0.02762 \\
3.06270 \\
.08670\end{array}$ & $\begin{array}{l}10 \\
0 . \\
0: \\
30.4061 E=0 \\
0 . \\
0 .\end{array}$ & $\begin{array}{r}\text { ELL ERROR } \\
0.00000 \\
0,00000 \\
.04885 \\
0.00000 \\
0.00000\end{array}$ \\
\hline 85 & $\begin{array}{rl} & \\
& 0.0 \\
0.0 & 0 \\
1 & 0.0 \\
2 & : 0 \\
2 & : 0\end{array}$ & $\begin{array}{l}: \\
0: \\
0: \\
0: \\
0 .\end{array}$ & $\begin{array}{r}\text { REL ERAOR } \\
0.00000 \\
0.00000 \\
0.00000 \\
0.00000 \\
0.00000\end{array}$ \\
\hline
\end{tabular}

CosINe B.0000E-0I 6.0000E-01

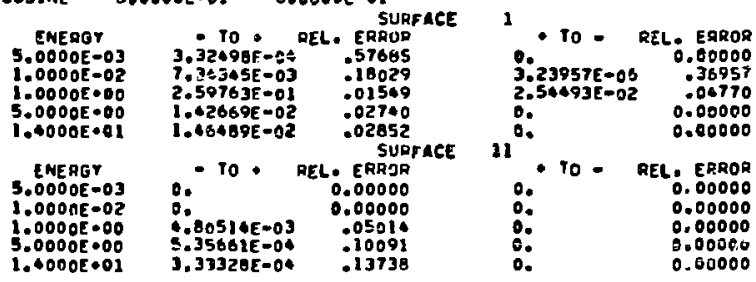

COSINE $6.0000 E-01 \quad 40000 E-01$

COSINE $6.0000 E-01 \quad 4.0000 E-01$
ENERGY

\begin{tabular}{|c|c|c|}
\hline $\begin{array}{l}\text { ENERGY } \\
5.0000 E=03 \\
1.00000=02 \\
1.0000 E=00 \\
5.0000 E 000 \\
1.40000001\end{array}$ & 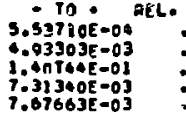 & $\begin{array}{l}\text { E9ROR } \\
.66330 \\
.20075 \\
.02178 \\
.03798 \\
.03918\end{array}$ \\
\hline
\end{tabular}

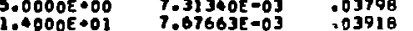

EMEOSY

S. DONOE $=03$

$5.0000 E-63$
$1.0000 E-02$

$1.0000 E-02$
$1.0000 E \bullet 00$

S.0000E 1.000

- TO - REL. ERAOR

- TO REL. ERROR

$\begin{array}{ll}0.10 & 0.00000 \\ 0.00000\end{array}$

$1.00318 E-03 \quad .05927$

$\begin{array}{lll}7.21665 E-05 & \$ 26763\end{array}$

COSINE 4.0000E-01 2.0004E-01

T.000E-01 $2.0000 E-01$ SUAFACE

ENERG

S. OOOOE-0.

$1.0000 E-02$

- TO - REL ERAOR

$\begin{array}{lr}0 . & 0.00000 \\ 2.23921 E-03 & .32818\end{array}$

$\begin{array}{ll}2.23921 E-03 & .32818 \\ 6.07369 E-02 & .03338 \\ 2.706008-03 & .06306\end{array}$

$\begin{array}{ccc}5.0000 E \cdot 00 & 2.74640 E-03 & .06386 \\ 1.0000 E \cdot 01 & 2.55592 E-03 & .06827 \\ \text { SUAFACE }\end{array}$

EAEQGY

S.0000E-03

$1.0000 E=02$
$1.0000 E$

$9.0000 \% 000$

- TO REL. ERAOR

$0.00031 E-04 \quad 0.0000$
.09367

$5.51576 E=06 \quad 0.99908$
0.

COSINE 2.0000E-01 0.

1 . TO - AEL. ERACR

T. TS106E-00 AEL. ERACR
,99508

$\begin{array}{ll}1.09250 E-06 & .50265 \\ 1.77135 E-02 & .05290\end{array}$

$1.77135 E-02 \quad 005290$

$\begin{array}{ll}0 . & 0.00000 \\ 0 . & 0.00000\end{array}$

11 . TO. REL. ERROR

$\begin{array}{lr}0 . \text { TO } & \text { REL. ERROR } \\ 0.00000 \\ 0 . & 0.00000 \\ 0 . & 0.00000 \\ 0 . & 0.00000 \\ 0.000000\end{array}$

1 - TO - AEL, ERROR

$0.10251 E=07 \quad 0.00000$
$1.9269 ?$

$1.29900 \mathrm{0}-02 \quad .06746$

$\begin{array}{ll}1.29900 E-02 & .06746 \\ 3.65432 E-05 & .75269\end{array}$ 10.

$\begin{array}{lr}0 . \text { TO REL. ERROR } \\ 0.00000 \\ 0 . & 0.00000 \\ 0.00000 \\ 0.0 & 0.00000 \\ 0.000000\end{array}$

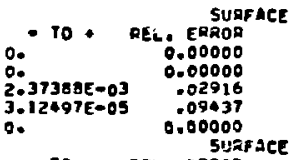

- to - REL ERRoR

0.

$\begin{array}{ll}0 . & 0.00000 \\ 2.47377 E-02 & .00000 \\ 0.03742\end{array}$

$2.386698-03 \quad .05806$

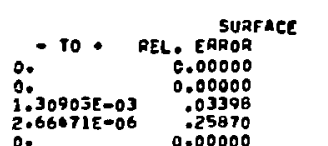

0.00000
SURFACE

- TO - DEL. ERaOR

$0 . \quad 0.00800$

$0.000035=03 \quad 0.00000$

$0.32093 E=03$
$1.02905 E=06$

$1.02905 E-04 \quad .26630$

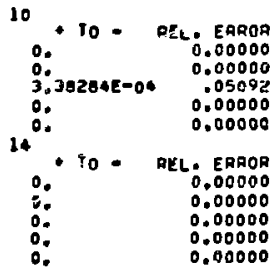

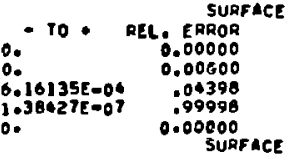

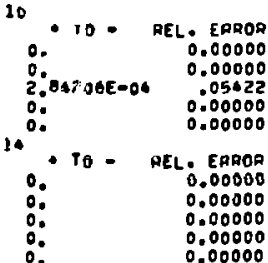

ENEPG

ENEPG
S. 00ODE

$3.0000 E-03$
$1.0000 E-02$

$1.0000 \mathrm{0} 00$

1. 4000 001

- TO - REL E ERROR

$1.20742 E-04$ REL + ERROR

$\therefore .55192 E-04 \quad$.78661

$\begin{array}{ll}1.140335-02 & .07209 \\ .352106-06 & .15019\end{array}$

$\begin{array}{ll}0.352186-06 & 15019 \\ 3.05302 E-06 & 17155\end{array}$

- To PEL. SUPfaCE

ENEROY

$5.0000 E=03$
$1.0000 E=02$

$1.0000 E=02$

5.00005 .00

- TO REL. EAROD
0,00000

$\begin{array}{ll}0 . & 0.00000 \\ 0.0 & 0.00000\end{array}$

2.10563E-04 .16192

.00000
.00000

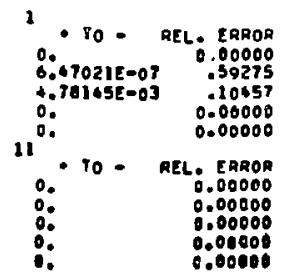

O. TO PEL. ERROR

3.06798E-04 0.00000

$0 . \quad 0.00000$

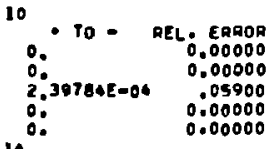

$\begin{array}{rr}0.010-R E L \text { ERROA } \\ 0.00000 \\ 0 .: & 0.00000 \\ 0.00000 \\ 0.0 & 0.00000 \\ 0.0 & 0.00000\end{array}$

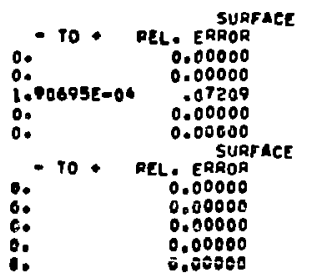

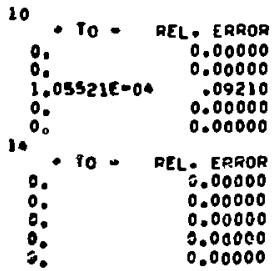


NUMBED FLUX INTEORATEO OYER SURFACE

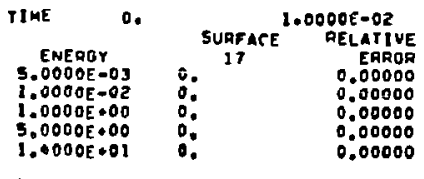

TIME $1.0000 E=02 \quad 1.0000 E-01$

\begin{tabular}{|c|c|c|}
\hline $\begin{array}{l}\text { ENEAGY } \\
5,0000 E-03 \\
1.0000 E=02 \\
1.0000 E-00 \\
3.0000 E \cdot 00 \\
1.00000 .01\end{array}$ & $\begin{array}{l}0.17 \\
0: 5 \\
7: 15071 E=02 \\
3.946 A B E=03 \\
2.79990 E=03\end{array}$ & $\begin{array}{r}\text { ERROR } \\
0.00000 \\
0.00000 \\
.04036 \\
.07400 \\
.08408\end{array}$ \\
\hline
\end{tabular}

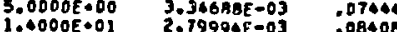

IIME $1.0000 E-01 \quad 1.0000 E 000$

EMEQTY SURFACE RELATIVE

ERROD

$\begin{array}{lll}5.0000 E-03 & 0 . & 0.00000\end{array}$

$1.0000 E+00 \quad 3.79357 E-02 \quad 0,000378$

$5.0000 E+00$ 0.

IIME 1.0000 .00 $1.0000 E 001$

ENERG SUAFACE RELATIVE

E 03 I7

$\begin{array}{lll}5.0000 E-03 & 0 . & 0.00000 \\ 1.0000 E=02 & 0 . & 0.00000\end{array}$

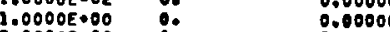

$\begin{array}{lll}\$ .0000 E .00 & 8 . & 0.00000 \\ 1.0000 \varepsilon .01 & 0.00000 & 0.00000\end{array}$ path lemoth/nollha

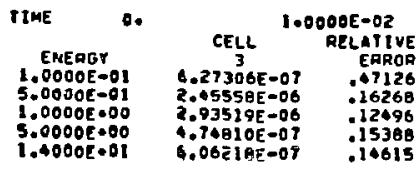

TIKE 1.00005-0Z 1.0000E-01

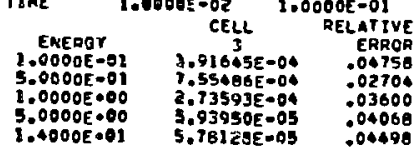

T.0.000E

TIAE 1.0000001 1.2000E.00

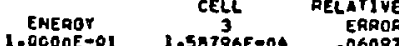

$\begin{array}{lll}1.0000 E-01 & 1.53796 E-04 & .06097\end{array}$

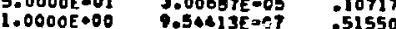

$\begin{array}{lll}5.0000 E \cdot 00 & 0.51550 \\ 1.20002 .01 & 0.00000\end{array}$

TIKE $1.0001 E \bullet 00 \quad 1.0000 E+01$

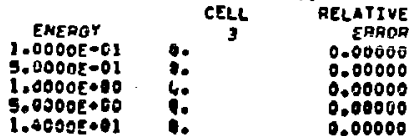

NUHAER FlUK at UETECTOR

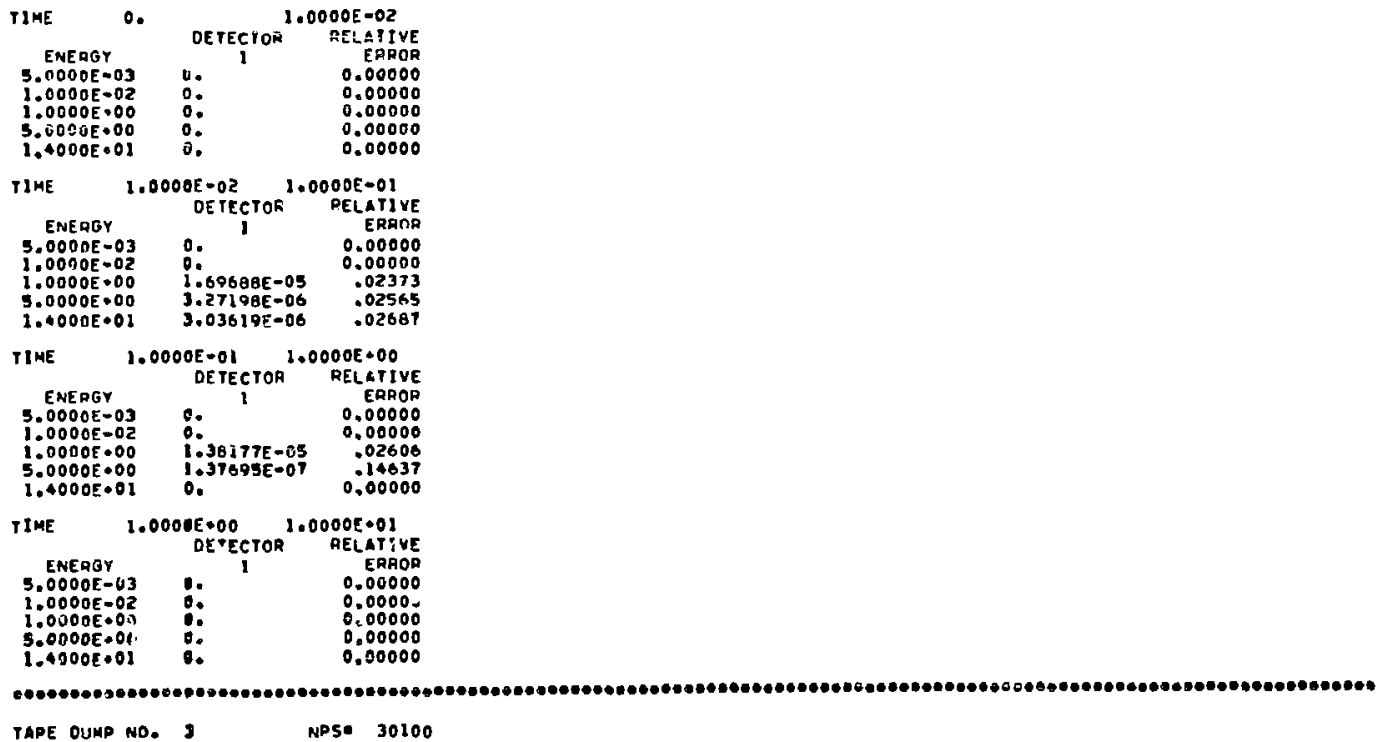




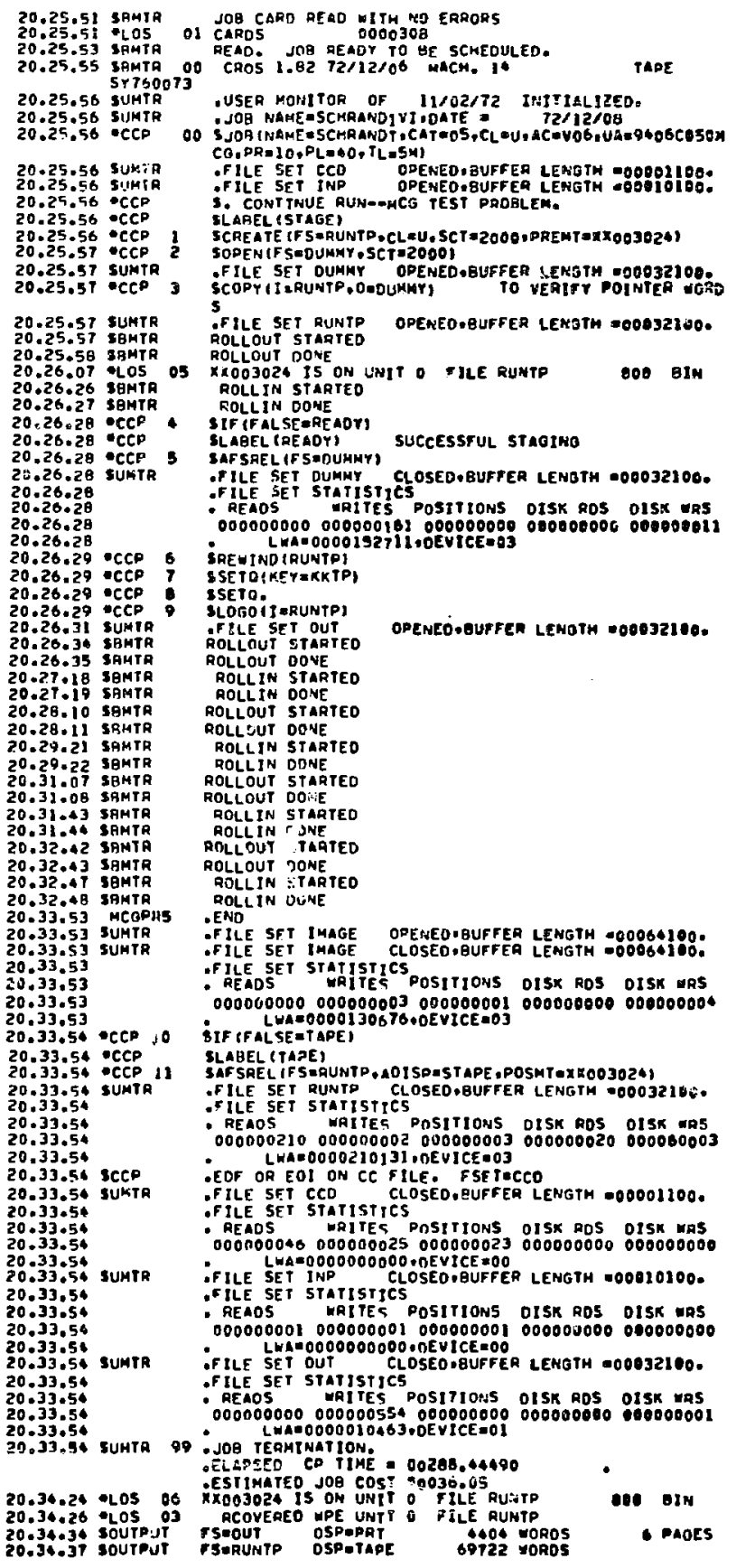

, ILE COMPlETE SCMAMNDIVI $?$ 
TABLE V

SAMPLE RUN - MCP

10

2

24

52

57

60

6

SURGOUTINE SUUACE

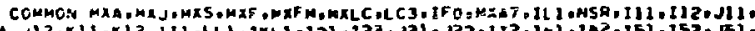

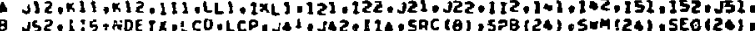

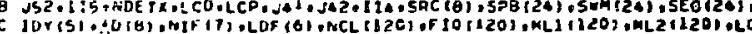

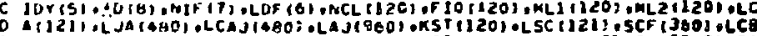

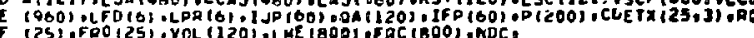

B NST, XAN ONAN, TOS

1

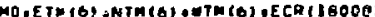

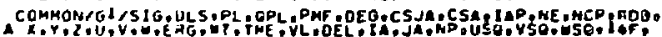

B 11F,I TR, 15F, 16F

COMMON/(S5) JO(2), 1P (25), J5\$ (120),501 (120),562 (120), TCR(15),

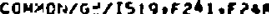

Common

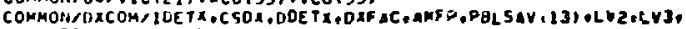

UNIF OHMLY OISTAIHUTED IN YCLLKE IM SPECITIEO SPHEAICAL EELL.

C STHETIRS UIRECTIOH ISOREDIC, BUT BIASED IN DOSITIVE VEOIREETIOM.

ENEHGT DISTAZBUTION.

ST CARO DE QUTREO IN PROBLEM DECK.

SRC (J)-CELL MUHAER.

SAC (2) DUABIUS OF CELL IA CM.

SHCIJI IFPACTION OF AEUTGOHS UMOSE STARTING DIRECTION WAS POSITIVE $\mathrm{Y}$.

UISTANCE FROH ORIGIN SANPLED FDON THE IHTERVAL O.SRCIZII

UISTRIHUTEO ACCOROLNG TE TME DISTAMCE CUBEO.

SAMPLE INAITORMLY FROM POINIS INSIDE THE UNIT CIDCLE.

10 TPIII-5.AFRN $(K R M)-1$

TP(2) $=2$, OFAN (KRN) -1

$I P\{3)=I P[1]=5 \cdot T P(2) \cup 5$

C TP (3) DESTRI HUTED UHIFORML OW THE IMTEqYal 10.11.

THe cosine of the POLAR antle of tre startino point.

TP(4) $2.0 T P(3)-10$

TP(S)=RESORT (I).-IPIA)

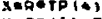

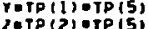

1. (FRN (KRN) . OT . 5AC (3), OO TO 30

SET V FOSITIVE SAĆ(3) OF THE TIME.

VOABS(V)

5 isesocis

IA $=5$ SAC I

TME $=0$

VEL $=0$

AEFRnIKAN)

DO 20105.0

IF (A) $L$ T. SPa(1)) 00 to 25

25 EHGASEO $(1-1)-(S E O(1)-5 E \theta(1-1))$ - (A-SPB $(1-2))$,

1 (SPE II) $-5 P B \mid 1-11)$

Minteswa(t)

RE TURN

SET Y HEQATIVE i-SRC(3) OF THE IIME,

Jo ve-absivi

$-1=0.5 / 1+0-5 R(13) 1$

GO TO 15

END 


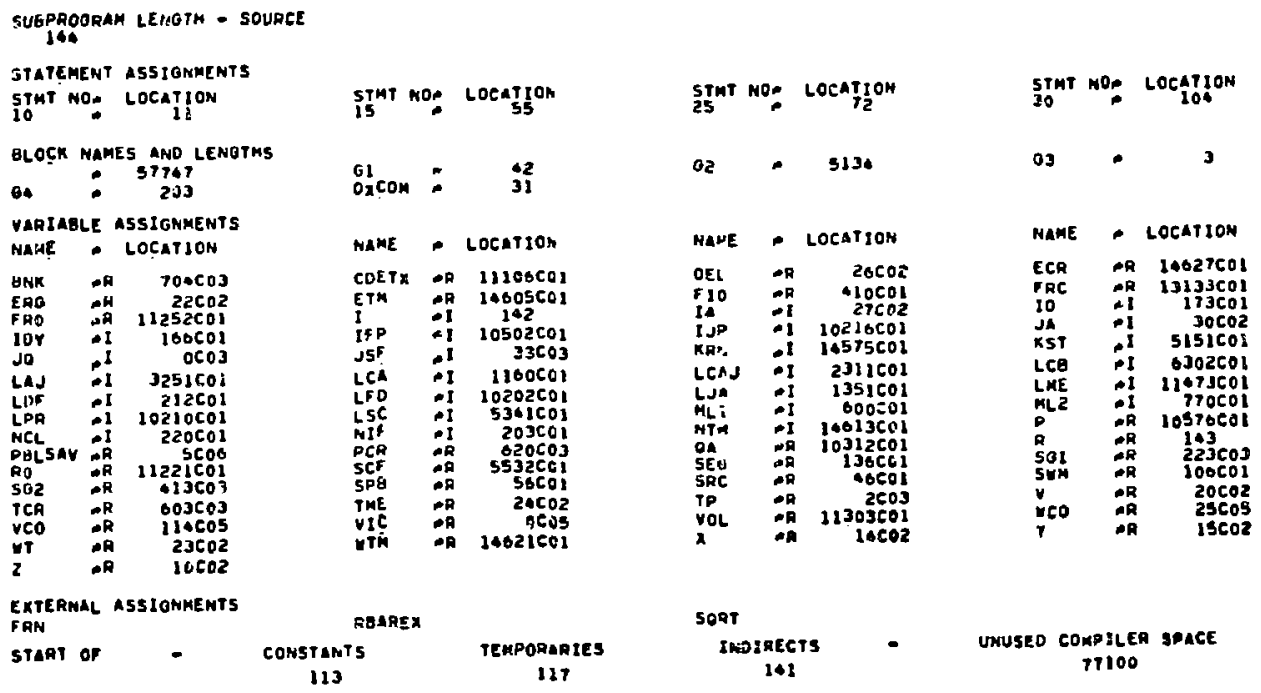

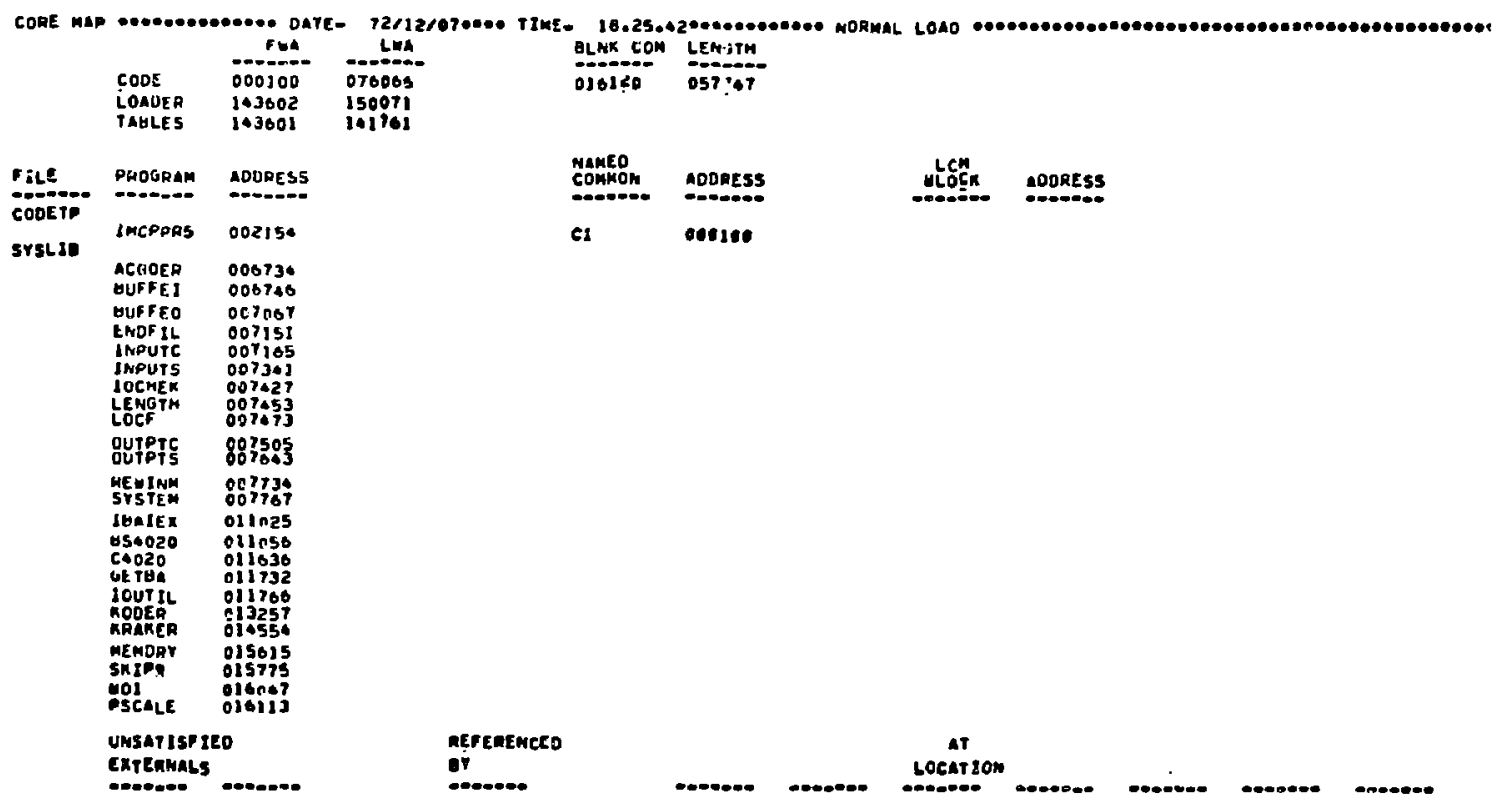



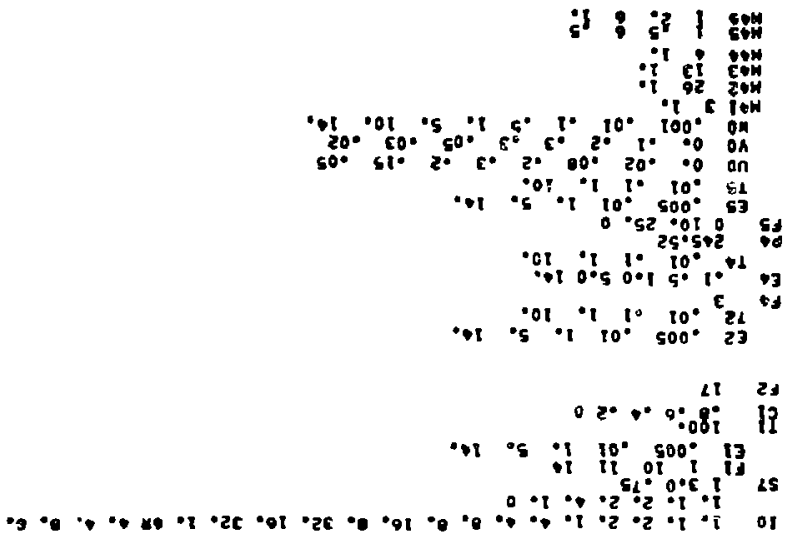

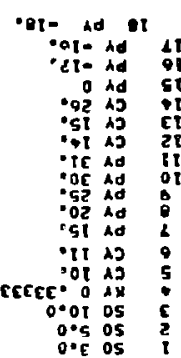

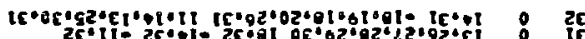

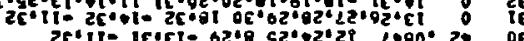

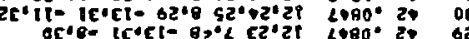

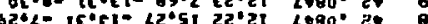

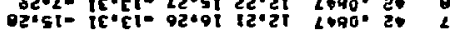
L50, IE.

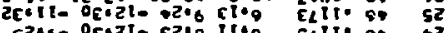

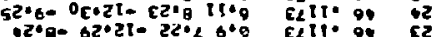

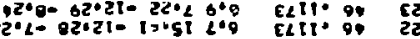

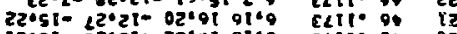

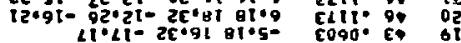

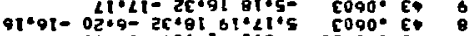

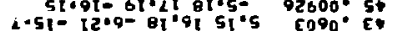

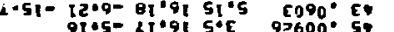

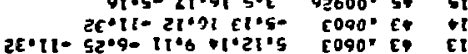

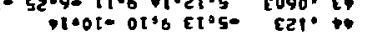

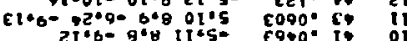

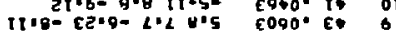
$070-9.46+5=$ c940. It Q

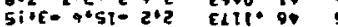

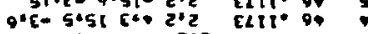

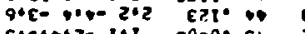


HO. CELLS• 32

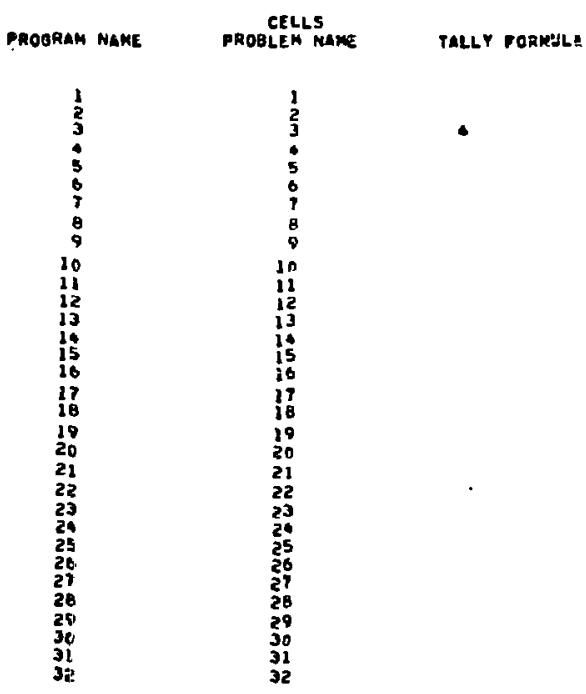

Fo. SURFACESO 20

SUAF ACES

PROQLEH MAKE

TAlLY TORMULA

progana game

\begin{tabular}{|c|c|c|c|c|}
\hline $\begin{array}{c}\text { Cethl } \\
1 \\
2 \\
3\end{array}$ & AMB. SURF, & $\begin{array}{l}\text { MATEATAL } \\
45 \\
\$ 3\end{array}$ & $\begin{array}{c}\text { OENSITY } \\
9.21 \text { JOE-0. } \\
\text { Q.gJOgE-02 } \\
1.2 E J 0 E=01\end{array}$ & $\begin{array}{l}10 \\
1.0000 E=00 \\
1.00000=00 \\
2.0000 E\end{array}$ \\
\hline 5 & & 46 & $\{: 17390=01$ & Z.0000E \\
\hline $\begin{array}{l}6 \\
7 \\
9\end{array}$ & & $\begin{array}{l}41 \\
43 \\
41\end{array}$ & $\begin{array}{l}4.63 n 0 E-02 \\
6.0300 E=02 \\
.0270 E=02 \\
0.0300 E-02\end{array}$ & $\begin{array}{l}\$, 0000 E * 00 \\
+0000 E=00 \\
+0000 E+00 \\
.0000 E-00\end{array}$ \\
\hline $\begin{array}{l}10 \\
11 \\
12 \\
13 \\
14 \\
15 \\
16 \\
17 \\
16 \\
19 \\
20 \\
21 \\
22 \\
23 \\
24 \\
25 \\
26 \\
27 \\
28 \\
29 \\
30 \\
31 \\
32\end{array}$ & & $\begin{array}{l}41 \\
43 \\
44 \\
43 \\
43 \\
45 \\
43 \\
45 \\
43 \\
43 \\
46 \\
46 \\
46 \\
46 \\
46 \\
46 \\
42 \\
42 \\
42 \\
42 \\
0 \\
0\end{array}$ & 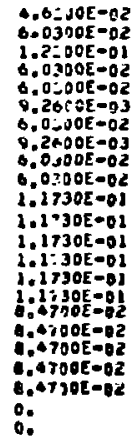 & 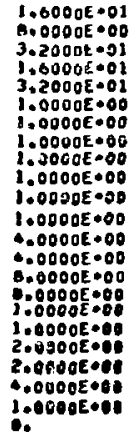 \\
\hline
\end{tabular}

FORMULA 3 OO NEUTRONS CROSSINO SUAFACE

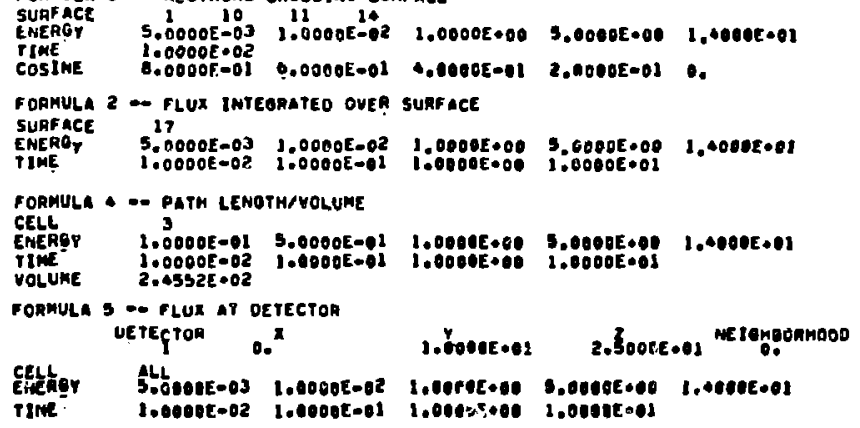




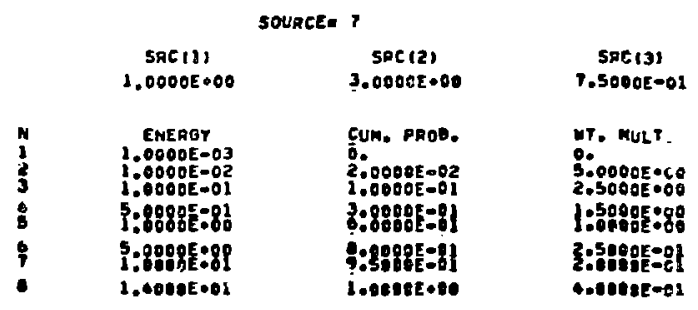

material oata

\begin{tabular}{|c|c|c|}
\hline $\operatorname{mat.}_{4 i}^{\text {no. }}$ & $\operatorname{ELEM}_{3}$ MO! & $\begin{array}{l}\text { Fract tom } \\
1.00000\end{array}$ \\
\hline MaT. NO. & $\underset{26}{\text { KLEM, }}$ & $\begin{array}{l}\text { Fanetion } \\
1.00000\end{array}$ \\
\hline mat; No, & ELEM, $_{13}{ }^{\text {MO: }}$ & $\begin{array}{l}\text { Fracrioh } \\
1.000000\end{array}$ \\
\hline mate no. & ELEE: NOE & $\begin{array}{l}\text { SaActrow } \\
\text { 1.000000 }\end{array}$ \\
\hline mat: NO. & $\operatorname{ELEM}_{i}{ }^{\text {NOE }}$ & $\begin{array}{l}\text { raserzom } \\
\text {-50000 } \\
.55000\end{array}$ \\
\hline MAT: NO. & 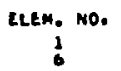 & $\begin{array}{l}\text { foraction } \\
\text {.66667 } \\
.33333\end{array}$ \\
\hline
\end{tabular}

INITIATION COMPLETED 


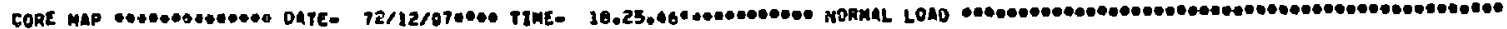
COPE BLHK COK LENOTH

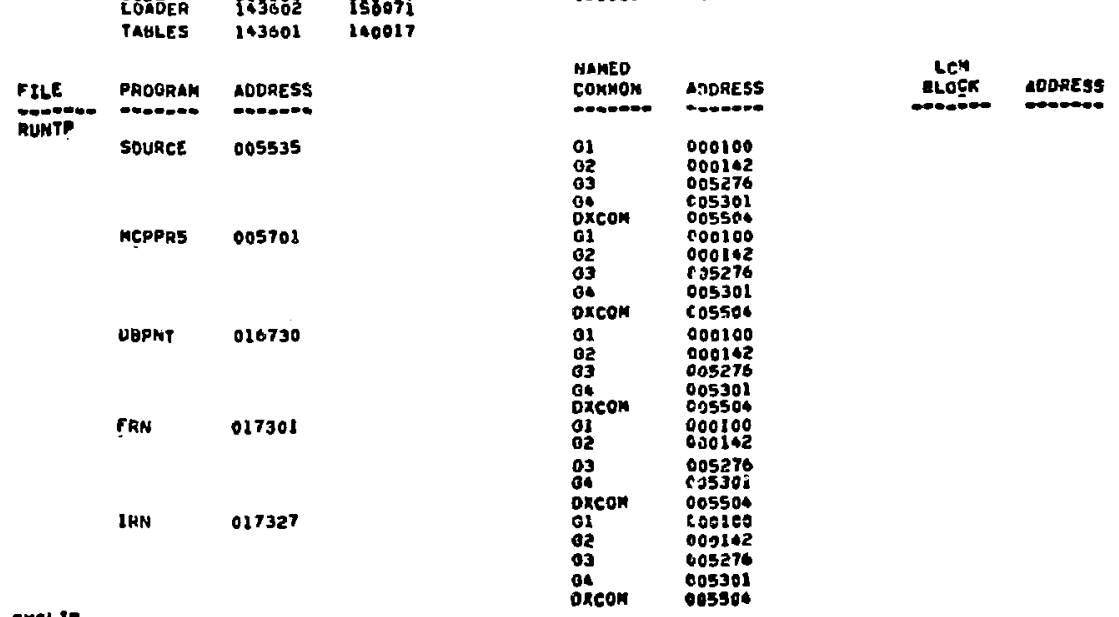

STSLIB ACGER OL7355

$\begin{array}{ll}\text { ACGUER } & 027359 \\ \text { UACKSP } & 017367\end{array}$

UUFFEI OI7०16

UUfFEO 017537

CLOCKF 01782?

ERf

JNPUTC 020502

DOCHEK 020656

LENGTh 020702

OCF 020722

OUTPTC 02073

Packnoe $021 \mathrm{nt}$

S5UTCH 021600

SYSTEM 021466

ALMLOO 022643

Ituilex 0z3nos

Roulex 023036

RGAREX 023067

SARP

aront 023224

$\begin{array}{ll}04020 & 023275 \\ 6 & 020055\end{array}$

CNTR

GETBA 024205

IOUTIL O2424I

KOOER 025532

KRAKER OZTHZT

GAYRT 830070

OUTPYS 030356

REMARK 030447

HETP

SNIPR OJNST

Swirr 03080

Pscale

N2035R 030672

UNSATISFIED

UNSATISF IED

Ret TREnCEO

spCDX

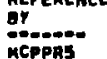

AT

nCppas

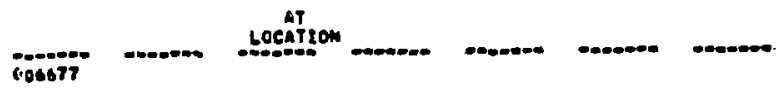




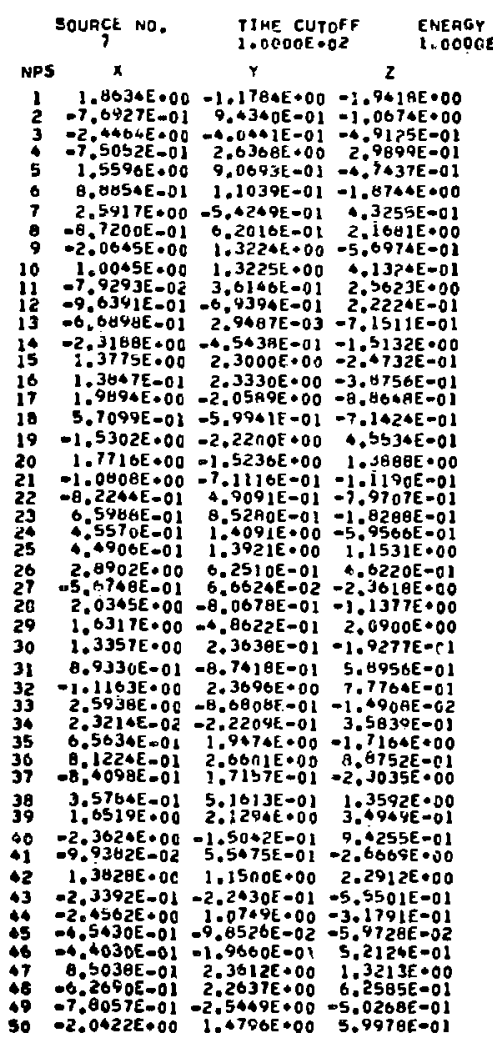

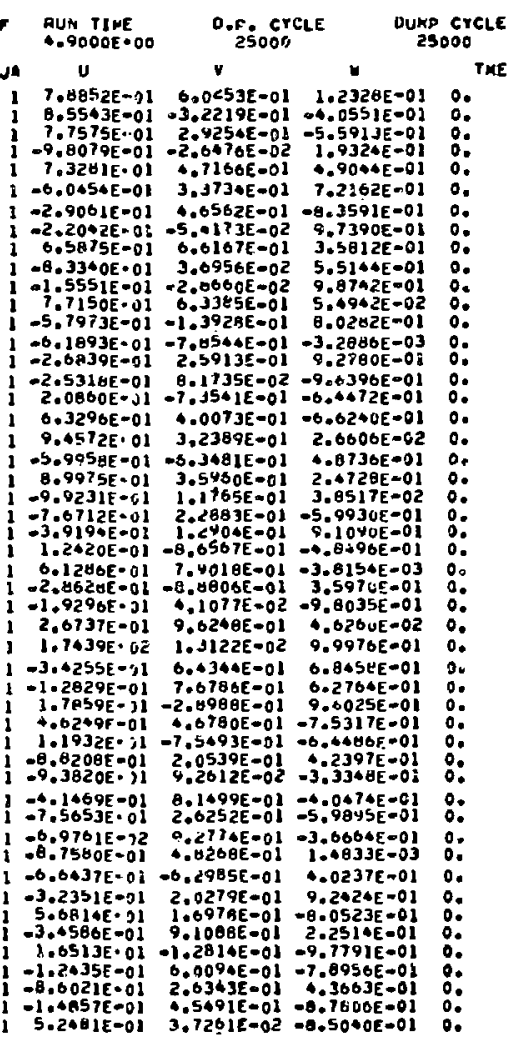

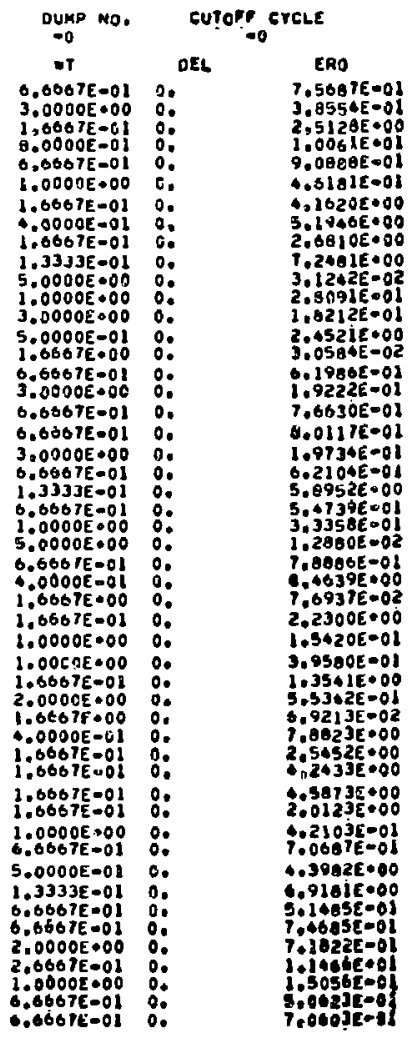

MCP TEST PROQLEM

TIMED 0.005 MINUTES

\begin{tabular}{|c|c|c|c|c|c|c|c|}
\hline $\begin{array}{l}\text { NUMHER OF } \\
\text { PHOTONS } \\
\text { STARTED } \\
16416\end{array}$ & $\begin{array}{l}\text { TOTAL } \\
\text { NUMGER OF } \\
\text { COLLISIONS } \\
\text { I!UB॰O }\end{array}$ & $\begin{array}{l}\text { RANDOM } \\
\text { NUMBEAS } \\
\text { OENEAATED } \\
1837675\end{array}$ & $\begin{array}{l}\text { TOTAL } \\
\text { UE IGHT } \\
\text { STAPTED } \\
1.6503 E \bullet 04\end{array}$ & $\begin{array}{l}\text { IOYAL } \\
\text { ENERGY } \\
\text { STARTEO } \\
\text { l.5SBTE+04 }\end{array}$ & $\begin{array}{l}\text { COLLISIONS } \\
\text { PER NHOTON } \\
\text { STAFTEU } \\
1.0096 E \cdot 01\end{array}$ & $\begin{array}{l}\text { TRACKS } \\
\text { PER PROTOH } \\
\text { STARTED } \\
5.569 \text { OE } 00\end{array}$ & $\begin{array}{l}\text { PHOTCNS } \\
\text { PROCESSED } \\
\text { PER MINUTE } \\
3.56 \bullet 2 E \bullet 03\end{array}$ \\
\hline $\begin{array}{l}\text { TOTAL } \\
\text { TAACKS } \\
\text { STAATED } \\
\text { PI\&10 }\end{array}$ & $\begin{array}{l}\text { LOSS TO } \\
\text { ENERGY } \\
\text { CUTOFF } \\
\end{array}$ & $\begin{array}{l}\text { LOSS To } \\
\text { TIHE } \\
\text { CUTOFF }\end{array}$ & $\begin{array}{l}\text { LOSS } \\
\text { TO } \\
\text { ESCAPE } \\
22400\end{array}$ & $\begin{array}{l}\text { LOSS } \\
\text { TO } \\
\text { CAPTURE } \\
16752\end{array}$ & $\begin{array}{l}\text { LOSS } \\
\text { TO } \\
\text { SPL1T IINO } \\
52190\end{array}$ & $\begin{array}{l}\text { Total } \\
\text { TaAcks } \\
\text { Lost } \\
\text { ?14in }\end{array}$ & \\
\hline $\begin{array}{l}\text { WE JGHT } \\
\text { STARTED } \\
\text { PER PHOTON } \\
\text { I.0OSAE•0O }\end{array}$ & $\begin{array}{l}\text { LOSS TO } \\
\text { ENEROY } \\
\text { CUTOFF } \\
\text { O. }\end{array}$ & $\begin{array}{l}\text { LOSS TO } \\
\text { TIME } \\
\text { CuTOFF } \\
\text { O. }\end{array}$ & $\begin{array}{l}\text { LOSS } \\
\text { TO } \\
\text { ESCAPE } \\
3.3906 E-01\end{array}$ & $\begin{array}{l}\text { LOSS } \\
\text { 10 } \\
\text { CAPTUAE } \\
\text { 6.OJUEE-01 }\end{array}$ & $\begin{array}{l}\text { UELGHT } \\
\text { LOST } \\
\text { PER PNDTON } \\
\text { I.0229E•.00 }\end{array}$ & & $\begin{array}{l}\text { PAIR } \\
\text { PAODUCTIOH } \\
\text { FER PHOTON } \\
9.4 \$ 79 E-O 3\end{array}$ \\
\hline $\begin{array}{l}\text { ENEAOY } \\
\text { STAPTED } \\
\text { PEA PHOTOH } \\
\text { P. } \$ 41 E \bullet 01\end{array}$ & $\begin{array}{l}\text { LOSS TO } \\
\text { ENEROT } \\
\text { CuTOFF } \\
0 .\end{array}$ & $\begin{array}{l}\text { Loss To } \\
\text { TIHE } \\
\text { CUTOFF } \\
\text { o. }\end{array}$ & $\begin{array}{l}\text { LoSS } \\
\text { to } \\
\text { ESCAPE } \\
4.4966 E-01\end{array}$ & $\begin{array}{l}\text { Loss } \\
\text { To } \\
\text { CAPTUAE } \\
\text {.O1 19E-02 }\end{array}$ & $\begin{array}{l}\text { LOSS } \\
\text { TOPAIR } \\
\text { PAODUET IOH } \\
7.1904 E-02\end{array}$ & $\begin{array}{l}\text { LOSS } \\
\text { TO } \\
\text { COMPTON } \\
3 . ? 33 \div E-O 1\end{array}$ & $\begin{array}{l}\text { EREAOY } \\
\text { YOST Pnoton } \\
\text { PER P1012-01 }\end{array}$ \\
\hline
\end{tabular}


total CELL DEPOSition data

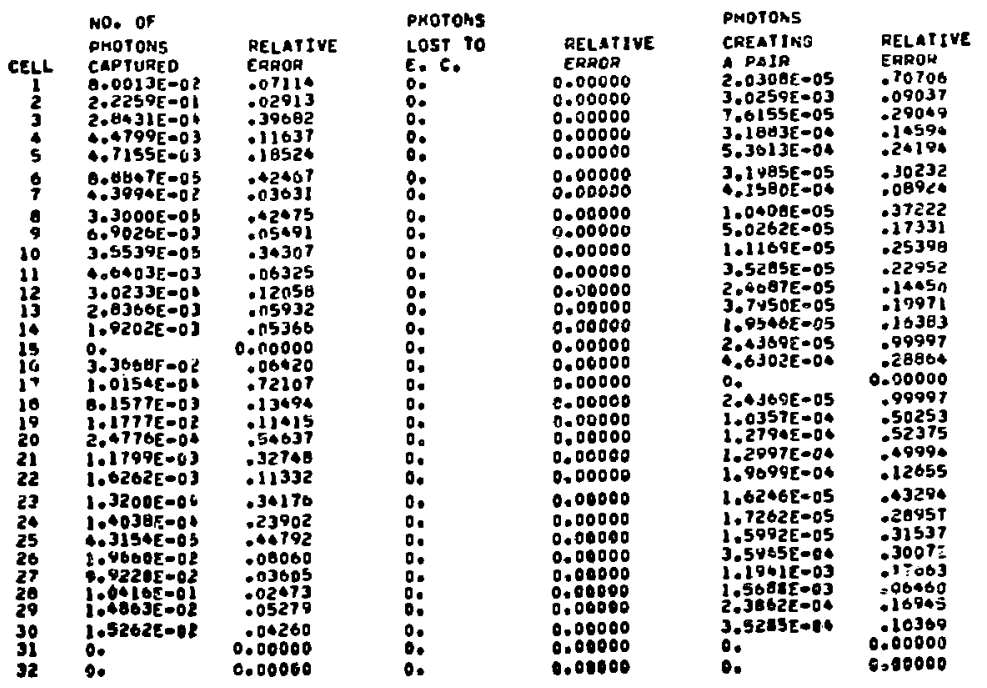

\begin{tabular}{|c|c|c|c|c|c|c|c|c|c|}
\hline $\begin{array}{c}\text { CELLL } \\
1 \\
2 \\
3 \\
5 \\
5 \\
6\end{array}$ & $\begin{array}{l}\text { ENERGT } \\
\text { LOST } \\
\text { TO CAPTUHE } \\
3.8119 E=01 \\
1.0617 E=0 ? \\
1.1620 E=04 \\
2.2643 E=0.1 \\
2.7657 E=04 \\
3.179 \text { SE }=0 .\end{array}$ & $\begin{array}{l}\text { RELATIVE } \\
\text { EAROA } \\
.07471 \\
.03111 \\
.38612 \\
.12327 \\
.19232 \\
.45401\end{array}$ & $\begin{array}{l}\text { ENEAOY LOST } \\
\text { TO ENEROY } \\
\text { cuTofF } \\
0: \\
0: \\
0: \\
0: \\
0 ; \\
0 .\end{array}$ & $\begin{array}{l}\text { RELATIVE } \\
\text { ERAOH } \\
0.00000 \\
0.00000 \\
0.00000 \\
0.00000 \\
0.00000 \\
0.00000\end{array}$ & $\begin{array}{l}\text { ENEWGY LOST } \\
\text { TO PAIR } \\
\text { PROUUCTION } \\
1.43 * 1 E=05 \\
2.3062 E=02 \\
6.1200 E=00 \\
2.5 \forall 30 E=03 \\
3.9158 E=03 \\
2.3203 E=06\end{array}$ & $\begin{array}{l}\text { RELA] IVE } \\
\text { ERROH } \\
.74803 \\
.10816 \\
.30639 \\
.16619 \\
.28195 \\
.37502\end{array}$ & $\begin{array}{l}\text { ENERGT } \\
\text { LOST } \\
\text { TO COMPTON } \\
4.624 \text { IE }=03 \\
1.0715 E=01 \\
\text { B.404E=03 } \\
3.4632 E=02 \\
.02646=02 \\
9.0944 E=03\end{array}$ & $\begin{array}{l}\text { RELATIVE } \\
\text { ERROA } \\
.12217 \\
.02858 \\
.051102 \\
.02729 \\
.00900 \\
.03611\end{array}$ & $\begin{array}{l}\text { TOTAL } \\
\text { ENEAGY } \\
\text { OEPOSITEO } \\
5.0543 E \div 03 \\
1.01 B 3 E=01 \\
9.0643 E=03 \\
3.7244 E=02 \\
6.6097 E=02 \\
9.3302 E=03\end{array}$ \\
\hline $\begin{array}{l}0 \\
1 \\
0 \\
9 \\
10 \\
11 \\
12 \\
13\end{array}$ & 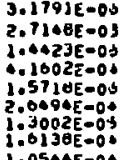 & $\begin{array}{l}.45401 \\
.03287 \\
.43227 \\
.05403 \\
.37012 \\
.16001 \\
.11319 \\
05742\end{array}$ & $\begin{array}{l}0 . \\
0: \\
0: \\
0 . \\
0: \\
0: \\
0: \\
0:\end{array}$ & $\begin{array}{l}0.00000 \\
0.00000 \\
0.00000 \\
0.00000 \\
0.00000 \\
0.00000 \\
0.00000 \\
0.00000\end{array}$ & $\begin{array}{l}2.3203 E=04 \\
3.1193 E=03 \\
6.4134 E=05 \\
3.3650 E=06 \\
8.5101 E=05 \\
2.9552 E=04 \\
1.9004 E=04 \\
3.2540 E=06\end{array}$ & $\begin{array}{l}.37502 \\
.10606 \\
.41207 \\
.20217 \\
.30012 \\
.26054 \\
.16542 \\
.23356\end{array}$ & $\begin{array}{l}9.0904 E=03 \\
1.1710 E=02 \\
2.1636 E=03 \\
2.2123 E=03 \\
1.0157 E=03 \\
1.3173 E=03 \\
3.0131 E=03 \\
9.3093 E=00 \\
0.7012 E=04\end{array}$ & $\begin{array}{l}.03611 \\
.02609 \\
.05414 \\
.05846 \\
.05557 \\
.07146 \\
.04475 \\
.07772 \\
.00909\end{array}$ & $\begin{array}{l}9.3302 E=03 \\
2.3612 E=02 \\
2.2491 E=03 \\
2.9649 E=03 \\
1.5025 E=03 \\
1.6777 E=03 \\
3.2242 E=03 \\
1.0183 E=03 \\
9.3726 E=00\end{array}$ \\
\hline $\begin{array}{l}14 \\
15 \\
16\end{array}$ & $\begin{array}{l}1.05 \times 4 E=04 \\
0 . \\
2.1096 E-0] \\
5.9928 E=06\end{array}$ & $\begin{array}{r}.05326 \\
0.00000 \\
.06410 \\
.81264\end{array}$ & $\begin{array}{l}\text { :: } \\
\text { :: }\end{array}$ & $\begin{array}{l}0.000000 \\
0.00000 \\
0.00000 \\
0.00000\end{array}$ & $\begin{array}{l}1.5 \angle 72 E-04 \\
1: 9<96 E=04 \\
3.0116 E=03 \\
0 .\end{array}$ & $\begin{array}{r}10517 \\
099097 \\
0: 36632 \\
0.00000\end{array}$ & $\begin{array}{l}0.7912 E=00 \\
1.1104 E=03 \\
1.6054 E=02 \\
3.6357=04\end{array}$ & $\begin{array}{r}.06969 \\
.16979 \\
.08429 \\
.37901\end{array}$ & $\begin{array}{l}9.3729 E=00 \\
1.3073 E=03 \\
2.2410 E-02 \\
3.8957 E=04\end{array}$ \\
\hline $\begin{array}{l}10 \\
19 \\
20 \\
21 \\
22 \\
23 \\
24 \\
25 \\
26 \\
27 \\
20 \\
29 \\
30\end{array}$ & 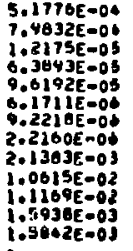 & $\begin{array}{l}.13590 \\
.11034 \\
.53270 \\
.33577 \\
112078 \\
.32812 \\
.23931 \\
03702 \\
.09011 \\
.04020 \\
.02501 \\
.05302 \\
.04020\end{array}$ & $\begin{array}{l}0 . \\
0: \\
0: \\
0: \\
0: \\
0: \\
0 . \\
0 . \\
0: \\
0 .\end{array}$ & $\begin{array}{l}0.00000 \\
0.00000 \\
0.00000 \\
0.00000 \\
0.00000 \\
0.00000 \\
0.00000 \\
0.00000 \\
0.00000 \\
0.00000 \\
0.00000 \\
0.00000 \\
0.00000\end{array}$ & $\begin{array}{l}1.0150 E=04 \\
5.5601 E=04 \\
0.2330 E=04 \\
1.1115 E=03 \\
1.4221 E=03 \\
1.0592 E=04 \\
1.0726 E=04 \\
1.2845 E=04 \\
2.0780 E=03 \\
9.0620 E=03 \\
1.1921 E=02 \\
1.6043 E=03 \\
2.3041 E=03\end{array}$ & $\begin{array}{l}.99997 \\
.51203 \\
.62091 \\
.58972 \\
.15620 \\
.07910 \\
.34420 \\
.31047 \\
.36064 \\
.21577 \\
.07502 \\
.22462 \\
.12655\end{array}$ & 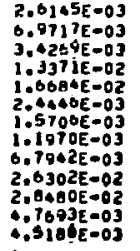 & $\begin{array}{l}.22130 \\
.13967 \\
117297 \\
.07453 \\
.02061 \\
.06959 \\
007032 \\
110620 \\
.15707 \\
.07737 \\
.02929 \\
.00217 \\
.06043\end{array}$ & 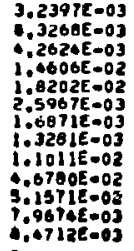 \\
\hline 32 & $\begin{array}{l}\text { O. } \\
\text { O. }\end{array}$ & $\begin{array}{l}0.00000 \\
0.00000\end{array}$ & O. & $\begin{array}{l}0.00000 \\
0.00000\end{array}$ & Q. & $\begin{array}{l}0.00000 \\
0.00000\end{array}$ & $\begin{array}{l}0 . \\
0 .\end{array}$ & $\begin{array}{l}0.00000 \\
0.00000\end{array}$ & 0. \\
\hline
\end{tabular}


NUMBEA OF PMOTOHS CROSSING SURFACE

TInE 0 .

COSINE 1.00001:000 $6.0000 E-01$

\begin{tabular}{|c|c|c|c|c|}
\hline $\begin{array}{l}\text { EMERGY } \\
5.0000 E=03 \\
1.0000 E-02 \\
1.0000 E-00 \\
5.0200 E+00 \\
1.4000 E-01\end{array}$ & $\begin{array}{r}\text { TO } \\
2.71539 E-03 \\
7.51391 E-03 \\
+2378 E=01 \\
2.38922 E-02 \\
2,43207 E=02\end{array}$ & $\begin{array}{l}\text { AEL. EAROR } \\
.66326 \\
.22109 \\
.11613 \\
.02814 \\
.02814 \\
.02952 \\
2\end{array}$ & $\begin{array}{l}\text { 0: To- } \\
\text { :-915aet-92 } \\
\text { :- } \\
\text { 0. }\end{array}$ & $\begin{array}{r}\text { REL. EAROR } \\
0.00000 \\
0.00000 \\
.07008 \\
0.00080 \\
0.00000\end{array}$ \\
\hline $\begin{array}{l}\text { ENERAT } \\
\text {, 0000E-03 }\end{array}$ & $0,-10$ & AEL: ERROR & 0 & REL: ERROR \\
\hline $\begin{array}{l}.0000 E=02 \\
.0000 E+00 \\
.0000 E=00 \\
.0000 E \bullet 01\end{array}$ & $\begin{array}{l}0 . \\
1.28570 E-02 \\
2.07159 E-03 \\
2.56209 E-03\end{array}$ & $\begin{array}{l}0.00000 \\
.06296 \\
.06087 \\
.06364\end{array}$ & $\begin{array}{l}0 . \\
0: \\
: 0 \\
0 .\end{array}$ & $\begin{array}{l}0.00000 \\
0.00000 \\
0.00000 \\
0.00000\end{array}$ \\
\hline
\end{tabular}

COSIME 0.0000E-OL $6.0000 E-0$ !

\begin{tabular}{|c|c|c|c|c|}
\hline $\begin{array}{l}\text { ENEROT } \\
.0000 E-03 \\
.0000 E-02 \\
0000 E \bullet 00 \\
0000 E \bullet 00 \\
.0000 E+01\end{array}$ & $\begin{array}{l}010 * \\
1.02771 E-03 \\
6,09236 E-03 \\
2,459362 E=03 \\
1,49527 E=02 \\
1,49628 E-02\end{array}$ & $\begin{array}{r}\text { REGE ERROR } \\
.577 \% 0 \\
.26482 \\
.02156 \\
.03604 \\
.03 A 20\end{array}$ & $\begin{array}{l}.10= \\
0.12315 E-04 \\
0 . \\
2.01000 E-02 \\
0 . \\
0 .\end{array}$ & $\begin{array}{r}\text { REL. ERROR } \\
.79053 \\
0.00000 \\
.068) \\
0.00000 \\
0.00000\end{array}$ \\
\hline 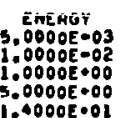 & 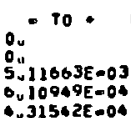 & $\begin{array}{c}\text { AEL : ERAOR } \\
0.00000 \\
0.00000 \\
.07338 \\
.12766\end{array}$ & $\begin{array}{l}\text { 0. } \\
0: \\
0: \\
0 .\end{array}$ & $\begin{array}{l}\text { TEL. ERROR } \\
0.00090 \\
0.00000 \\
0.00000 \\
0.00000 \\
0.00000\end{array}$ \\
\hline
\end{tabular}

I.4000E-OI $\quad .31542 E-04 \quad: 20521$

COSINE 6.0000L-0L $\quad .0000 E=01$

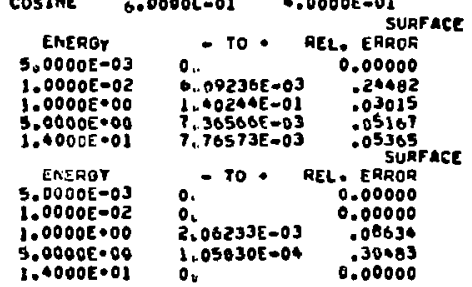

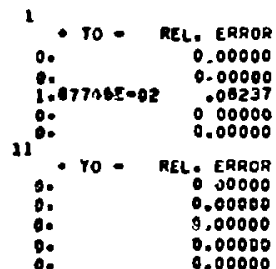

COSINE $\quad .0000 \mathrm{~K}=01 \quad 2.0000 E-01$

\begin{tabular}{|c|c|c|c|c|}
\hline $\begin{array}{l}\text { ENEROR } \\
0000 E=03 \\
0000 E=02 \\
00000 E+00 \\
.0000 E * 00\end{array}$ & 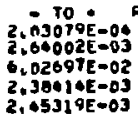 & $\begin{array}{l}\text { L. ERROQ } \\
.99997 \\
.42022 \\
.04005 \\
.09246 \\
.09262 \\
\text { SURF ACE }\end{array}$ & $\begin{array}{l}2.03079 E-00 \\
0: 305392-02 \\
1.30530 \\
11\end{array}$ & $\begin{array}{r}\text { AEL. ERROR } \\
79997 \\
0.00009 \\
.09732 \\
0.00000 \\
0.00000\end{array}$ \\
\hline $\begin{array}{l}\text { ENEROY } \\
.0000 E=03 \\
0000 E=02 \\
00000 E * 00 \\
00000 E \cdot 00 \\
.0000 E * 01\end{array}$ & $\begin{array}{l}0.10 * \\
0: \\
7.01120 E=06 \\
1.26386 E=05 \\
0 .\end{array}$ & $\begin{array}{r}\text { AEL. ERROR } \\
0.00000 \\
0.00000 \\
.09516 \\
.73039 \\
0.00000\end{array}$ & $\begin{array}{l}\text { oro } \\
0:{ }^{\circ} \\
\dot{0}\end{array}$ & $\begin{array}{l}\text { ELE ERROR } \\
0.50000 \\
0.00000 \\
0.00000 \\
0.00000 \\
0.00000\end{array}$ \\
\hline
\end{tabular}

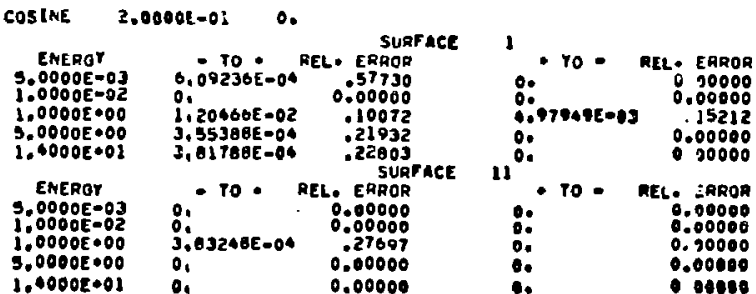

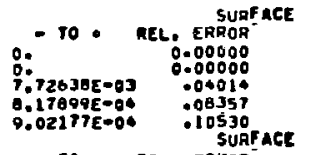

80

0. Suarac

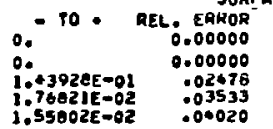
$10 \%$
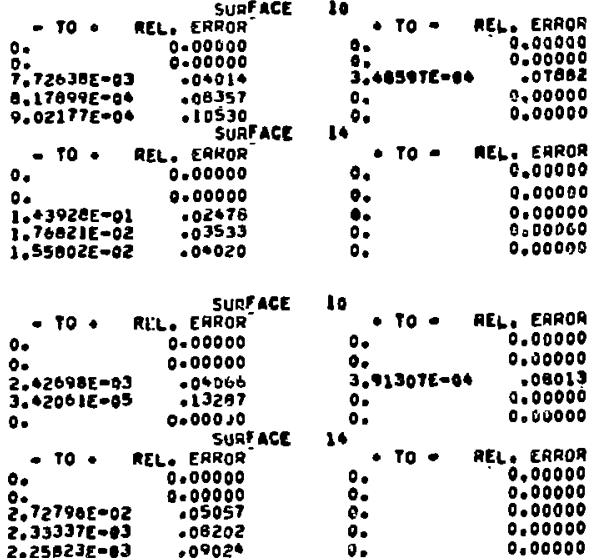

SURFACE

SURFACE 10

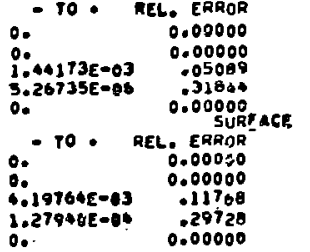

10 - TO - AEL, ERAOR

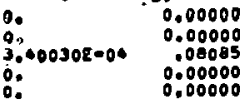

10

- TO - RLL, EARDA

$\begin{array}{ll}0 . & 0.00000 \\ 0 . & 0.00000 \\ 0 . & 0.00000\end{array}$

0.0 .00000
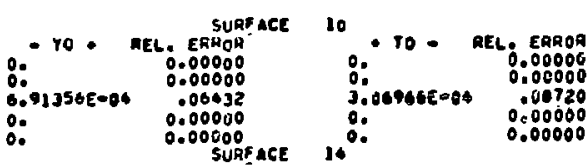

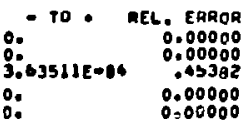

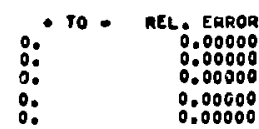

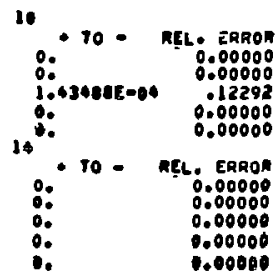


NUMBER FLUX IHTE ORATED OVEA SUAF ACE

$$
\begin{gathered}
\text { TIME O. } \\
\text { ENEREY } \\
5.0000 E-03 \\
1.0000=02 \\
1.0000 E=00 \\
5.00000000 \\
1.4000 E+03
\end{gathered}
$$

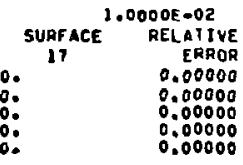

TIME $\quad 1.0000 E=02 \quad 1.0000 E-01$

\begin{tabular}{|c|c|c|}
\hline $\begin{array}{l}\text { ENEROY } \\
.0000 E=03 \\
1.0000 E=02 \\
1.0000 E=00 \\
5.0000 E+00 \\
1.0000 E+01\end{array}$ & $\begin{array}{l}\text { SURFACE } \\
\text { I7 } \\
0 . \\
0 . \\
7.12276 E=02 \\
0.32173 E=03 \\
2.74300 E=03\end{array}$ & $\begin{array}{r}\text { AELATIVE } \\
\text { ERROA } \\
0.00000 \\
0.00000 \\
.07031 \\
.06710 \\
.11593\end{array}$ \\
\hline
\end{tabular}

TIHE 1.0000E-02 1.0000E 000

\begin{tabular}{|c|c|c|}
\hline & FACE & RELAIIVE \\
\hline $\begin{array}{l}03 \\
02 \\
00 \\
00\end{array}$ & $\begin{array}{l}0 . \\
0.0 \\
3.12053 E-02 \\
0 . \\
0 .\end{array}$ & $\begin{array}{l}0.00000 \\
0.00000 \\
.10142 \\
0.00000 \\
0.00000\end{array}$ \\
\hline
\end{tabular}

TIME $\quad 1.0000 E 000 \quad 1.0000 \varepsilon \cdot 01$

\begin{tabular}{|c|c|c|}
\hline 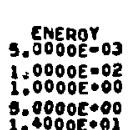 & $\begin{array}{l}\text { SURFACE } \\
0 . \\
0: \\
0: \\
0:\end{array}$ & $\begin{array}{r}\text { RELATIVE } \\
\text { ERFOR } \\
0.00000 \\
0.00000 \\
0.00000 \\
0.00000 \\
0.00000\end{array}$ \\
\hline
\end{tabular}

PATH LEKGTH/HOLUM:

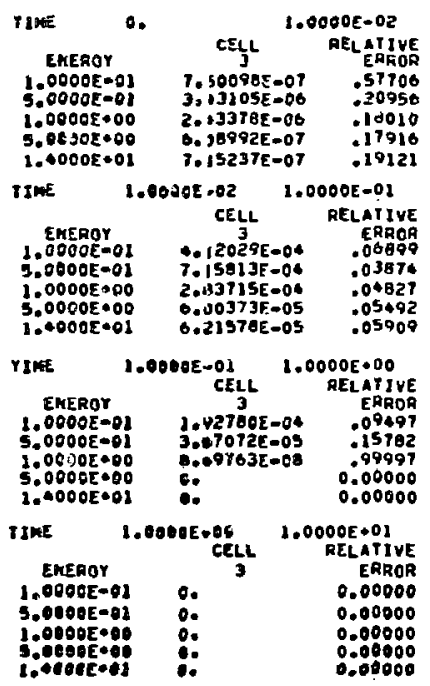

NUNGER FLUX AT UE'ECTOR

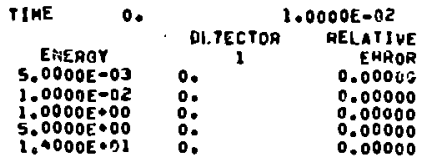

TIME 2,0000E $002 \quad 2,0000 E-01$

\begin{tabular}{|c|c|c|}
\hline $\begin{array}{c}\text { ENEAGY } \\
3.0000 E-03 \\
1.0000 E-02 \\
1.0000 E+00\end{array}$ & $\begin{array}{l}1 \\
0.4 \\
3.46101 E-29 \\
1.60796 E-05 \\
3.26125 E=06 \\
3.12916 E=06\end{array}$ & $\begin{array}{r}0.00 \\
.99\end{array}$ \\
\hline
\end{tabular}

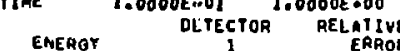

$3.0000 E-03$ O. 1 O.00000

$\begin{array}{lll}1.0000 E-02 & +0.35 \times 1 E-10 & .80352 \\ 1.0000 E+00 & 1.20952 E-05 & .03838\end{array}$

$\begin{array}{lll}1.0000 E * 00 & 1.28952 E=05 & .03838 \\ 1.0000 E * 00 & 1.04510 E=01 & .13690\end{array}$

$\begin{array}{lll}9.0000 E * 00 & 1.04520 E=01 & 0.13690 \\ 1.4000 E 01 & 0.00000\end{array}$

TIME $\quad 1.0000 E \times 00 \quad 1.0000 E+01$

ENEROY DLTECTOA AELATIVE

S.0000E-03 O. 0.00000

$1.0000 E=62 \quad \theta_{0} \quad 0.00000$

$\begin{array}{lll}1.0000 E+U S & 0 . & 0.00000 \\ .00000 * 00 & 0 . & 0.00000\end{array}$

$\begin{array}{lll}5.0000 E * 00 & 0 . & 0.00000 \\ 1.4000 E * 21 & 0 . & 0.00000\end{array}$

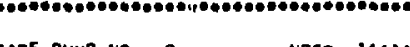




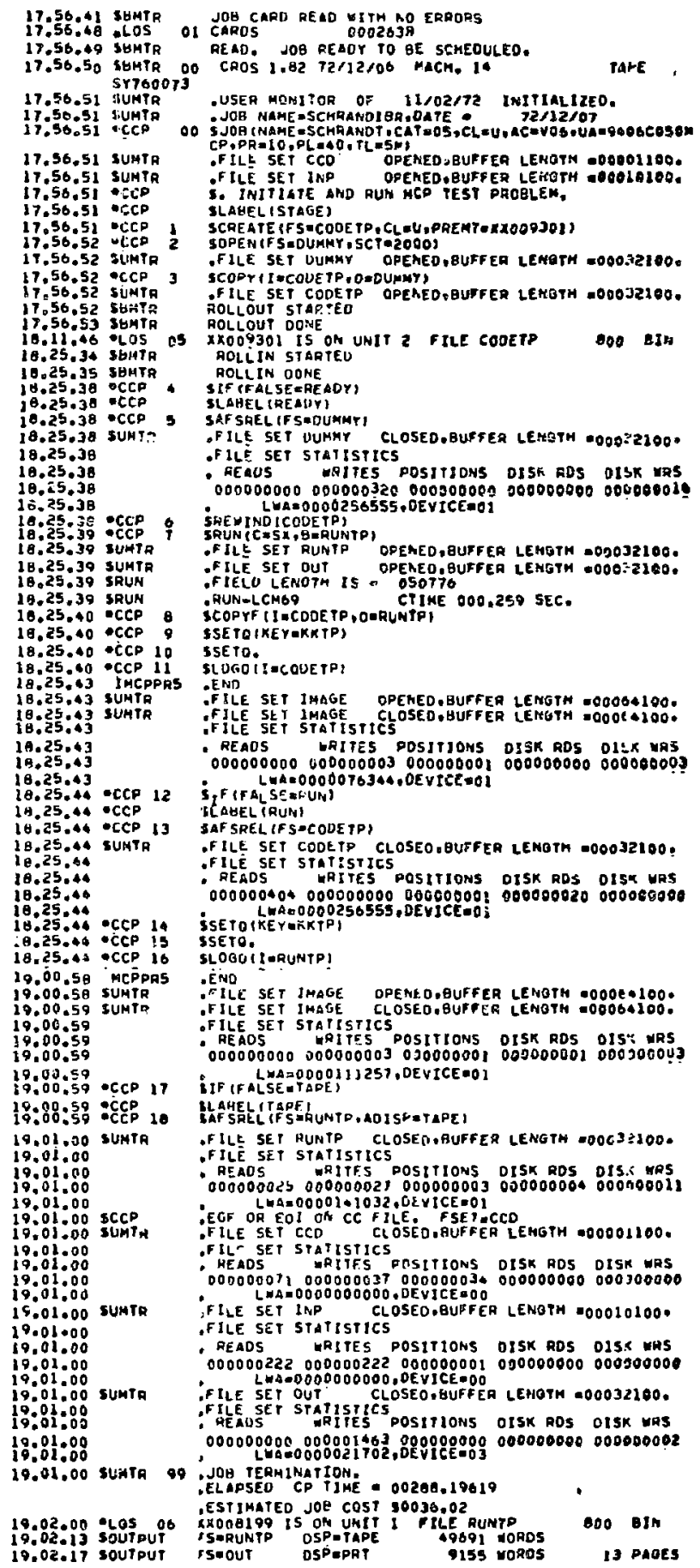

PILE COMPLETE SCIARANDIBA 1 


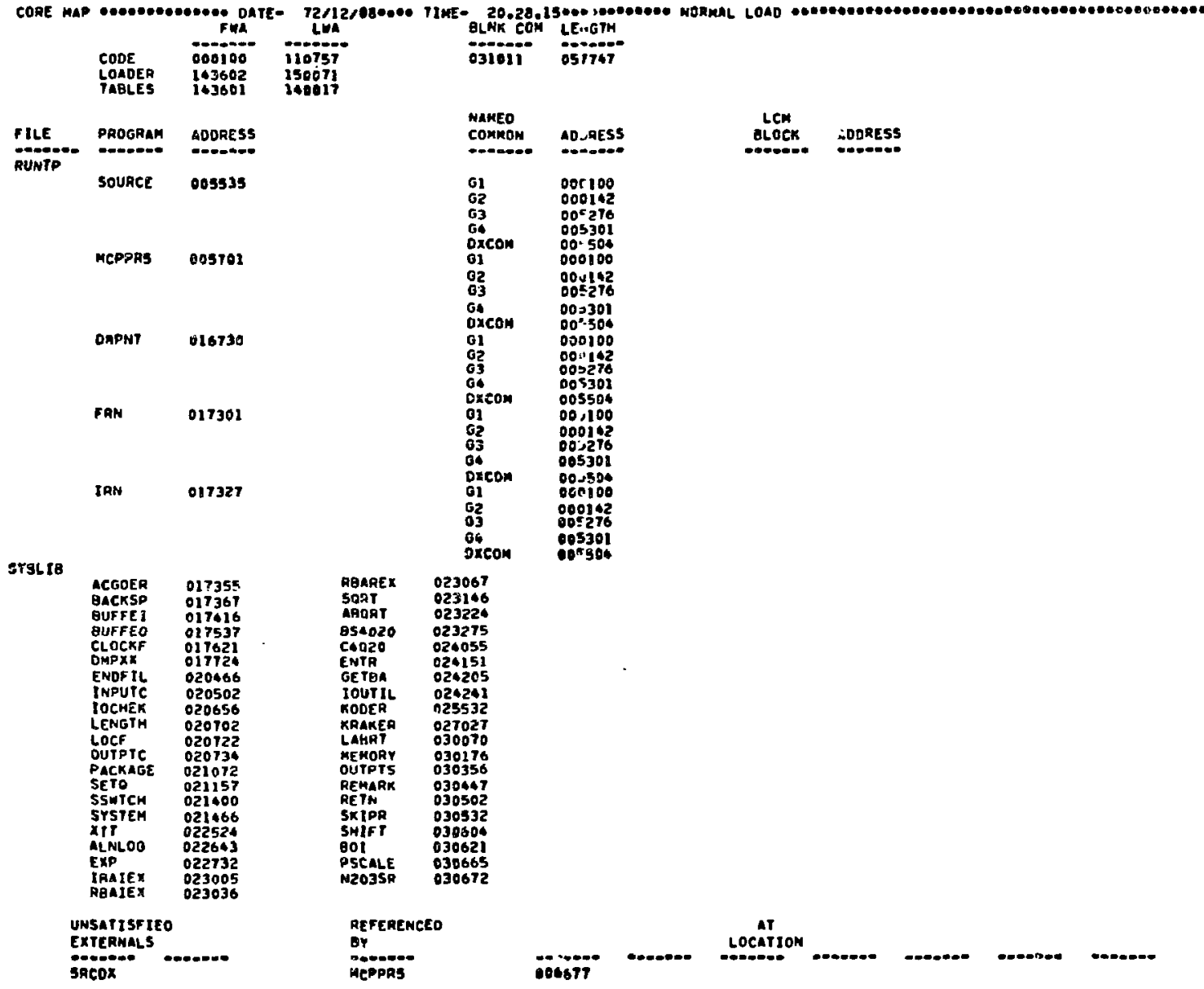

MCP IEST PAOQLEM

\begin{tabular}{|c|c|c|c|c|c|c|c|c|}
\hline \multirow[t]{2}{*}{ SOURCE Ko: } & \multirow[t]{2}{*}{$\begin{array}{l}\text { TIME CUTOFF } \\
1.0000 E \cdot 02\end{array}$} & $\begin{array}{l}\text { ENEROT EUTOFF } \\
1.0000 E-03\end{array}$ & $\begin{array}{l}\text { RUN TIKE } \\
\leftrightarrow, 90 \text { Q }\end{array}$ & \multicolumn{2}{|c|}{$\begin{array}{l}\text { D.p. CYCLE } \\
50000\end{array}$} & $\begin{array}{l}\text { Oukp Crele } \\
\text { SOS00 }\end{array}$ & \multirow[t]{2}{*}{$\underset{-0}{\text { DUMP NO. }}$} & \multirow[t]{2}{*}{$\begin{array}{c}\text { CUTOFF CYCLE } \\
-0\end{array}$} \\
\hline & & & TIME: & - Wlnutes & & & & \\
\hline $\begin{array}{l}\text { NUARER OT } \\
\text { PMOTONS } \\
\text { STARTEO } \\
33217\end{array}$ & $\begin{array}{l}\text { TOTAL } \\
\text { NUMEE or } \\
\text { COLLI5IONS } \\
365325\end{array}$ & $\begin{array}{l}\text { RANDOH } \\
\text { MUMBERS } \\
\text { OENERATEO } \\
3740703\end{array}$ & $\begin{array}{l}\text { TOTAL } \\
\text { UETOHT } \\
\text { 5TAPTEO } \\
3.3410 E \bullet 04\end{array}$ & $\begin{array}{l}\text { TOTAL } \\
\text { ENEROY } \\
\text { STARTEO } \\
3.250 \text {. }\end{array}$ & $\begin{array}{l}\text { COLL ISIONS } \\
\text { PER PHOTON } \\
\text { STANTEO } \\
1.099 \text {.OI }\end{array}$ & $\begin{array}{l}\text { TRACKS } \\
\text { PER PMOTOK } \\
\text { STARTEO } \\
\text { S.54GEE } 00\end{array}$ & $\begin{array}{l}\text { PHOTONS } \\
\text { PAOCESSEO } \\
\text { PFA MTNUTE } \\
3.5526 E 003\end{array}$ & \\
\hline $\begin{array}{l}\text { TOTAL } \\
\text { TRACKS } \\
\text { STARTEO } \\
\text { IOARAB }\end{array}$ & $\begin{array}{l}\text { LOSS TO } \\
\text { ENERGY } \\
\text { CuTOFF }\end{array}$ & $\begin{array}{l}\text { Loss ro } \\
\text { TlHE } \\
\text { cutafi }\end{array}$ & $\begin{array}{l}\text { LoSS } \\
\text { to } \\
\text { ESCAPE } \\
\text { \$4SUS }\end{array}$ & $\begin{array}{l}\text { Loss } \\
\text { To } \\
\text { CAPTURE } \\
34312\end{array}$ & $\begin{array}{l}\text { Loss } \\
\text { To } \\
\text { se } \\
105391 \text { INA } \\
10539\end{array}$ & $\begin{array}{l}\text { roTAL } \\
\text { TRACKS } \\
\text { LOST } \\
\text { 104248 }\end{array}$ & & \\
\hline $\begin{array}{l}\text { WELANT } \\
\text { STARTEO } \\
\text { PER PMDTON } \\
\text { I.0061E } \bullet 00\end{array}$ & $\begin{array}{l}\text { LOSS TO } \\
\text { ENERGY } \\
\text { CUTOFF } \\
0 .\end{array}$ & $\begin{array}{l}\text { Loss to } \\
\text { TiHe } \\
\text { cutof } \\
\text { o. }\end{array}$ & $\begin{array}{l}\text { Loss } \\
\text { To } \\
\text { ESCAPE } \\
3.3946 E-01\end{array}$ & $\begin{array}{l}\text { Ooss } \\
\text { fo } \\
\text { CAPTuRE } \\
6.8302 t-01\end{array}$ & $\begin{array}{l}\text { MEIGMT } \\
\text { LOST } \\
\text { PER PMOTON } \\
\text { l.0225E•.00 }\end{array}$ & & 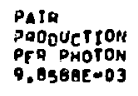 & \\
\hline $\begin{array}{l}\text { ENERGT } \\
\text { STAATEO } \\
\text { OEA OHOTON } \\
\text { 9.405SE-O1 }\end{array}$ & $\begin{array}{l}\text { LOSS TO } \\
\text { ENERG } \\
\text { CuTOFF } \\
\text { O. }\end{array}$ & $\begin{array}{l}\text { Loss to } \\
\text { tinz } \\
\text { cutof } \\
\text { o. }\end{array}$ & $\begin{array}{l}\text { Loss } \\
\text { io } \\
\text { ESCAPE } \\
\text { W.15SBSE-01 }\end{array}$ & $\begin{array}{l}\text { LOSS } \\
\text { To } \\
\text { CAPTURE } \\
\text { D. OOODS-02 }\end{array}$ & $\begin{array}{l}\text { Loss } \\
\text { To: AIT } \\
\text { PAOOUCTION } \\
\text { T.43SoE }=02\end{array}$ & $\begin{array}{l}\text { Loss } \\
\text { To } \\
\text { conproH } \\
\text { jo6930t-ol }\end{array}$ & $\begin{array}{l}\text { ENEAGY } \\
\text { LAST } \\
\text { PTA DMOTON } \\
\text { P.4SSIE-01 }\end{array}$ & \\
\hline
\end{tabular}


roTAL EELL OEJOSitsnt CATA

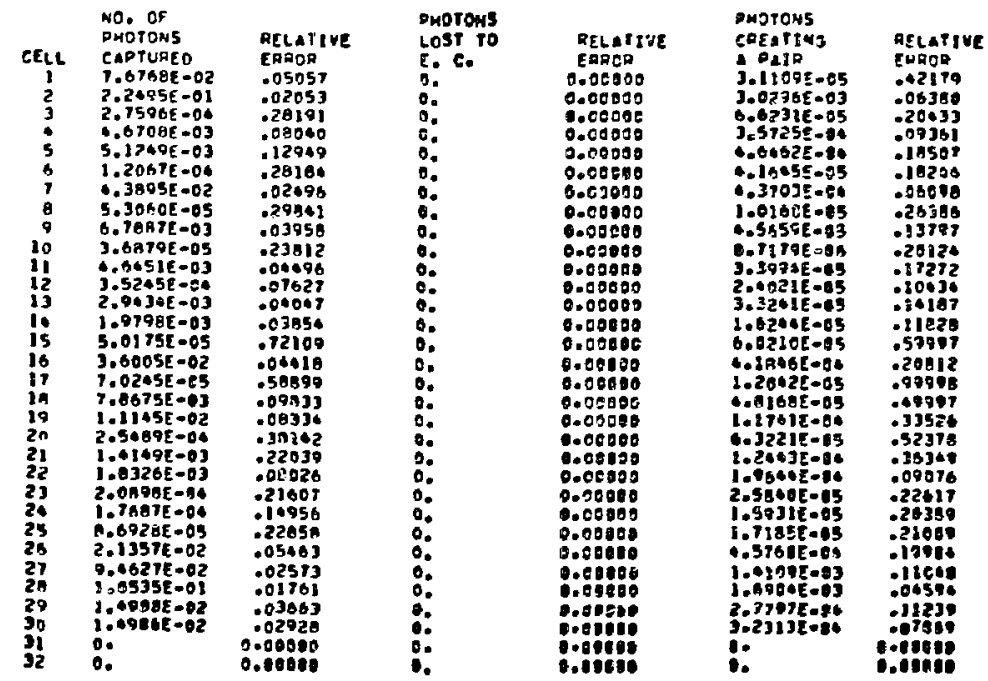

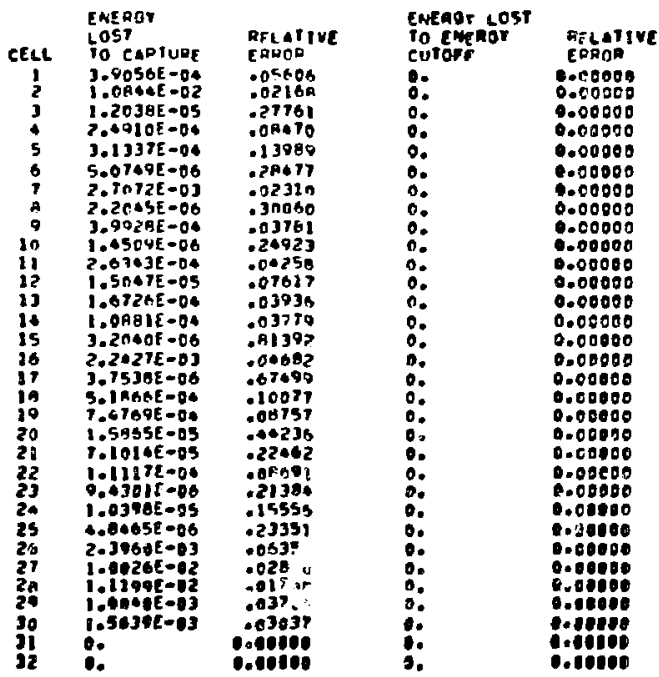

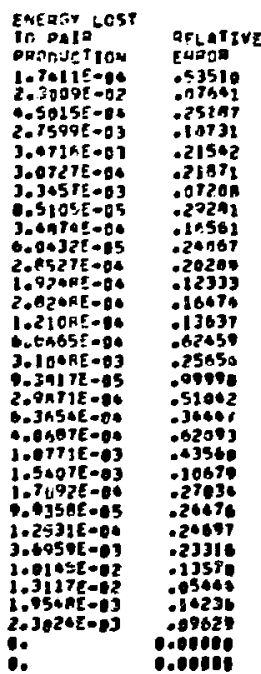
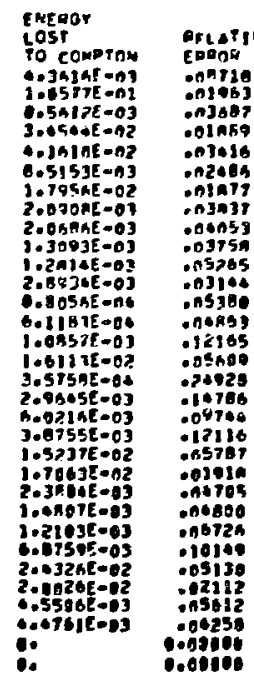

retal. Digosition $4+974,1 ;-113$ $0,0>30 E \rightarrow \infty$ 0,5 79se-02 ?.Mrat $\rightarrow$ t? ?.00nst $\rightarrow$ - I? ?.liafe-aj 2.01A7E-0 i.jrize-o? $3.10105-03$ $1.3301 E-03$ $0.01725=06$ M. irssi-03

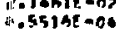
I. 7ntog-03

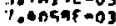
$4.2012 E-0]$ $1.63155-02$ $1.87252-62$ C.ShBne - 03 1.500450 .03 1. JaOSE-0J 1.206AE-02 -.*Are-02 S.Jjoze-02 $0.3424 E-01$ :. 
muncze of enoroms caossing suarace

ine $0.0000 \mathrm{C} .02$

cosint l.0pactao b.0000e-as

\begin{tabular}{|c|c|c|}
\hline 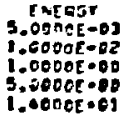 & 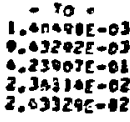 & $\left\{\begin{array}{l}\text { EEL } \\
.04020 \\
.74050 \\
.01116 \\
.01057 \\
.02960\end{array}\right.$ \\
\hline $\begin{array}{c}\text { ENEOST } \\
\text { S.0000E-03 } \\
1.0000 F-02 \\
1.0000 E-94 \\
5.00005-09 \\
1.0000 E-01\end{array}$ & 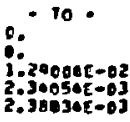 & 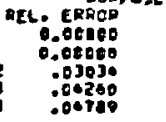 \\
\hline
\end{tabular}

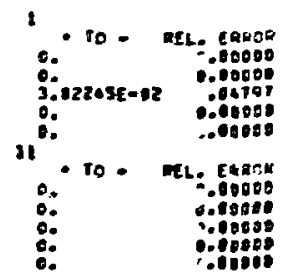

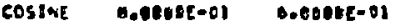

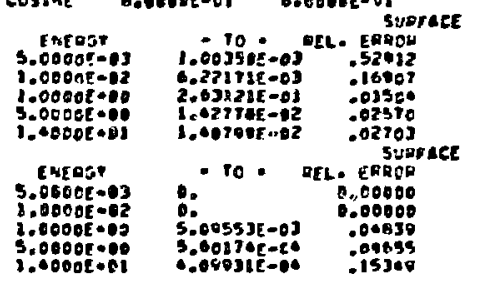

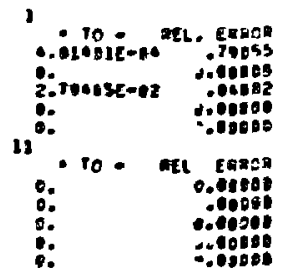

cosine conect-os o.goter-es

\begin{tabular}{|c|c|c|}
\hline 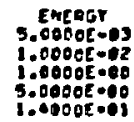 & 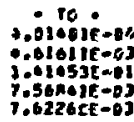 & $\begin{array}{r}\text { REL }=\text { cropop } \\
.79095 \\
.19670 \\
.02090 \\
.03015 \\
.03010\end{array}$ \\
\hline 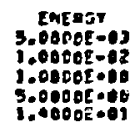 & 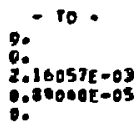 & 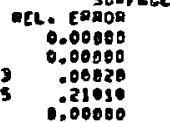 \\
\hline
\end{tabular}

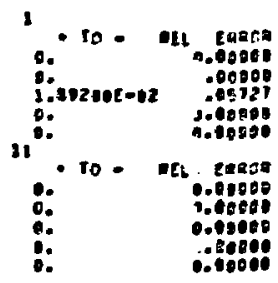

COSINE $4.0000 E-01 \quad 2.0000 E-0$ g
ENERST

\begin{tabular}{|c|c|c|}
\hline 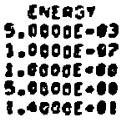 & 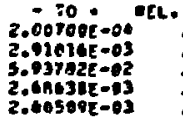 & $\begin{array}{l}\text { congo } \\
.70700 \\
.27795 \\
.03230 \\
.08305 \\
.00308 \\
5 \text { 5ugace }\end{array}$ \\
\hline
\end{tabular}

EnEogr

$5.0000 E-03$

$1.0000 E-62$
$1.0000 E=90$

$1.0000 E=00$
$.0000 E+00$

$\therefore 0000001$

$\operatorname{cosinE} 2,001 \theta t-010$.

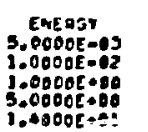

EMERG

$5,0000 \mathrm{E}-03$
$1.0000 \mathrm{C}-03$

1.0000E-12

1.djentegs

i. 4000 ees

\begin{abstract}
- 10. aet. carar
\end{abstract}
0. 10. Met. Carop

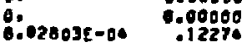

0.5207te-jer $\begin{array}{r}.55052 \\ 0.00000\end{array}$

OAt-01 0.

- TO - DEL. CADOD

$\begin{array}{ll}3.01051 E-04 & .51732 \\ 3.01051 E-04 & .09098\end{array}$

I.17Rize-02 -07200

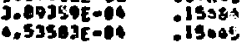

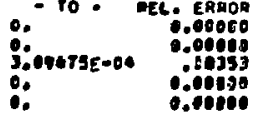

- ro - eet sugraee
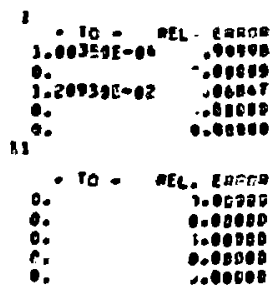

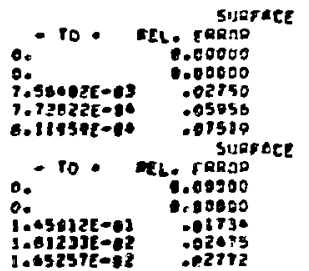

- seorace

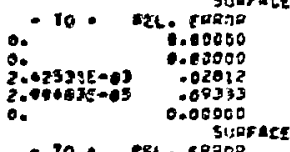

- 10. net. fagor

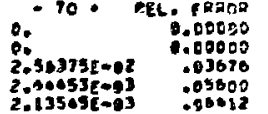
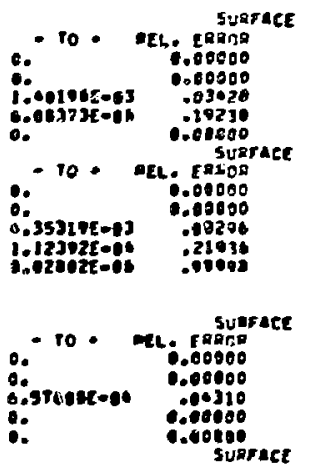

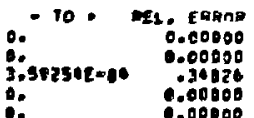

- to - Atr. gargagace

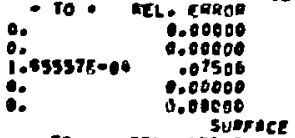

- to - nelo cence

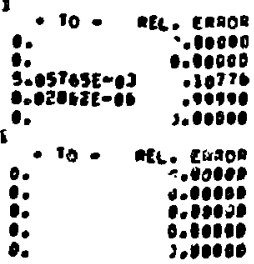

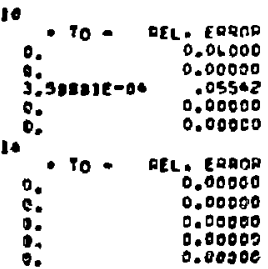

111

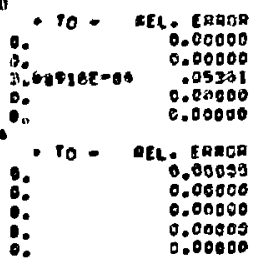

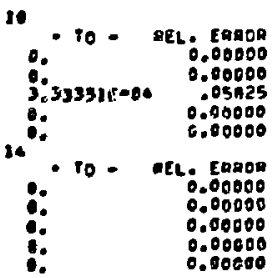

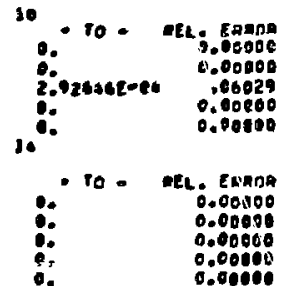

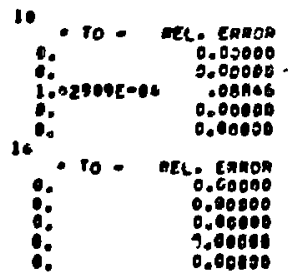




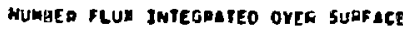

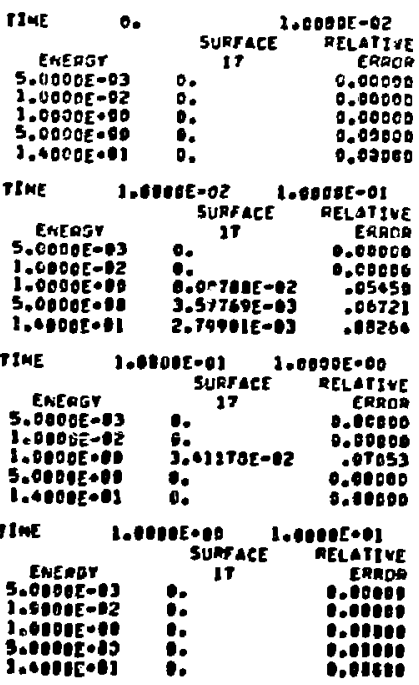

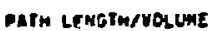

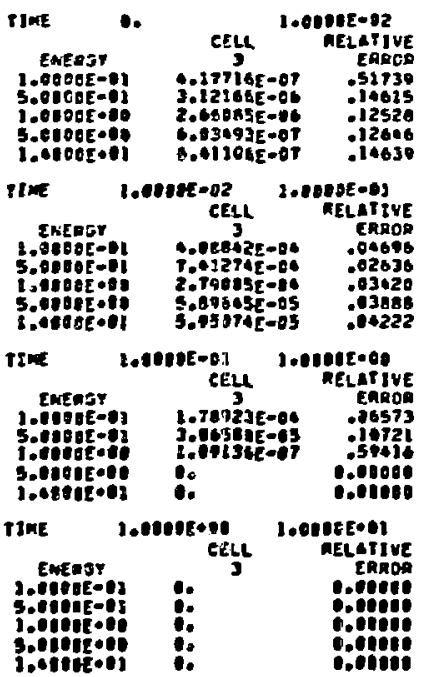

MUAEP rLUX AT DETECTOA

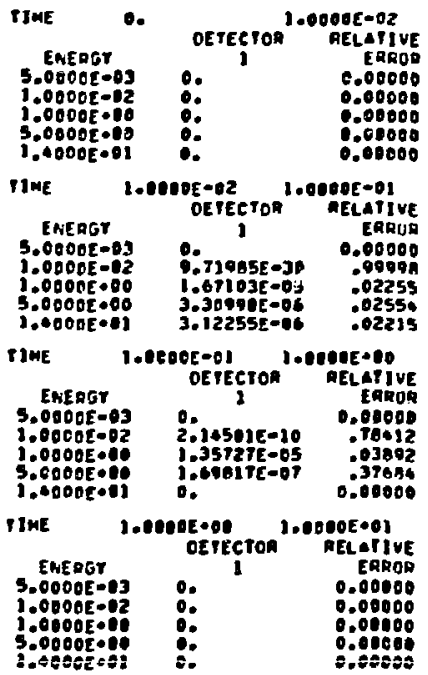

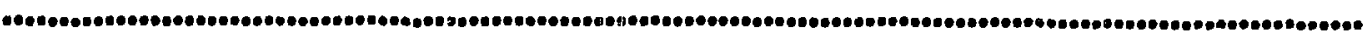




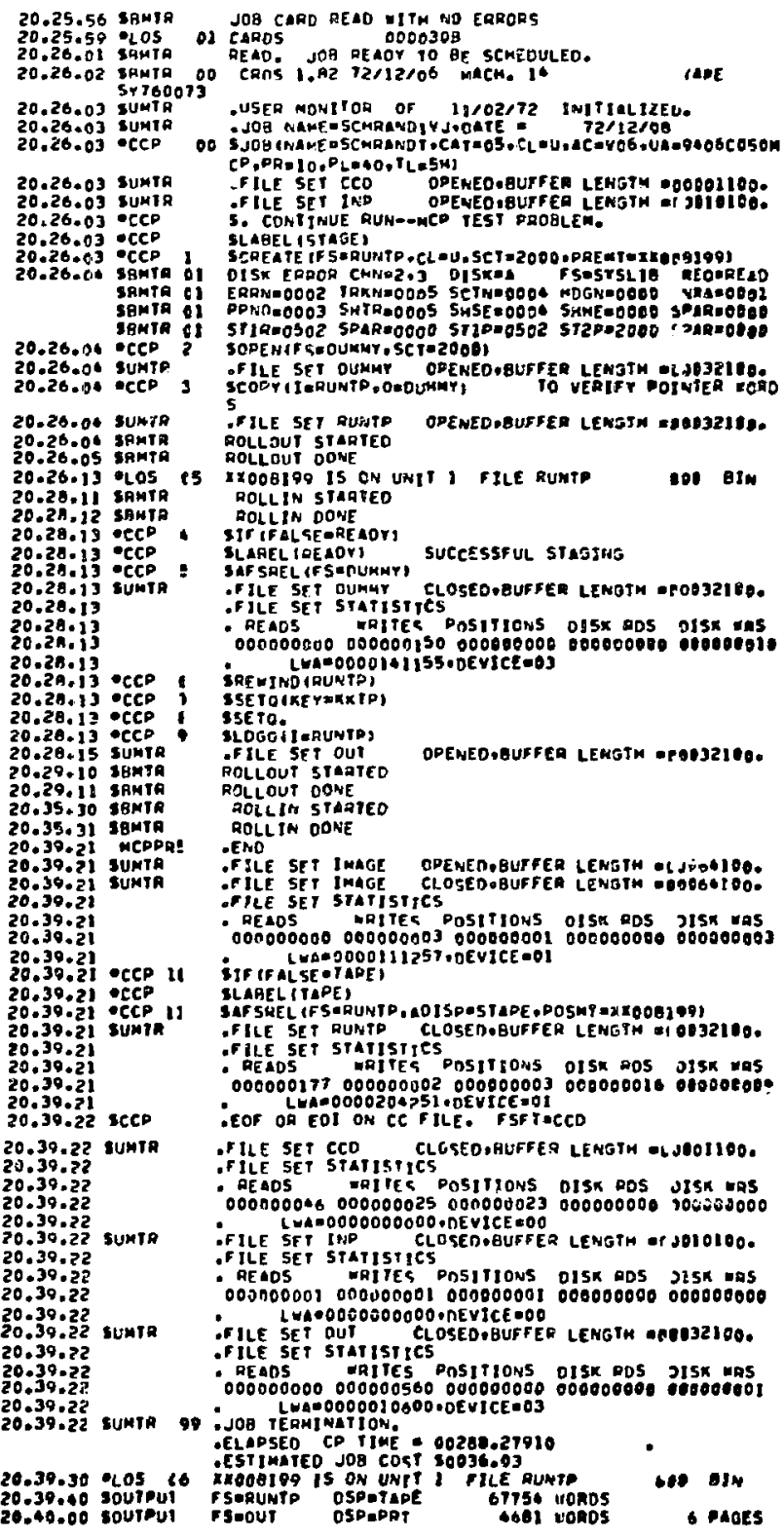

- ile complete scmaakoiyj 2

ALT. 533(260) 